\title{
AVALIAÇÃO DA INCIDÊNCIA DA DOENÇA E ESTIMATIVA DE DANOS OCASIONADOS PELO CARVÃO (Ustilago scitaminea Sydow) EM VARIEDADES DE CANA-DE-AÇÚCAR
}

MARCOS VIRGILIO CASAGRANDE

Dissertação apresentada à Escola Superior de Agricultura "Luiz de Queiroz", Universidade de São Paulo, para obtenção do título de Mestre em Agronomia, Área de Concentração: Fitopatologia.

\author{
PIR A C I C A B A \\ Estado de São Paulo - Brasil \\ Fevereiro - 1998
}


Dados Internacionais de Catalogação na Publicação (CIP) DIVISÃo DE BIBLIOTECA E DOCUMENTAÇÃO - Campus "Luiz de Queiroz"/USP

C.asagrande, Marcos Virgilio

Avaliaçao da incidência da doença e estimativa de danos ocasionados pelo carvão

(Ustilago scitaminea Sydow) em variedades de cana-de-açúcar / Marcos Virgilio

Casagrande. - - Piracicaba, 1998.

$86 \mathrm{p}$.

Dissertaçāo (mestrado) - - Escola Superior de Agricultura Luiz de Queiroz, 1998.

Bibliografia.

1. Cana-de-açúcar 2. Carvão 3. Clone 4. Doença 5. Variedade I. Título 


\title{
AVALIAÇÃO DA INCIDÊNCIA DA DOENÇA E ESTIMATIVA DE DANOS OCASIONADOS PELO CARVÃO (Ustilago scitaminea Sydow) EM VARIEDADES DE CANA-DE-AÇÚCAR
}

\section{MARCOS VIRGILIO CASAGRANDE \\ Engenheiro Agrônomo}

Orientadora: Profa. Dra. LILIAN AMORIM

\begin{abstract}
Dissertação apresentada à Escola Superior de Agricultura "Luiz de Queiroz", Universidade de São Paulo, para obtenção do título de Mestre em Agronomia, Área de Concentração: Fitopatologia.
\end{abstract}

\author{
PIRACICABA \\ Estado de São Paulo - Brasil \\ Fevereiro - 1998
}


Dedico este trabalho aos meus queridos pais Antonio e Clotilde, que através de atos me ensinaram o real significado das palavras amor $e$ dedicação. 


\section{AGRADECIMENTOS}

Gostaria de expressar meus agradecimentos

À Cooperativa Central dos Produtores de Cana, Açúcar e Álcool do Estado de São Paulo - COPERSUCAR - pela autorização para o desenvolvimento do experimento e utilização dos dados;

À minha orientadora, Profa. Dra. Lilian Amorim, pelo suporte prestado durante toda a elaboração do presente trabalho. Agradeço as horas contínuas que dedicou, melhorando não apenas a qualidade deste trabalho, mas também a minha formação acadêmica e profissional;

Ao $\mathrm{Eng}^{\circ} \mathrm{Agr}^{\circ} \mathrm{Dr}$. Alvaro Sanguino, chefe da Seção de Fitopatologia da Copersucar, amigo, colaborador, e responsável direto pela minha opção pela Fitopatologia, além de grande incentivador da pesquisa aplicada à cultura da cana-de-açúcar;

Ao Eng ${ }^{\circ} \mathrm{Agr}^{\circ} \mathrm{Dr}$. William Lee Burnquist, gerente da Divisão de Fitotecnia da Copersucar, pela autorização para realização do curso e pela colaboração oferecida, principalmente em relação à utilização de recursos necessários;

Ao meu amigo Eng ${ }^{\circ} \mathrm{Agr}^{\circ} \mathrm{Dr}$. Caio Octavio Nogueira Cardoso, pelo grande apoio e incentivo para a realização deste trabalho;

Aos meus amigos Arnaldo José Raizer, Rubens L. C. Braga Jr. e Antonio Carlos Fernandes, pelo auxílio na análise dos dados e na editoração do texto;

À minha amiga Iraneuda Maria Cardinalli Ferraz, bibliotecária da Copersucar, pela pronta disposição na localização dos trabalhos literários; 
À minha amiga Eliete Ferezini, estagiária da Seção de Fitopatologia da Copersucar, pela valiosa ajuda na conferência dos dados experimentais;

Aos técnicos agrícolas da Seção de Fitopatologia da Copersucar (Ataliba Franceschi Piedade, José Aparecido Dizeró, José Deodato P. de Campos e Sidney Donizetti Ducatti), que participaram diretamente nos trabalhos de campo. 


\section{SUMÁRIO}

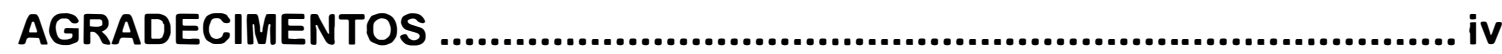

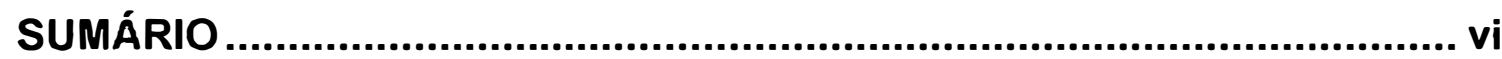

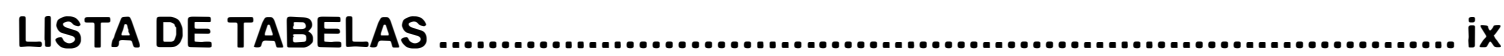

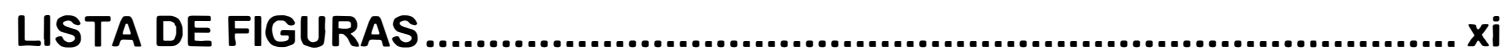

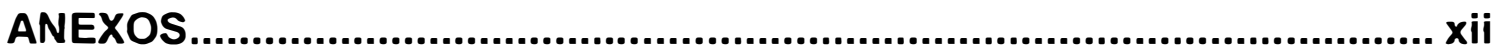

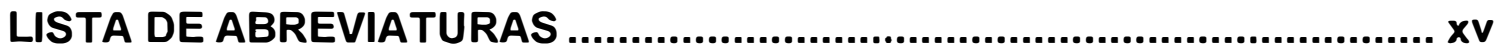

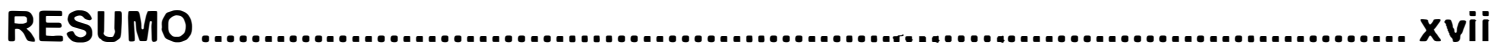

SUMMARY

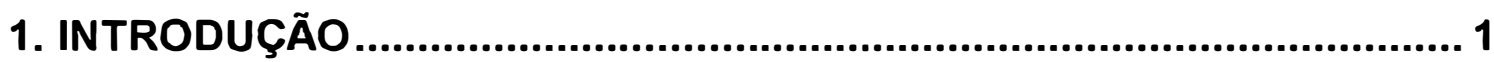

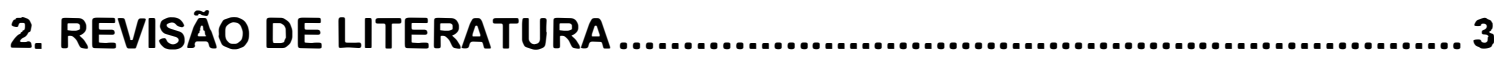

2.1. Histórico

2.2. Importância econômica .....................................................................................4

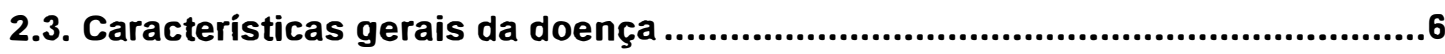

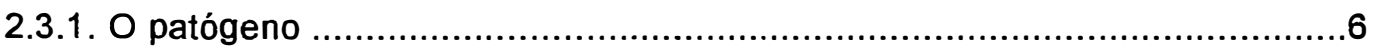

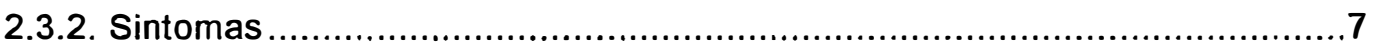


2.3.3. Ciclo da doença 8

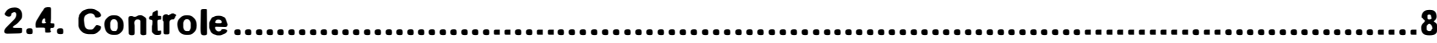

2.4.1. Obtenção de variedades resistentes ..................................................

2.4.2. Obtenção de mudas sadias .................................................................11

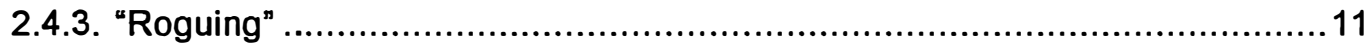

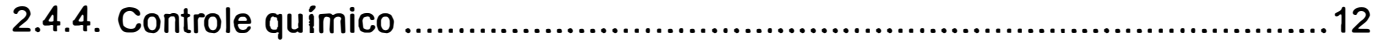

2.5. Critérios para a quantificação da doença .....................................................13

2.6. Correlação entre a incidência da doença e os niveis de dano .........................16

3. MATERIAL E MÉTODOS ............................................................... 18

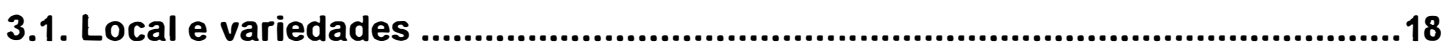

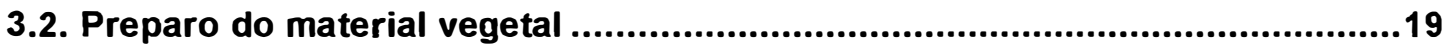

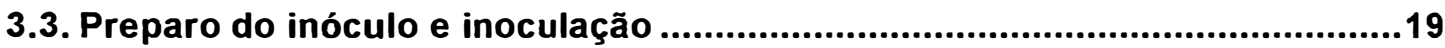

3.4. Formação de mudas para o plantio.............................................................19

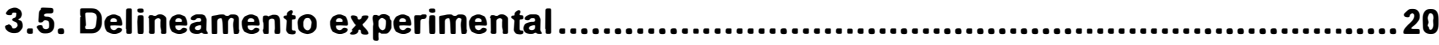

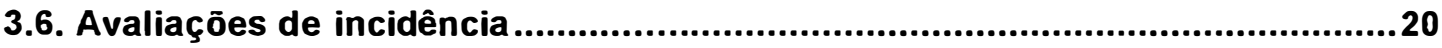

3.7. Análise de variáveis para quantificar a incidência da doença.......................22

3.7.1. Valor médio da incidência acumulada de doença (VM) ...........................24

3.7.2. Área abaixo da curva de progresso da doença (AUDPC) ........................24

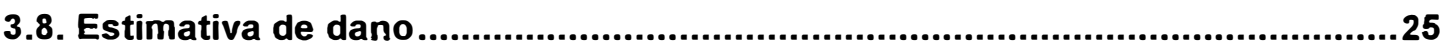

4. RESULTADOS E DISCUSSÃO .................................................. 27

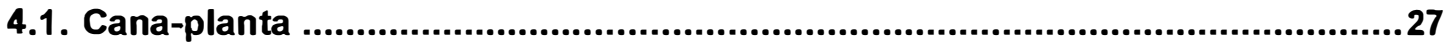

4.1.1. Avaliação da incidência de doença...............................................27

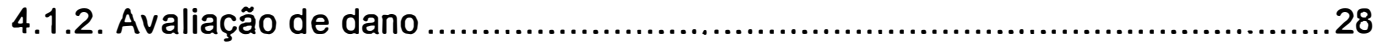




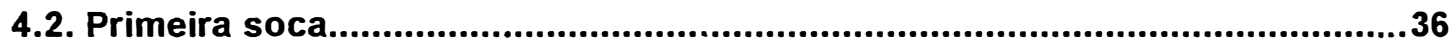

4.2.1 Avaliação da incidência de doença...................................................... 36

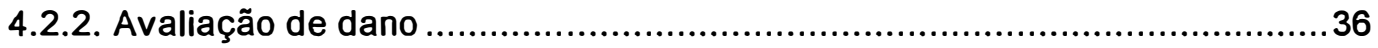

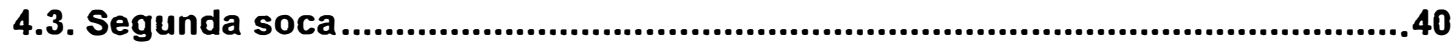

4.3.1. Avaliação da incidência de doença .......................................................40

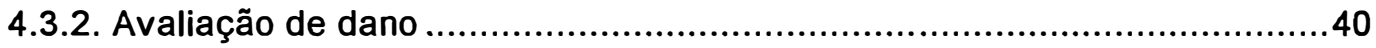

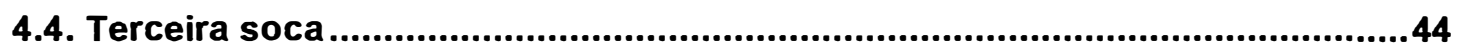

4.4.1. Avaliação da incidência de doença...................................................44

4.4.2. Avaliação de dano ............................................................... 44

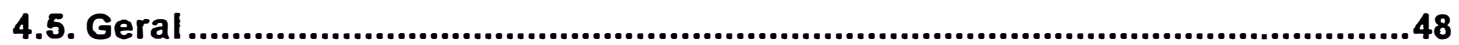

4.5.1 Avaliação da intensidade de doença.............................................48

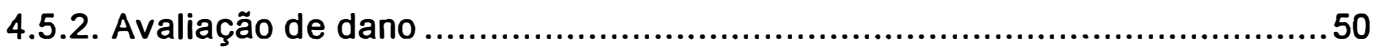

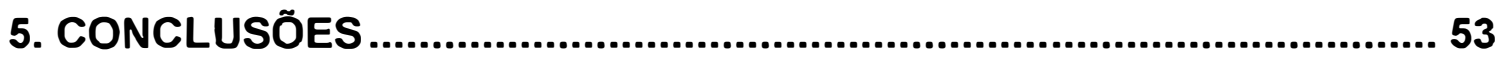

6. REFERÊNCIAS BIBLIOGRÁFICAS ............................................ 54 


\section{LISTA DE TABELAS}

Tabela 1 - Genitores, países de origem e reação ao carvão das variedades de cana-de-açúcar utilizadas no experimento..............................18

Tabela 2 - Cronograma de atividades realizadas no experimento.

Tabela 3 - Comparação entre a média de incidência acumulada de doença (valor médio (VM) e área abaixo da curva de progresso da doença (AUDPC)) para quatro variáveis de incidência de doença (porcentagem acumulada de: touceiras doentes por parcela (PATDP), perfilhos doentes por touceiras (PAPDT), perfilhos doentes por parcela (PAPDP), touceiras mortas por parcela (PATMP)), obtidas na cana-planta.

Tabela 4 - Danos provocados pelo carvão na cana-planta.

Tabela 5 - Comparação entre a média de incidência acumulada e não acumulada de doença (valor médio (VM) e área abaixo da curva de progresso da doença (AUDPC)) para sete variáveis de incidência de doença (porcentagem acumulada de: touceiras doentes por parcela (PATDP), perfilhos doentes por touceiras (PAPDT), perfilhos doentes por parcela (PAPDP), touceiras mortas por parcela (PATMP) e porcentagem não acumulada de: touceiras doentes por parcela (PNTDP), perfilhos doentes por touceiras (PNPDT), perfilhos doentes por parcela (PNPDP)), obtidas na primeira soca.

Tabela 6 - Danos provocados pelo carvão na primeira soca. 38

Tabela 7 - Comparação entre a média de incidência acumulada e não acumulada de doença (valor médio (VM) e área abaixo da curva de progresso da doença (AUDPC)) para sete variáveis de incidência de doença (porcentagem acumulada de: touceiras doentes por parcela (PATDP), perfilhos doentes por touceiras 
(PAPDT), perfilhos doentes por parcela (PAPDP), touceiras mortas por parcela (PATMP) e porcentagem não acumulada de: touceiras doentes por parcela (PNTDP), perfilhos doentes por touceiras (PNPDT), perfilhos doentes por parcela (PNPDP)), obtidas na segunda soca.

Tabela 8 - Danos provocados pelo carvão na segunda soca.

Tabela 9 - Comparação entre a média de incidência acumulada e não acumulada de doença (valor médio (VM) e área abaixo da curva de progresso da doença (AUDPC)) para sete variáveis de incidência de doença (porcentagem acumulada de: touceiras doentes por parcela (PATDP), perfilhos doentes por touceiras (PAPDT), perfilhos doentes por parcela (PAPDP), touceiras mortas por parcela (PATMP) e porcentagem não acumulada de: touceiras doentes por parcela (PNTDP), perfilhos doentes por touceiras (PNPDT), perfilhos doentes por parcela (PNPDP)), obtidas na terceira soca.

Tabela 10 - Danos provocados pelo carvão na terceira soca.

Tabela 11 - Valores observados para as variáveis percentuais acumulativas: perfilhos doentes por parcela (PAPDP), perfilhos doentes por touceira (PAPDT), touceiras doentes por parcela (PATDP) e touceiras mortas por parcela (PATMP) nos quatro ciclos da cultura e variações observadas entre os ciclos.

Tabela 12 - Classificação das seis variáveis que apresentaram os menores valores para PTRAT(\%) e CV(\%) nos quatro ciclos da cultura.

Tabela 13 - Comparação dos valores de PTRAT(\%) e CV(\%) obtidos para a variável de porcentagem acumulada de touceiras doentes por parcela (PATDP) durante os quatro ciclos da cultura. Os valores representam médias de um ou mais ciclos.

Tabela 14 - Valores da porcentagem acumulada de touceiras doentes $(\operatorname{ATD}(\%))$ e da redução média de peso das touceiras devida ao carvão (Dano(\%)) nos quatro ciclos da cultura, para as 18 variedades testadas. 


\section{LISTA DE FIGURAS}

Figura 1 - Curva de progresso da doença em função de quatro variáveis de incidência do carvão, porcentagem acumulada de: perfilhos doentes por parcela (PAPDP), perfilhos doentes por touceira (PAPDT), touceiras doentes por parcela (PATDP) e touceiras mortas por parcela (PATMP), nos quatro ciclos da cultura.

Figura 2 - Relação entre valores da área abaixo da curva de progresso da doença (AUDPC) para três variáveis de incidência percentual acumulada de doença (perfilhos doentes por touceira (PAPDT), perfilhos doentes por parcela (PAPDP) e touceiras doentes por parcela (PATDP)) e o dano (Dano(\%)), na cana-planta.

Figura 3 - Relação entre valores da área abaixo da curva de progresso da doença (AUDPC) para três variáveis de incidência percentual acumulada de doença (perfilhos doentes por touceira (PAPDT), perfilhos doentes por parcela (PAPDP) e touceiras doentes por parcela (PATDP)) e o dano (Dano(\%)), na primeira soca.

Figura 4 - Relação entre valores da área abaixo da curva de progresso da doença (AUDPC) para três variáveis de incidência percentual acumulada de doença (perfilhos doentes por touceira (PAPDT), perfilhos doentes por parcela (PAPDP) e touceiras doentes por parcela (PATDP)) e o dano (Dano(\%)), na segunda soca.

Figura 5 - Relação entre valores da área abaixo da curva de progresso da doença (AUDPC) para três variáveis de incidência percentual acumulada de doença (perfilhos doentes por touceira (PAPDT), perfilhos doentes por parcela (PAPDP) e touceiras doentes por parcela (PATDP)) e o dano (Dano(\%)), na terceira soca. 


\section{ANEXOS}

Anexo 1- Mapa de plantio do experimento no campo.

Anexo 2 - Porcentagem acumulada de perfilhos doentes por parcela (PAPDP) para as 18 variedades do experimento, durante a cana-planta.

Anexo 3 - Porcentagem acumulada de perfilhos doentes por touceira (PAPDT) para as 18 variedades do experimento, durante a cana-planta.

Anexo 4 - Porcentagem acumulada de touceiras doentes por parcela (PATDP) para as 18 variedades do experimento, durante a cana-planta.

Anexo 5 - Porcentagem acumulada de touceiras mortas por parcela (PATMP) para as 18 variedades do experimento, durante a cana-planta.

Anexo 6 - Porcentagem acumulada de perfilhos doentes por parcela (PAPDP) para as 18 variedades do experimento, durante a primeira soca.

Anexo 7 - Porcentagem acumulada de perfilhos doentes por touceira (PAPDT) para as 18 variedades do experimento, durante a primeira soca.

Anexo 8- Porcentagem acumulada de touceiras doentes por parcela (PATDP) para as 18 variedades do experimento, durante a primeira soca.

Anexo 9 - Porcentagem acumulada de touceiras mortas por parcela (PATMP) para as 18 variedades do experimento, durante a primeira soca. 
Anexo 10 - Porcentagem não acumulada de perfilhos doentes por parcela (PNPDP) para as 18 variedades do experimento, durante a primeira soca.

Anexo 11 - Porcentagem não acumulada de perfilhos doentes por touceira (PNPDT) para as 18 variedades do experimento, durante a primeira soca.

Anexo 12 - Porcentagem não acumulada de touceiras doentes por parcela (PNTDP) para as 18 variedades do experimento, durante a primeira soca.

Anexo 13 - Porcentagem acumulada de perfilhos doentes por parcela (PAPDP) para as 18 variedades do experimento, durante a segunda soca.

Anexo 14 - Porcentagem acumulada de perfilhos doentes por touceira (PAPDT) para as 18 variedades do experimento, durante a segunda soca.

Anexo 15 - Porcentagem acumulada de touceiras doentes por parcela (PATDP) para as 18 variedades do experimento, durante a segunda soca.

Anexo 16 - Porcentagem acumulada de touceiras mortas por parcela (PATMP) para as 18 variedades do experimento, durante a segunda soca.

Anexo 17 - Porcentagem não acumulada de perfilhos doentes por parcela (PNPDP) para as 18 variedades do experimento, durante a segunda soca

Anexo 18 - Porcentagem não acumulada de perfilhos doentes por touceira (PNPDT) para as 18 variedades do experimento, durante a segunda soca

Anexo 19 - Porcentagem não acumulada de touceiras doentes por parcela (PNTDP) para as 18 variedades do experimento, durante a segunda soca.

Anexo 20 - Porcentagem acumulada de perfilhos doentes por parcela (PAPDP) para as 18 variedades do experimento, durante a terceira soca. 
Anexo 21 - Porcentagem acumulada de perfilhos doentes por touceira (PAPDT) para as 18 variedades do experimento, durante a terceira soca.

Anexo 22 - Porcentagem acumulada de touceiras doentes por parcela (PATDP) para as 18 variedades do experimento, durante a terceira soca.

Anexo 23 - Porcentagem acumulada de touceiras mortas por parcela (PATMP) para as 18 variedades do experimento, durante a terceira soca.

Anexo 24 - Porcentagem não acumulada de perfilhos doentes por parcela (PNPDP) para as 18 variedades do experimento, durante a terceira soca.

Anexo 25 - Porcentagem não acumulada de perfilhos doentes por touceira (PNPDT) para as 18 variedades do experimento, durante a terceira soca.

Anexo 26 - Porcentagem não acumulada de touceiras doentes por parcela (PNTDP) para as 18 variedades do experimento, durante a terceira soca. 


\section{LISTA DE ABREVIATURAS}

ATD(\%) - Porcentagem de plantas doentes

AUDPC - Área abaixo da curva de progresso da doença

CV(\%) - Coeficiente de variação

Dano(\%) - Redução de produção provocada pelo carvão

Dif(\%) - Diferença média de peso entre touceiras sadias e doentes

FTRAT - Distribuição F de Snedecor

ID(\%) - Índice de redução da produção para cada $1 \%$ de touceiras infectadas

NMPI - Número médio de perfilhos industrializáveis por touceira

NNPD - Número de perfilhos doentes surgidos após o levantamento anterior

$\mathrm{NPI}$ - Número de perfilhos industrializáveis

NTPD - Número total de perfilhos doentes

NTPS - Número total de perfilhos sadios

NVPD - Número total de perfilhos doentes visiveis em cada levantamento

NVPS - Número total de perfilhos sadios visiveis em cada levantamento

P - Cana-planta

PAPDP - Porcentagem acumulada de perfilhos doentes por parcela

PAPDT - Porcentagem acumulada de perfilhos doentes por touceira

PATDP - Porcentagem acumulada de touceiras doentes por parcela

PATMP - Porcentagem acumulada de touceiras mortas por parcela

$\mathrm{PM}$ - Peso $(\mathrm{Kg})$ médio das touceiras 
PNPDP - Porcentagem não acumulada de perfilhos doentes por parcela

PNPDT - Porcentagem não acumulada de perfilhos doentes por touceira

PNTDP - Porcentagem não acumulada de touceiras doentes por parcela

PPI - Peso dos perfilhos industrializáveis

PTRAT(\%) - Probabilidade porcentual de erro ao admitir que existe pelo menos

um contraste significativo entre as variáveis para as 18 variedades do experimento

S1 - Primeira soca

S2 - Segunda soca

S3 - Terceira soca 


\title{
AVALIAÇÃO DA INCIDÊNCIA DA DOENÇA E ESTIMATIVA DE DANOS OCASIONADOS PELO CARVÃO (Ustilago scitaminea Sydow) EM VARIEDADES DE CANA-DE-AÇÚCAR
}

\author{
Autor: Marcos Virgilio Casagrande
}

Orientadora: Profa. Dra. Lilian Amorim

\section{RESUMO}

O carvão da cana-de-açúcar, causado pelo fungo Ustilago scitaminea, é uma doença de fácil diagnóstico, devido à facilidade de observação de seu principal sinal, o "chicote". Na maioria das regiões do mundo onde se cultiva a cana-de-açúcar, observa-se alternância de periodos de incidência epidêmica com outros onde a doença raramente é notada. De maneira geral, os surtos epidêmicos ocorrem quando as variedades de cultivo predominante apresentam suscetibilidade ao patógeno.

Se por um lado o diagnóstico da doença é universal, o mesmo não ocorre com a quantificação de sua incidência que varia grandemente entre as instituições de pesquisa, dificultando o intercâmbio de informações. O mesmo é observado em relação aos estudos visando determinar a redução de produção provocada pela doença. Enquanto alguns autores apontam reduções da ordem de $100 \%$, outros afirmam que as mesmas inexistem ou são despreziveis. Esta controvérsia explica o fato do carvão ser considerado a principal doença da canade-açúcar em diversos paises, enquanto, em outros, sua importância é secundária.

Neste sentido, o presente trabalho, propôs: a) comparar a evolução da doença em termos de perfilhos e touceiras doentes, estabelecendo qual a melhor 
variável para determinar o nivel de resistência das variedades; b) avaliar a redução de produção que o carvão pode causar em variedades de cana-deaçúcar, devido à redução no peso das touceiras

O experimento foi instalado com 18 variedades de cana-de-açúcar inoculadas artificialmente com o patógeno, em delineamento de blocos casualizados, com quatro repetições. Os levantamentos foram realizados durante quatro ciclos consecutivos da cultura. A incidência da doença foi avaliada em função das porcentagens acumuladas e não acumuladas de: perfilhos doentes por parcela, perfilhos doentes por touceira e touceiras doentes por parcela, além da porcentagem acumulada de touceiras mortas por parcela. A área sob a curva de progresso da doença (AUDPC) para as porcentagens acumuladas de: perfilhos doentes por parcela (PAPDP), perfilhos doentes por touceira (PAPDT) e touceiras doentes por parcela (PATDP) foram relacionadas com 0 dano (Dano(\%)) provocado pela doença.

Os resultados demonstraram que a determinação da incidência da doença através da AUDPC da porcentagem acumulada de touceiras doentes por parcela (PATDP) permitiu uma melhor separação das variedades em função de suas reações ao patógeno. Os valores de AUDPC determinados pelas porcentagens acumuladas de perfilhos doentes por parcela (PAPDP) e perfilhos doentes por touceira (PAPDT) foram similares ao longo dos ciclos, sendo sempre menores que os valores de PATDP.

A redução no número de perfilhos industrializáveis foi o maior efeito provocado pelo carvão nas plantas infectadas. Foi possivel estabelecer altas correlações entre PAPDP, PAPDT e PATDP e o dano provocado pela doença, quando as mesmas foram realizadas em função da AUDPC. Ao longo dos quatro ciclos da cultura, PATDP foi a variável que apresentou os maiores valores de coeficiente de determinação $\left(R^{2}\right)$ quando relacionada ao dano, variando de 0,97 a 0,99 .

Embora a reação ao carvão seja uma característica varietal, de maneira geral ocorreu uma redução no peso das touceiras de $0,86 \%$ para cada $1 \%$ de AUDPC para touceiras afetadas nos quatro ciclos da cultura. 
Devido à melhor separação das variedades em função de sua reação ao carvão, à melhor correlação com o dano provocado pelo patógeno e à diminuição na mão de obra empregada durante os levantamentos, a incidência de carvão em clones e variedades de cana-de-açúcar deve ser quantificada por avaliações de porcentagem de plantas doentes. 


\title{
DISEASE INCIDENCE ASSESSMENT AND DAMAGE ESTIMATION DUE TO SMUT (Ustilago scitaminea Sydow) IN SUGARCANE VARIETIES
}

\author{
Author: Marcos Virgilio Casagrande
}

Adviser: Profa. Dra. Lilian Amorim

\section{SUMMARY}

Sugarcane smut disease caused by the fungus Ustilago scitaminea Sydow is a ailment relatively easy to diagnostic due to the unequivocal observation of its main symptom, the whip. In most regions of the world where sugarcane is grown a regular alternation of the disease is observed with periods of epidemic incidence and periods where the infected plants are rarely seen. In most cases the epidemic incidence occurs when the predominant cultivated varieties are susceptible to the pathogen.

While the disease diagnostic is adopted extensively, the assessment of the incidence is not. A considerable variability of the disease reported among the research institutions exists, and this fact restrain the interchange of results. The same is observed in studies to determinate the yield reduction on account of the disease. While some authors related up to $100 \%$ of reduction in production, others warrant that the same are not real or insignificant. This controversial fact explains why smut is considered the principal sugarcane disease in many countries, while in others, its value is secondary.

Consequently, the present paper proposed: a) to compare the disease evolution by diseased stalks and stools, to establish the best variable to 
determinate the varieties level resistance; b) to evaluate the yield reduction by smut in sugarcane varieties due to the stools reduction weight.

The experiment was installed using eighteen sugarcane varieties that were inoculated artificially with the pathogen in delineated hazard blocks with four replications. The assessment was accomplished throughout four consecutive culture cultivation cycles. The disease incidence was evaluated by examining the percentage of accumulated and non accumulated of: diseased stalks per plot, diseased stalks per stool and diseased stools per plot, besides the accumulated percentage of dead stools per plot. The areas under disease progress curves (AUDPC) to the accumulated percentage of diseased stalks per plot (PAPDP), diseased stalks per stool (PAPDT) and diseased stools per plot (PATDP) were related with the damage due to the disease.

The results showed that the disease incidence determination by AUDPC of accumulated percentage of diseased stools per plot (PATDP) permitted a better separation of the varieties according to individual pathogen reaction. The AUDPC values established by the accumulated percentages of diseased stalks per plot (PAPDP) and the diseased stalks per stool (PAPDT) were similar during the four cycles, although always smaller than that of the PATDP values.

The reduction in the number of useful stalks was the major effect caused by smut in the infected plants. It was possible to established high correlation among PAPDP, PAPDT and PATDP and the damage caused by the disease, when they were determined in function of the AUDPC. Throughout four cultivation cycles, PATDP was the variable that showed higher determination coefficient value $\left(R^{2}\right)$ related to damage, in the rang of 0.97 and 0.99 .

Although smut reaction is regarded as a variety characteristic, in general a reduction of $0.86 \%$ in the weight of the stool to each unit of AUDPC was observed for the affected stools during the four cycles of cultivation.

Considering data such as, better variety classification according to the smut reaction, better correlation with the damage caused by the pathogen and the reduction man work employed during the assessments, smut incidence in 
sugarcane varieties and clones should be quantified by evaluations of the percentage of diseased plants. 


\section{INTRODUÇÃO}

Em épocas remotas, quando o homem iniciou a agricultura, as variedades de cana-de-açúcar mais doces, tenras e produtivas eram preferidas para o plantio. Mais recentemente, com a expansão das áreas cultivadas, além da riqueza em açúcar e produtividade, o homem teve de selecionar materiais resistentes a pragas e doenças. Assim, em Java no século XIX, teve início o programa de melhoramento da cana-de-açúcar, visando basicamente introduzir genes de resistência a doenças em novas variedades através de hibridação, dirigida por cruzamentos.

O histórico da cultura da cana-de-açúcar no Brasil e no mundo mostra que o principal fator na substituição de variedades tem sido a ocorrência epidêmica de doenças e neste contexto o carvão ocupa um papel de destaque. No geral, a história da doença caracteriza-se por surtos ocasionais, seguidos de longos períodos onde volta a ser endêmica. A ocorrência de epidemias sempre está intimamente relacionada com o nivel de suscetibilidade das variedades cultivadas.

Embora o diagnóstico do carvão seja extremamente fácil e universal, a quantificação da doença é bastante variável, em função dos diferentes critérios usados em sua determinação. Esta variabilidade dificulta o intercâmbio de informações e deixa dúvidas quanto ao melhor método a ser adotado para determinar sua intensidade, usada para determinar o nível de resistência de cultivares.

Muitos trabalhos relatam os prejuízos causados por Ustilago scitaminea na cultura da cana-de-açúcar, havendo variação nos níveis de dano encontrados. 
Trabalhos recentes, mais quantitativos, estão de acordo no que se refere aos prejuízos causados pelo carvão (Whittle \& Walker, 1982; Ferreira \& Comstock, 1982; Sanguino et al., 1984; Glaz et al., 1985; Irey, 1986; Casagrande \& Sanguino, 1994), situando os danos na faixa de 0,27 a $1,17 \%$ em peso da cana, para cada aumento de $1 \%$ no nível de infecção. Outros prejuízos diretos citados são o aumento da relação fibra \%/sacarose nas touceiras doentes, reduzindo a extração de açúcar, e a necessidade de reforma precoce dos canaviais severamente atacados pelo carvão.

É pertinente observar os prejuízos indiretos causados pela doença, ao impedir o cultivo de variedades suscetíveis com boa capacidade produtiva, além do dispêndio de recursos para a manutenção de programas de melhoramento.

Nos programas de melhoramento da cana-de-açúcar, a determinação do nível de resistência em clones e variedades é fundamental. Os testes com inoculação artificial do patógeno são rotineiramente desenvolvidos em diferentes fases destes programas, exigindo grande demanda de pessoal e recursos. A repetição dos testes nas diferentes fases deve-se à alta variabilidade dos resultados obtidos nos ensaios instalados no campo. As razões desta alta variabilidade incluem desuniformidade na infecção das gemas e método de avaliação inadequado. $O$ desenvolvimento de um sistema de avaliação menos oneroso e mais fiel à realidade seria altamente interessante tanto no nível científico como financeiro.

Em função do exposto, os objetivos do presente estudo foram :

(a) Comparar a evolução da doença em termos de perfilhos e touceiras doentes, estabelecendo qual a melhor variável para determinar o nível de resistência das variedades;

(b) Avaliar a redução de produção que o carvão pode causar em variedades de cana-de-açúcar, devido à redução no peso das touceiras. 


\section{REVISÃO DE LITERATURA}

\subsection{Histórico}

O carvão foi uma das primeiras doenças identificadas na cultura da canade-açúcar, devido à formação do chicote, um sinal típico e facilmente observável. O primeiro relato da doença foi feito em Natal, África do Sul, em 1877 quando o cultivo da cana-de-açúcar era incipiente. Neste período, amostras do fungo foram enviadas para a Inglaterra onde foi identificado como Ustilago sacchari Rabehn, um fungo que havia sido anteriormente observado na Índia sobre Saccharum spontaneum L. Contudo, em 1924, Sydow concluiu que o fungo em questão era diferente de Ustilago sacchari e o chamou de Ustilago scitaminea Sydow. A partir da primeira constatação, rapidamente surgiram outros relatos em diferentes localidades onde a cana-de-açúcar era cultivada. Em várias dessas regiões o carvão tornou-se a principal doença da cultura e só foi controlado quando, após o surto inicial, os cultivares suscetiveis foram substituidos por outros com maior resistência (Antoine, 1961). Entre os anos de 1882 e 1930 diversos relatos da doença foram feitos em países da África e Ásia: Java, 1881; Mauritius, 1882; Filipinas, 1908; Moçambique, 1910; Birmânia, 1924; Indochina, 1930. Em 1930 a doença foi observada em Portugal e a partir de 1940 na América do Sul. Em 1940 o fungo atingiu a província de Tucuman, na Argentina de onde se dispersou para outros paises latino-americanos: Paraguai, 1944; Brasil, 1946; Bolívia, 1957; República Dominicana, 1958; Guiana e Cuba, 1978. Em 1971 a doença foi identificada no Havai e entre 1978 e 1981 já era observada em diversos estados continentais dos E.U.A.: Flórida, 1978; Texas e Louisiania, 1981 (Tóffano, 1953; Antoine, 1961; Glaz et al., 1985; Irey, 1986; Hoy et al., 1987; Ferreira \& Comstock, 1989). 
No Brasil, o fungo foi inicialmente observado em 1946 no município de Assis, Estado de São Paulo, incidindo sobre as variedades POJ36 e POJ213. Em 1951 a doença foi identificada em Piracicaba e alguns anos mais tarde encontrava-se disseminada nas regiões Sul e Sudeste. Os maiores niveis de infestação ocorreram na década de 80 , na variedade NA56-79. Somente a partir de 1986 a doença começou a ser observada na Região Nordeste, mais precisamente no Estado do Ceará (Santos et al., 1986). Atualmente, a doença encontra-se disseminada por todo território nacional (Bergamin Filho et al., 1987).

Das grandes regiões produtoras de cana-de-açúcar do mundo, apenas as plantações da Austrália e Fiji permanecem livres do carvão (Ferreira \& Comstock, 1989), contudo a presença do fungo na vizinha Indonésia permite conjecturar que em um futuro próximo o patógeno alcançará estas últimas fronteiras.

\subsection{Importância econômica}

Antoine (1961) relatou que nas Filipinas as perdas no campo devidas à doença chegaram a $50 \%$. Segundo Whittle (1980), no terceiro ano após o surgimento da doença, observou-se perdas ao redor de $10 \%$ no rendimento das variedades afetadas. Os resultados indicaram que $1 \%$ de infecção reduz 0 rendimento em 0,9 \%. Tokeshi (1987) avaliou as perdas causadas pelo carvão em cinco canaviais comerciais da variedade NA56-79, entre os estágios terceiro e quinto cortes e verificou que o nivel médio de incidência de carvão foi de 30878 chicotes/ha. Segundo o autor, as análises estatísticas não demonstraram redução de produção exclusivamente devidas ao carvão quando medidas pela tonelagem de cana, número de colmos, pol \% cana, fibra \% cana, pureza do caldo e açúcar por tonelada de cana. Ferreira \& Comstock (1989) ponderaram que o rendimento do canavial pode ser reduzido em decorrência da redução do diâmetro dos colmos, do teor de sacarose, da relação açúcar/fibra e da redução da pureza do caldo. A diminuição de rendimento nos campos é da ordem de 15 a $22 \%$, além de perdas adicionais de 5 a $10 \%$ durante a fabricação de açúcar. Casagrande \& Sanguino (1994) demonstraram que a incidência do carvão (touceiras doentes) está altamente correlacionada com a redução de peso dos 
colmos, confirmando resultados obtidos por diversos autores em vários países. Comentaram que embora a reação ao carvão seja uma característica varietal, de maneira geral ocorre redução da ordem de $0,69 \%$ para cada $1 \%$ de touceiras afetadas, tanto em cana-planta como na primeira soca.

Geralmente, os prejuizos econômicos decorrentes da doença têm-se mostrado variáveis, principalmente em função da variedade em cultivo. No Brasil, ocorreram dois surtos epidêmicos da doença, acarretando prejuízos aos produtores. O primeiro deles aconteceu na década de 40 , atingindo as variedades POJ36 e POJ213 que devido a alta suscetibilidade precisaram ser erradicadas e substituídas por outras mais resistentes. Com o aumento da resistência dos cultivares, o carvão passou a ter ocorrência endêmica, ficando várias décadas relegado a segundo plano. Contudo, a partir de 1975, devido ao estímulo do Programa Próalcool, a cultura da cana-de-açúcar sofreu rápida expansão e, no início da década de 80, uma variedade, a argentina NA56-79, chegou a ocupar cerca de 50 \% da área cultivada no Estado de São Paulo (Cadernos Copersucar, 1985). A riqueza em açúcar e a precocidade desta variedade fizeram com que ela fosse rapidamente multiplicada sem os devidos cuidados fitossanitários. Tal fato, aliado à baixa resistência à doença, fizeram com que o carvão se espalhasse por extensas áreas de cultivo desta variedade, não sendo raros os casos de incidência superior a $80 \%$ das plantas. Nesta situação, a doençáa obrigou a reforma precoce de canaviais, causando grandes prejuizos aos produtores.

Além dos prejuizos diretos, a doença acarreta outros indiretos: (a) impossibilita o cultivo de variedades altamente produtivas, em vista de sua suscetibilidade ao carvão, (b) obriga a redução de áreas cultivadas com variedades de resistência intermediária, (c) impõe restrições aos programas de melhoramento que são obrigados a descartar clones ricos e produtivos devido à suscetibilidade à doença, (d) provoca elevação de despesas decorrentes de práticas fitossanitárias como tratamento térmico e "roguing" (Comissão de Controle do Carvão da Cana-de-açúcar do Estado de São Paulo, 1985). 


\subsection{Características gerais da doença}

\subsubsection{O patógeno}

O carvão da cana-de-açúcar é causado pelo fungo Ustilago scitaminea Sydow que, como outras espécies de Ustilago, é uma parasito biotrófico que infecta tecidos meristemáticos jovens, penetrando na planta hospedeira exclusivamente através da parte inferior das gemas, abaixo das escamas (EI cañero, 1981). U. scitaminea pertence ao phylum Basidiomycota, ordem Ustilaginales, familia Ustilaginaceae, sendo seu ciclo de vida típico dos fungos deste grupo (Alexopoulos et al., 1996).

Os teliósporos, esporos assexuados do patógeno, são formados em agregados, geralmente localizados no meristema apical das plantas. Essa formação é popularmente conhecida como "chicote" e pode conter de 3 a 5 bilhões de teliósporos (Sanguino, 1987). Os teliósporos são propágulos esféricos, unicelulares e dicarióticos (Bedendo, 1995) que germinam sob condições de elevada umidade, originando, após cariogamia e meiose, um promicélio com dimensões aproximadas de $16 \mu \mathrm{m}$ de comprimento por 3 a $4 \mu \mathrm{m}$ de largura, geralmente septado transversalmente em 3 a 4 células (Antoine, 1961). Normalmente, o promicélio diferencia-se numa basídia septada, a qual origina basidiósporos, também chamados esporídios que são esporos sexuados, cilíndricos, unicelulares e haplóides. Germinando, os basidiósporos dão origem a hifas primárias que, através de plasmogamia, juntam-se duas a duas formando as hifas secundárias, dicarióticas que penetram e colonizam os tecidos da planta. Segundo Bock (1964), a infecção do hospedeiro também pode ocorrer por meio de hifas produzidas diretamente pelo promicélio, são as chamadas hifas infectivas. A formação dos teliósporos se dá através da clivagem das hifas secundárias (Bedendo, 1995).

A ocorrência de raças fisiológicas é um tema bastante controvertido. Embora alguns pesquisadores como Leu \& Tseng (1974) em Formosa e Comstock \& Heinz (1977) no Havaí tenham determinado sua ocorrência, a metodologia empregada nos experimentos deixa dúvidas quanto aos resultados obtidos. Tokeshi (1985), comentando tais trabalhos, argumenta que os mesmos 
não respeitaram a resistência morfológica conferida pelas escamas das gemas, ficando, portanto, sujeitos a críticas.

\subsubsection{Sintomas}

O carvão da cana-de-açúcar é uma doença de fácil diagnóstico, devido à produção do apêndice denominado chicote que é sua característica inconfundivel. A denominação carvão deve-se à presença de massas pulverulentas de coloração negra encontradas na parte aérea de plantas doentes (Bedendo, 1995). Os chicotes são formados após severas modificações morfológicas do hospedeiro, podendo surgir tanto no meristema apical como nas gemas laterais. No primeiro caso, a infecção ocorre devido ao inóculo presente no solo que penetra no hospedeiro por ocasião da brotação das gemas, caracterizando a infecção primária. Por outro lado, a infecção secundária ocorre quando propágulos carregados pelo vento ou água da chuva são depositados e germinam sobre as gemas laterais do hospedeiro. A posição do chicote também diferencia o tipo de dispersão dos teliósporos. Os chicotes apicais, por se posicionarem acima do nivel das plantas, favorecem o carregamento dos teliósporos pelo vento, permitindo que os mesmos se depositem a distâncias relativamente longas em relação à fonte, possibilitando a infecção de novas plantas. No caso dos chicotes laterais, situados no interior da cultura, as próprias plantas funcionam como barreira contra a dispersão dos propágulos, fazendo com que estes sejam depositados no mesmo hospedeiro onde foram originados ou, no máximo, naqueles imediatamente vizinhos à fonte. Por estas características de dispersão dos teliósporos pode-se dizer, de acordo com os conceitos de Robinson (1976), que os chicotes apicais são de grande importância na aloinfecção enquanto os chicotes laterais contribuem principalmente para a autoinfecção (Amorim, 1990). Segundo Tokeshi (1985), os chicotes normalmente surgem 2 a 3 meses após o plantio e chegam a crescer cerca de $2 \mathrm{~cm}$ por dia. Inicialmente mais intenso, o periodo de crescimento deste apêndice geralmente se encerra após três meses, quando a estrutura pode variar de alguns centímetros até mais de um metro de comprimento. O chicote é formado por uma estrutura central, sobre a qual o fungo forma seus esporos, de cor negra, em grande quantidade (Comissão de Controle do Carvão da Cana-de-açúcar do 
Estado de São Paulo, 1985). De acordo com Waller (1969), a liberação diária de esporos produzidos por um único chicote na variedade $\mathrm{H} 44-3098$ variou de 100 milhões a 1 bilhão, estes chicotes tinham em média $90 \mathrm{~cm}$ de comprimento e durante os 3 meses de crescimento, cada um foi responsável pela liberação de aproximadamente 100 bilhões de esporos. Antes do aparecimento dos chicotes, as plantas infectadas podem apresentar sintomas menos evidentes como afinamento dos colmos, folhas mais curtas e com ângulo de inserção mais agudo no caule e tendência ao superbrotamento, dando origem a touceiras com aspecto de capim (Bergamin Filho et al., 1987). Em variedades suscetiveis, o carvão pode ocasionar a morte das plantas infectadas.

\subsubsection{Ciclo da doença}

Conhecer com detalhes o ciclo de uma doença é fundamental para a formulação de estratégias de controle. O carvão da cana-de-açúcar apresenta dois ciclos distintos designados primário e secundário. O ciclo primário inicia com a infecção primária que pode ocorrer através do plantio em solos contaminados, pela utilização de mudas infectadas ou em decorrência do transporte aéreo dos teliósporos oriundos de plantações vizinhas, caracterizando-se pela introdução do patógeno em área indene. Contrariamente, o ciclo secundário caracteriza-se pela propagação do patógeno em uma área onde o mesmo já havia sido introduzido, podendo originar chicotes apicais em perfilhos emergentes ou laterais caso sejam infectadas gemas de colmos desenvolvidos. Medidas como a utilização de mudas sadias e eliminação de focos da doença são eficientes no combate ao ciclo primário, enquanto que a eliminação dos chicotes e plantas que os produzem ("roguing") atua sobre o ciclo secundário (Bergamin Filho et al., 1987).

\subsection{Controle}

No inicio do século, em 1925, Whetzel et al. definiram controle como a prevenção dos prejuízos causados por uma doença, dando uma conotação econômica ao conceito. Com o desenvolvimento da fitopatologia, o controle passou a ter uma concepção biológica, sendo em 1968 definido como a redução 
na incidência ou severidade de uma doença (Kimati \& Bergamin Filho, 1995). Na agricultura comercial, o objetivo final dos fitopatologistas é promover o controle das doenças, baseado na redução da incidência ou severidade e objetivando a prevenção dos prejuizos.

Na cultura da cana-de-açúcar, a medida de controle mais eficaz contra o carvão é a resistência varietal (Antoine, 1961), sendo as demais medidas empregadas quando a variedade não apresenta um nivel de resistência satisfatório. As outras medidas de controle são: utilização de mudas sadias e "roguing" (Comstock et al., 1983; Bergamin Filho et al., 1987).

\subsubsection{Obtenção de variedades resistentes}

O primeiro programa de melhoramento genético da cana-de-açúcar foi desenvolvido em Java, no final do século passado, em decorrência da necessidade de se obter variedades resistentes às doenças (Sordi et al., 1988b). Contudo, como enfatiza Tokeshi (1985), a probabilidade de se obter uma variedade ideal, rica em açúcar, produtiva e resistente às doenças e pragas, é bastante pequena. Atualmente, a obtenção de variedades resistentes ao carvão é uma preocupação comum a todos os programas de melhoramento da cana-deaçúcar, que adotam diferentes estratégias para produzi-las (Comstock et al., 1983). A seleção de genitores com comprovada resistência e a eliminação dos clones suscetiveis são técnicas de eficiência comprovada, empregadas em diversos programas de melhoramento (Comstock et al., 1983; Benda, 1987; Machado Junior et al., 1987; Lo, 1987).

Os trabalhos de Wu et al. (1977), Ladd et al. (1977) e Sordi et al. (1988a) demonstraram que a herdabilidade à resistência ao carvão é alta, ao correlacionar a reação dos clones com a de seus genitores. Nos programas de melhoramento desenvolvidos nos E.U.A. para a obtenção de variedades $H$ e CP, após a eliminação dos genitores suscetiveis presentes na coleção de germoplasma, observou-se uma drástica diminuição nos niveis de doença nos clones em seleção. Em apenas cinco anos, a orientação dos cruzamentos fez com que o número de plântulas suscetiveis diminuisse de $64 \%$ para apenas $11 \%$ (Miller, 1979). Todavia, como esclarece Peixoto (1981), em paises como o 
Brasil, onde a cana-de-açúcar é cultivada em grandes extensões sujeitas a alta diversidade edafoclimática, os programas de melhoramento precisam manter uma ampla base genética e a resistência ao carvão deve ser apenas um critério adicional de seleção.

A determinação do nivel de resistência dos clones dentro dos programas de melhoramento é feita através de testes onde os clones, juntamente com algumas variedades de reação conhecida, são expostos ao patógeno (inoculação artificial) e posteriormente monitorados a fim de determinar o nivel de doença em cada individuo. O processo de inoculação artificial pode ser realizado de diferentes formas, cada qual apresentando prós e contras. Os principais métodos utilizados são a imersão de toletes em uma suspensão de teliósporos (Hirschhorn, 1950), aplicação de pasta contendo teliósporos sobre as gemas dos toletes (Srinivasan, 1969), ferimento de gemas com agulha previamente imersa em suspensão de teliósporos (Leu et al., 1970) e pulverização das gemas com uma suspensão de teliósporos (Copersucar, 1995). Este último método vem sendo regularmente utilizado pela Copersucar em seus testes para caracterizar a reação de genitores e clones uma vez que experimentos preliminares demonstraram sua eficiência e aplicabilidade. A grande vantagem deste método é permitir a inoculação de um número elevado de indivíduos com uma pequena quantidade de inóculo. Segundo Tokeshi (1985), todos os métodos de inoculação acarretam um determinado grau de "sacrifício" no mecanismo de resistência e o ideal seria analisar os indivíduos sob condições naturais de infecção no campo, sem a interferência do homem. Contudo, este modelo requer áreas de cultivo bastante extensas, vários anos de avaliação e custo elevado que o tornam impraticável.

A concentração de teliósporos nas suspensões usadas na inoculação artificial é fundamental para o sucesso dos testes para avaliação da resistência de clones e genitores. Resultados de diversos autores demonstraram que variedades suscetíveis necessitam pelo menos 10 a 50 mil esporos $/ \mathrm{ml}$ para obter de 12 a $20 \%$ das plantas infectadas. Variedades com resistência intermediária precisam de 1 a 10 milhões de esporos $/ \mathrm{ml}$ para apresentarem $20 \%$ das plantas infectadas. As variedades altamente resistentes apresentam 
reações constantes até a concentração máxima de 100 milhões de esporos / ml (Tokeshi, 1985).

\subsubsection{Obtenção de mudas sadias}

A produção de mudas sadias requer tecnologia, nem sempre disponivel aos produtores. Mudas sadias são obtidas de toletes sadios, sem infecção latente. O tratamento térmico a $50,5^{\circ} \mathrm{C}$ por duas horas garante a sanidade dos toletes para o plantio, eliminando possiveis infecções preexistentes (Amorim, 1990). Após o tratamento, os toletes devem ser plantados na área selecionada para o viveiro que deve obrigatoriamente estar localizada em local isolado, afastado de áreas de cultivo comercial. Segundo Tokeshi (1985), os estudos de dispersão dos esporos de carvão demonstraram que acima de $40 \mathrm{~m}$ de distância dos focos a concentração de esporos tende a ser muito baixa e provavelmente é insuficiente para causar infecção. $O$ autor sugere que sejam plantadas bordaduras ao redor do viveiro empregando uma variedade altamente resistente ao fungo, formando uma barreira que impede o acesso dos propágulos às plantas do viveiro.

Mesmo empregando as medidas anteriormente citadas, são necessárias inspeções periódicas na área do viveiro para eliminação das plantas doentes ("roguing"), caso ocorram. De acordo com Tokeshi (1985), é fundamental que a planta doente seja eliminada imediatamente após o surgimento do chicote pois, segundo Waller (1969), na primeira semana após o surgimento do chicote ocorre a liberação de maiores quantidades de esporos, cerca de 1 a 10 bilhões de esporos / dia, que podem atingir plantas vizinhas num raio de até $40 \mathrm{~m}$ da fonte. O mesmo autor enfatiza a importância da freqüência das operações de "roguing", lembrando que quando realizadas mensalmente possibilitam que neste periodo, um único chicote propicie a liberação de até 30 milhões de esporos.

\subsection{3. "Roguing"}

A prática do "roguing" visa à eliminação de plantas doentes presentes em determinada área de cultivo, incluindo as plantas com carvão. Para esta doença 
existem dois tipos de "roguing": o total e o parcial. No primeiro caso, toda a touceira é eliminada, por pulverização com um herbicida, ou simplesmente arrancada com auxílio de um enxadão. Já no "roguing" parcial apenas o perfilho doente é extirpado, permanecendo o restante da touceira intacta. Contudo, em ambos os casos, antes da eliminação da touceira ou perfilho, deve ocorrer a extirpação cuidadosa do chicote, evitando que os esporos sejam disseminados. Para tanto, o responsável deve levar consigo um saco plástico, onde os chicotes são colocados após serem cortados. No final da jornada de trabalho, o saco contendo os chicotes deve ser incinerado. O "roguing" químico com herbicida facilita e acelera o trabalho e pode ser realizado com uma solução de glifosato a $6 \%$ em volume, aplicada com auxilio de um pulverizador costal, com $5 \mathrm{I}$ de capacidade, nos cartuchos das folhas da touceira doente. Sordi et al. (1988b) recomendam que se faça "roguing" mensal apenas nos viveiros pois a sua realização em áreas comerciais de grande extensão seria antieconômica. Por outro lado, Tokeshi (1985) diz que a prática de "roguing" eliminando colmos ou touceiras em áreas industriais, é pratica adotada em diversos países produtores de cana-de-açúcar, visando à diminuição do potencial de inóculo. Além disso, enfatiza que o sucesso desta operação depende da freqüência com que é realizada. Trabalhando com as variedades NCo310 e NCo376, James (1974) concluiu que os efeitos do "roguing" variam de acordo com a variedade. No caso da NCo310, a prática do "roguing" não trouxe benefícios à produção de colmos e de açúcar por hectare, não havendo diferenciação no número de chicotes observados nas áreas submetidas ou não ao "roguing". Por outro lado, o "roguing" foi benéfico para a produção da NCo376 em relação aos dois índices analisados. Atualmente, devido à obrigatoriedade da diminuição de custos na agroindústria açucareira, os produtores estão diminuindo ou eliminando as equipes responsáveis pelo "roguing", sem se preocupar com os efeitos adversos desta medida.

\subsubsection{Controle químico}

Como para a maioria das doenças da cana-de-açúcar, o controle químico do carvão em áreas extensas é uma prática antieconômica. Segundo Amorim (1990), embora os fungicidas sistêmicos do grupo dos inibidores da síntese do 
ergosterol sejam bastante eficientes no controle da doença, sua utilização em larga escala é proibitiva devido ao elevado custo do tratamento. Pesquisas realizadas no extinto Planalsucar, avaliando a possibilidade do uso de fungicidas no controle do carvão, demonstraram que os sistêmicos triadimenol e fluzilazole podem conferir uma boa proteção na cana-planta, contudo seus efeitos residuais não foram suficientes para promover um controle efetivo também nas socas (Sordi et al., 1988b).

\subsection{Critérios para a quantificação da doença}

Embora o carvão seja uma das doenças de mais fácil diagnose em canade-açúcar, a quantificação da sua intensidade apresenta grandes variações, decorrentes das variáveis levantadas no campo e também dos critérios estabelecidos para analisá-las.

Segundo Amorim (1995), a quantificação de doenças é necessária tanto para o estudo de medidas de controle, na determinação da eficiência de um fungicida ou na caracterização da resistência varietal, como para a epidemiologia na construção de curvas de progresso da doença e estimativa dos danos provocados por ela.

No caso especifico do carvão, a falta de padronização nos experimentos para avaliar o nivel de resistência dos cultivares começa com o tipo de inoculação e termina com a metodologia empregada na quantificação da doença, dificultando a comparação dos resultados obtidos em diferentes instituições. Nos programas de melhoramento, os critérios de avaliação e classificação em relação ao carvão são de elevada importância pois os clones suscetiveis devem ser caracterizados e descartados durante as diferentes fases de seleção.

Basicamente são quatro as variáveis que podem ser utilizadas para avaliar a incidência do carvão sobre um determinado cultivar. Estas variáveis podem ser cumulativas ou não cumulativas e representar um ou mais ciclos da doença. As variáveis usadas são: perfilhos doentes por unidade de área (PDP), perfilhos doentes por touceira (PDT), touceiras doentes por unidade de área (TDP) e touceiras mortas por unidade de área (TMP). A necessidade de mão de 
obra varia muito em cada caso. Levantamentos de perfilhos doentes (PDP ou PDT) são muito mais demorados e sujeitos a erros quando comparados à avaliação de touceiras doentes. Em contrapartida, os testes cuja incidência da doença é baseada em touceiras doentes exigem pré-plantio em casa de vegetação de toletes de uma gema e posterior transplante no campo, pois esta é a única maneira segura de individualizar as touceiras. Se por um lado isto torna o processo inicial mais trabalhoso, a mão de obra total é grandemente reduzida com o decorrer dos levantamentos ao longo dos ciclos da cultura. Outra vantagem do pré-plantio em casa de vegetação é a possibilidade de um maior controle da temperatura e umidade no ambiente durante a inoculação, auxiliando o processo de infecção e diminuindo o número de "escapes".

Quando estas variáveis são apresentadas em valores percentuais, a exigência de mão-de-obra é ainda maior. A obtenção da porcentagem de perfilhos doentes exige a contagem de todos os perfilhos da parcela, enquanto que para a porcentagem de touceiras doentes basta conhecer o número de plantas da parcela. Dados cumulativos exigem que chicotes e perfilhos determinados no levantamento anterior sejam marcados a fim de não serem novamente contados no próximo. Quando se trabalha com perfilhos doentes, estas estruturas devem ser marcadas a cada levantamento e isto normalmente é feito amarrando-se uma fita plástica em todos os colmos que apresentarem chicote. Trabalhando com touceiras doentes basta amarrar uma fita em um dos perfilhos quando estas exibirem a doença.

Tanto perfilhos doentes (James, 1969; Silva \& Sanguino, 1978; Figueiredo et. al., 1980), como touceiras doentes (Alexander, 1982; Waraitch, 1982; Handojo \& Legowo, 1984; Glaz et al., 1985; El-Kholi, 1996) podem ser utilizados como variáveis de incidência da doença. Na Tailândia, lamsupasit et al. (1996) caracterizaram a reação de clones em relação ao carvão utilizando um critério que considera a porcentagem de touceiras infectadas e o número de chicotes. Contudo os autores não explicam como estas informações são usadas para determinar o nível de resistência dos clones.

Whittle \& Walker (1982) concluíram que a quantificação do nível de resistência de determinado cultivar deve ser feita com base no número de perfilhos doentes. Os autores apontam razões estatísticas e lógicas para a 
adoção desta medida para avaliação da doença. Parcelas pequenas, com apenas 10 touceiras não podem ser avaliadas em função do número de plantas doentes pois a população não é significativa. Contudo, nestas mesmas parcelas normalmente ocorrem mais de 100 perfilhos que formam uma população passível de análise. Quando muitos perfilhos doentes se concentram em poucas touceiras, a quantificação da doença baseada na proporção de plantas infectadas é subestimada. Em outros casos, a doença pode atingir $100 \%$ das plantas e a quantificação baseada nesta variável é usualmente muito maior que a baseada no número de perfilhos doentes. A proporção de touceiras doentes indica a freqüência de infecção mas não fornece indicação da produção de chicotes ou da probabilidade de perdas na produção. Neste trabalho, contudo, os autores usam uma terminologia que deixa a desejar quando fazem referência à freqüência e intensidade de doença que, segundo James (1974) apresentam outro significado. Melhor seria chamar o número de touceiras doentes de incidência e, lembrar que o termo intensidade, utilizado com o significado de número de chicotes por unidade de área, é um termo muito genérico.

Segundo James (1969), a comparação entre a incidência da doença na cana-planta e na primeira soca mostrou que a porcentagem de touceiras doentes não apresentou diferenças significativas, porém o número de chicotes produzidos por touceiras infectadas apresentou significativo decréscimo na primeira soca.

Foi Momol (1986) quem desenvolveu o mais amplo estudo para determinar o melhor critério para determinar a incidência do carvão em cultivares de cana-de-açúcar. Foram usadas três variáveis para calcular a incidência da doença: porcentagem de plantas infectadas (IP), porcentagem de perfilhos infectados (IS) e porcentagem de perfilhos infectados por planta (ISP). Estas variáveis foram comparadas em função da área abaixo da curva de progresso da doença (AUDPC), sendo a curva de IS similar à de ISP, porém, ambas foram diferentes da curva de IP. Nos estágios iniciais da doença, quando IS e ISP são baixos, estas duas variáveis apresentam grande similaridade com IP, porém, esta similaridade desaparece com o desenrolar da epidemia. Em condições de alta pressão de inóculo, IP atingiu $100 \%$ no mesmo período em que IS e ISP atingiram 50 \%. As avaliações baseadas em IP permitem a observação de mais de um ciclo do patógeno durante um ciclo de crescimento das plantas. Os clones 
podem apresentar um ou dois ciclos do patógeno sendo os primeiros preferidos dentro dos programas de seleção. Embora apresentem resultados similares, IS deve ser preferido a ISP devido a sua maior facilidade de obtenção.

\subsection{Correlação entre a incidência da doença e os níveis de dano}

Conforme a conceituação proposta por Chiarappa (1971) e modificada por Zadoks (1985), qualquer redução na qualidade e/ou quantidade da produção é chamada dano.

Segundo James (1983), a falta de dados quantitativos confiáveis a respeito da importância das doenças foi, isoladamente, o fator que mais prejudicou o avanço da fitopatologia como ciência. Analisando esta afirmação, Bergamin Filho (1995), admitiu tratar-se de uma situação paradoxal, uma vez que - estudo das doenças em plantas teve início em função das perdas que causavam. Para investir em controle, seja ele de qualquer espécie, é necessário obter previamente uma estimativa confiável das reduções de produção acarretadas pelo patógeno.

Alexander (1982) não conseguiu relacionar redução de produção com incidência da doença quando esta foi medida como porcentagem de touceiras infectadas.

Segundo Hoy (1986), a produção de cana-de-açúcar medida em toneladas por hectare $(\mathrm{TCH})$ apresentou correlação negativa com niveis crescentes da incidência de carvão calculada pela porcentagem de perfilhos doentes para a variedade CP73-351. O efeito mais significativo do carvão na produção foi a redução no número de perfilhos sadios nas plantas infectadas. $A$ correlação entre a porcentagem de perfilhos doentes e a produção (TCH) estimada em três campos diferentes apresentou coeficiente de determinação $\left(R^{2}\right)$ variando entre 0,60 e 0,74 na cana-planta e para um dos campos foi igual a 0,79 na primeira soca. 
Em experimento delineado especificamente para avaliar os danos do carvão, dados de produção foram coletados a partir de 24 parcelas da variedade CL65-260, apresentando diferentes níveis de infecção pelo patógeno (Irey, 1986). A incidência do carvão foi avaliada por porcentagens de perfilhos e touceiras doentes. Quando os dados de produção foram relacionados aos de incidência de doença, a porcentagem de perfilhos doentes apresentou um maior coeficiente de determinação que a porcentagem de touceiras doentes, indicando que as perdas estão mais relacionadas ao número de perfilhos doentes. Na cana-planta, para cada $1 \%$ de perfilhos doentes ocorreu uma perda de 0,46 tha e 0,66 tha para cada $1 \%$ de touceiras infectadas. É pertinente observar que neste trabalho, o autor avaliou o número inicial de touceiras através do número de brotos primários observados aproximadamente dois meses após o plantio das parcelas com toletes de 3 a 4 gemas. Além disso, em levantamentos para determinar a incidência da doença o critério usado para individualização das touceiras foi "visual". É difícil entender como é possível delimitar visualmente uma touceira quando os toletes plantados apresentavam mais de uma gema. Portanto, neste trabalho, as informações baseadas em porcentagem de touceiras doentes devem ser vistas com cautela.

Casagrande \& Sanguino (1994), trabalhando com touceiras individualizadas, determinaram que embora a reação ao carvão seja uma característica varietal, a incidência da doença baseada em touceiras infectadas está altamente correlacionada com a perda de peso dos colmos. Tanto na canaplanta como na primeira soca para cada $1 \%$ de touceiras infectadas ocorreu $0,69 \%$ de diminuição no peso final dos colmos com coeficientes de correlação $(R)$ iguais a 0,95 e 0,94 , respectivamente. 


\section{MATERIAL E MÉTODOS}

\subsection{Local e variedades}

O experimento foi conduzido no Centro de Tecnologia Copersucar (CTC) em Piracicaba, SP, no período de outubro de 1992 a julho de 1996 . Foram utilizadas 18 variedades de cana-de-açúcar (híbridos interespecíficos de Saccharum), com reação conhecida ao carvão (Tabela 1).

Tabela 1 - Genitores, países de origem e reação ao carvão das variedades de cana-de-açúcar utilizadas no experimento.

\begin{tabular}{|c|c|c|c|c|c|}
\hline \multirow[b]{2}{*}{ Variedade } & \multicolumn{2}{|c|}{ Genitor } & \multirow[b]{2}{*}{ Origem } & \multirow[b]{2}{*}{ Reação ao carvão } & \multirow{2}{*}{$\begin{array}{l}\text { Local de determinação } \\
\text { da reação ao carvão }\end{array}$} \\
\hline & Feminino & Masculino & & & \\
\hline $\begin{array}{l}\text { B52107 } \\
\text { CB40-35 } \\
\text { Co421 }\end{array}$ & $\begin{array}{l}\text { B4145 } \\
\text { POJ2878 } \\
\text { POJ2878 }\end{array}$ & $\begin{array}{l}\text { B41227 } \\
\text { Co290 } \\
\text { Co285 }\end{array}$ & $\begin{array}{l}\text { Barbados } \\
\text { Brasil } \\
\text { India }\end{array}$ & $\begin{array}{l}\text { resistente } \\
\text { intermediária } \\
\text { intermediária }\end{array}$ & $\begin{array}{l}\text { E.U.A. } \\
\text { Brasil } \\
\text { Africa do Sul }\end{array}$ \\
\hline $\begin{array}{l}\text { Co462 } \\
\text { Co6806 }\end{array}$ & $\begin{array}{l}\text { Co421 } \\
\text { Co775 }\end{array}$ & $\begin{array}{l}\text { Co313 } \\
\text { Co798 }\end{array}$ & $\begin{array}{l}\text { India } \\
\text { India }\end{array}$ & $\begin{array}{l}\text { intermediária } \\
\text { resistente }\end{array}$ & $\begin{array}{l}\text { Brasil } \\
\text { Brasil }\end{array}$ \\
\hline $\begin{array}{l}\text { CP23-588 } \\
\text { CP29-116 } \\
\text { F134 }\end{array}$ & $\begin{array}{l}\text { CL54-191 } \\
\text { POJ2725 } \\
\text { Co290 }\end{array}$ & $\begin{array}{l}\text { CP57-120 } \\
\text { CP1165 } \\
\text { POJ2878 }\end{array}$ & $\begin{array}{l}\text { E.U.A. } \\
\text { E.U.A. } \\
\text { Formosa }\end{array}$ & $\begin{array}{l}\text { resistente } \\
\text { resistente } \\
\text { intermediária }\end{array}$ & $\begin{array}{l}\text { Brasil } \\
\text { E.U.A. } \\
\text { Barbados }\end{array}$ \\
\hline $\begin{array}{l}\text { H50-7209 } \\
\text { IAC66/6 }\end{array}$ & $\begin{array}{l}\mathrm{H} 44-3098 \\
\mathrm{Co} 419\end{array}$ & $\begin{array}{l}? \\
\text { Co356 }\end{array}$ & $\begin{array}{l}\text { E.U.A. } \\
\text { Brasil }\end{array}$ & $\begin{array}{l}\text { suscetivel } \\
\text { suscetivel }\end{array}$ & $\begin{array}{l}\text { E.U.A. } \\
\text { Brasil }\end{array}$ \\
\hline M31/45 & M134/32 & M99/34 & Mauritius & resistente & Barbados \\
\hline NA56-79 & Co419 & "SELF" & Argentina & suscetivel & Brasil \\
\hline NCo310 & Co421 & Co312 & África do Sul & suscetivel & África do Sul \\
\hline SP70-1143 & IAC48/65 & $?$ & Brasil & resistente & Brasil \\
\hline SP71-1406 & NA56-79 & $?$ & Brasil & intermediária & Brasil \\
\hline SP71-6163 & NA56-79 & $?$ & Brasil & resistente & Brasil \\
\hline SP71-8210 & AKBAR & CB49-260 & Brasil & resistente & Brasil \\
\hline SP79-1011 & NA56-79 & Co775 & Brasil & resistente & Brasil \\
\hline
\end{tabular}

Fonte : arquivos do Centro de Tecnologia Copersucar (CTC). 


\subsection{Preparo do material vegetal}

As variedades utilizadas no experimento foram obtidas de um único viveiro e contavam com 11 meses de idade. Este viveiro foi inspecionado rotineiramente a partir do segundo mês após o plantio com a finalidade de eliminar as plantas que apresentassem sintomas de carvão, mosaico ou escaldadura.

Para cada variedade foram selecionados aproximadamente 300 toletes com uma gema que, logo após o corte, foram selecionados, etiquetados e submetidos à inoculação artificial de carvão.

\subsection{Preparo do inóculo e inoculação}

A inoculação foi realizada por meio de imersão dos toletes durante $30 \mathrm{~min}$ em uma suspensão aquosa de teliósporos de Ustilago scitaminea, conforme técnica proposta por Hirschhorn (1950) Para obtenção da suspensão, $300 \mathrm{~g}$ de teliósporos foram diluídos em 200 / de água, juntamente com a adição de $2 \mathrm{ml}$ de Tween-80. Os teliósporos foram coletados e armazenados conforme recomendações feitas por Mata (1975) e, por ocasião da inoculação, apresentavam viabilidade (medida em ágar-água) igual a $86 \%$. Após a inoculação, os toletes foram plantados em copos plásticos contendo aproximadamente $200 \mathrm{ml}$ de substrato esterilizado. Na seqüência, o material plantado foi regado com $10 \mathrm{ml}$ da suspensão utilizada para a inoculação.

\subsection{Formação de mudas para o plantio}

Após a inoculação e plantio o material foi mantido em casa de vegetação com temperatura controlada ao redor de $30^{\circ} \mathrm{C}$ e irrigação constante. Em 02/12/92 foram agrupadas 144 plantas de mesmo porte de cada variedade. Estes grupos foram aleatoriamente subdivididos em 4 blocos, cada um com 36 plantas 
e levados para o campo, onde o experimento foi instalado em solo tipo podzólico vermelho-amarelo (PVA), ocupando cerca de 0,23 ha.

\subsection{Delineamento experimental}

O delineamento utilizado foi blocos casualizados com quatro repetições (Anexo 1). Cada parcela contava com três sulcos de $7,5 \mathrm{~m}$, espaçados a $1,4 \mathrm{~m}$. Em cada linha transplantou-se 12 plantas espaçadas a $0,5 \mathrm{~m}$, sendo deixado $1 \mathrm{~m}$ de sulco livre em cada extremidade, totalizando 36 plantas isoladas por bloco e 144 nas quatro repetições. O experimento foi isolado por uma bordadura da variedade SP70-1143 com aproximadamente $4 \mathrm{~m}$ de largura. As dimensões do campo experimental foram:

Área útil da parcela .....................31,5 $\mathrm{m}^{2}$

Área útil do bloco ......................567,0 m²

Área útil do experimento ...........2 268,0 $\mathrm{m}^{2}$

\subsection{Avaliações de incidência}

O material transplantado no campo foi constantemente monitorado durante quatro ciclos da cultura. $\mathrm{Na}$ cana-planta foram realizados quatro levantamentos. No primeiro, foram anotados o número total de perfilhos sadios (NTPS) e doentes (NTPD) e nos demais, NTPS e o número de perfilhos doentes surgidos após o levantamento anterior (NNPD). Para a obtenção destas informações, em cada levantamento os perfilhos doentes foram amarrados com fita plástica colorida. Em levantamentos posteriores contava-se NTPS e apenas os perfilhos doentes que não apresentavam fitas, este valor representa os novos chicotes surgidos após o levantamento anterior e permitiram a obtenção do valor acumulado da incidência da doença. Após a contagem, os perfilhos doentes recebiam uma fita plástica colorida. 
Em 13/10/93 foi realizado o primeiro corte do experimento, no qual foram anotados o número de perfilhos industrializáveis (NPI), que são os perfilhos passiveis de aproveitamento na indústria, e o peso total dos mesmos (PPI), para cada uma das touceiras de cada variedade.

A partir da primeira soca, além dos dados cumulativos, contou-se o número total de perfilhos sadios (NVPS) e doentes (NVPD) visiveis em cada levantamento, desconsiderando as fitas. Caso um perfilho estivesse amarrado com fita plástica, mas o chicote não fosse visivel, o mesmo era contabilizado como sadio. Estes dados permitiram a obtenção de variáveis não cumulativas da incidência da doença. No final de cada ciclo as touceiras foram cortadas e pesadas de maneira idêntica ao descrito para a cana-planta.

Durante todos os levantamentos, as informações relevantes de outras doenças como mosaico e ferrugem também foram anotadas. O cronograma com as atividades realizadas no experimento está disposto na Tabela 2. 
Tabela 2 - Cronograma de atividades realizadas no experimento.

\begin{tabular}{lc}
\hline Evento & Data \\
\hline Inoculação e plantio em casa de vegetação & $01 / 10 / 92$ \\
Transplante no campo & $02 / 12 / 92$ \\
$1^{\circ}$ Levantamento & $08 / 02 / 93$ \\
$2^{\circ}$ Levantamento & $23 / 03 / 93$ \\
$3^{\circ}$ Levantamento & $26 / 04 / 93$ \\
$4^{\circ}$ Levantamento & $11 / 08 / 93$ \\
$1^{\circ}$ corte & $14 / 10 / 93$ \\
$5^{\circ}$ Levantamento & $04 / 01 / 94$ \\
$6^{\circ}$ Levantamento & $17 / 02 / 94$ \\
$7^{\circ}$ Levantamento & $29 / 03 / 94$ \\
$8^{\circ}$ Levantamento & $19 / 05 / 94$ \\
$2^{\circ}$ corte & $24 / 05 / 94$ \\
$9^{\circ}$ Levantamento & $27 / 09 / 94$ \\
$10^{\circ}$ Levantamento & $01 / 11 / 94$ \\
$11^{\circ}$ Levantamento & $23 / 12 / 94$ \\
$12^{\circ}$ Levantamento & $21 / 02 / 95$ \\
$13^{\circ}$ Levantamento & $02 / 05 / 95$ \\
$14^{\circ}$ Levantamento & $05 / 06 / 95$ \\
$3^{\circ}$ corte & $06 / 06 / 95$ \\
$15^{\circ}$ Levantamento & $30 / 11 / 95$ \\
$16^{\circ}$ Levantamento & $13 / 03 / 96$ \\
$17^{\circ}$ Levantamento & $10 / 05 / 96$ \\
$18^{\circ}$ Levantamento & $10 / 06 / 96$ \\
$4^{\circ}$ corte & $01 / 07 / 96$ \\
\hline
\end{tabular}

\subsection{Análise de variáveis para quantificar a incidência da doença}

Segundo Amorim (1995), incidência é definida como a porcentagem de plantas doentes ou partes de plantas doentes em uma amostra ou população. De acordo com este conceito, as informações coletadas no campo permitiram a obtenção de diferentes variáveis para determinar a incidência da doença nas variedades, visando caracterizar a reação destas em relação ao patógeno. As variáveis calculadas foram:

a. Porcentagem acumulada de touceiras doentes por parcela (PATDP)

b. Porcentagem não acumulada de touceiras doentes por parcela (PNTDP) 
c. Porcentagem acumulada de perfilhos doentes por parcela (PAPDP)

d. Porcentagem não acumulada de perfilhos doentes por parcela (PNPDP)

e. Porcentagem acumulada de perfilhos doentes por touceira (PAPDT)

f. Porcentagem não acumulada de perfilhos doentes por touceira (PNPDT)

g. Porcentagem acumulada de touceiras mortas por parcela (PATMP)

As variedades com reação conhecida e apresentando diferentes graus de resistência, serviram como base para a comparação das variáveis de incidência da doença, além de permitir avaliar a eficiência da inoculação do patógeno.

As touceiras mortas pelo carvão em determinado levantamento foram contabilizadas como touceiras doentes nos levantamentos posteriores. Esta variável foi a única que pôde ser acumulada ao longo dos ciclos da cultura. Assim, por exemplo, uma touceira morta pela doença na cana-planta foi contabilizada como touceira doente na quarta soca. Embora a touceira morta não continue contribuindo para a evolução da doença, ela sem dúvida é um indicativo de suscetibilidade ao patógeno e, caso fosse desconsiderada, provocaria a subestimação da incidência da doença quando a variável utilizada fosse baseada na porcentagem de touceiras doentes.

Para cada variável foram calculados o valor médio de incidência (VM) e a área abaixo da curva de progresso da doença (AUDPC) em cada ciclo da cultura, descritos nos próximos itens.

A escolha da melhor variável ocorreu em função dos menores valores obtidos para a significância da diferença apontada no teste $F(P)$, em porcentagem, descrita neste trabalho como PTRAT(\%) e para o coeficiente de variação de cada ensaio (CV(\%)). Quanto menor o valor de PTRAT(\%), menor a probabilidade de aceitar que existe pelo menos um contraste significativo entre os valores das variáveis, e este contraste não existir.

Uma vez determinada a melhor variável dentro de cada ciclo, utilizou-se os dados de dois ou mais ciclos consecutivos da cultura numa análise conjunta, para verificar se ocorreria redução nos parâmetros PTRAT(\%) e CV(\%). 


\subsubsection{Valor médio da incidência acumulada de doença (VM)}

Para cada uma das variáveis, em cada ciclo da cultura, o valor médio (VM) foi obtido através da média dos resultados obtidos em todos os levantamentos.

$$
V M=\frac{\sum_{i}^{n} v_{i}}{n}
$$

onde:

$V_{i}=$ valor da variável no levantamento $i$

$\mathrm{n}=$ número de levantamentos realizados

\subsection{2. Área abaixo da curva de progresso da doença (AUDPC)}

Para cada ciclo da cultura determinou-se a área abaixo da curva de progresso da doença (AUDPC) em função de cada variável, segundo a equação proposta por Campbell e Madden (1990) :

$$
A U D P C=\sum_{i}^{n-1}\left(\frac{y_{i}+y_{i+1}}{2}\right) *\left(t_{i+1}-t_{i}\right)
$$

onde:

$\mathrm{n}=$ número total de levantamento no ciclo

$y_{i}=$ quantidade de doença no levantamento $i$

$t_{i}=$ tempo no levantamento $i$

Como os períodos de levantamento foram diferentes para cada ciclo da cultura, o valor da AUDPC de cada ciclo foi dividido pelo número de dias decorridos entre o $1^{\circ}$ e último levantamentos, proporcionando a obtenção de um valor médio diário que permite a comparação da incidência da doença entre os ciclos (Fry, 1977).

Os valores de AUDPC para as diferentes variáveis foram comparados para determinar aquela que proporciona a melhor distinção das variedades em 
relação à incidência da doença. A comparação através do Teste $F$ levou em consideração os valores obtidos em cada ciclo da cultura, bem como as médias resultantes de dois ou mais ciclos consecutivos.

A opção de se trabalhar com a AUDPC das variáveis e não apenas com os valores cumulativos destas advém principalmente do fato da AUDPC incorporar um importante fator de determinação da resistência, o período de latência. Para caracterizar tal fato basta analisar a situação de três variedades hipotéticas ( $A, B$ e $C$ ), cuja incidência da doença foi expressa em número de plantas doentes, em quatro levantamentos consecutivos, realizados em intervalos de 30 dias:

\begin{tabular}{|c|c|c|c|c|c|}
\hline \multicolumn{6}{|c|}{ Levantamento } \\
\hline Variedade & $1^{0}$ & $2^{0}$ & $3^{\circ}$ & $4^{0}$ & AUDPC* \\
\hline $\bar{A}$ & 0 & 0 & 0 & 50 & 8,3 \\
\hline B & 0 & 5 & 25 & 50 & 18,3 \\
\hline C & 25 & 40 & 50 & 50 & 42,5 \\
\hline
\end{tabular}

* Valor diário

Durante os 90 dias decorridos entre $\circ 1^{\circ}$ e o $4^{\circ}$ levantamentos, as três variedades apresentaram o mesmo número acumulado de plantas doentes, sugerindo que as mesmas apresentam a mesma reação ao patógeno. Contudo, quando a doença é avaliada em função da AUDPC, a variedade $C$ apresenta um valor bastante superior à $B$, que por sua vez é superior à $A$. Neste caso, a diferença ocorreu em função do número de plantas infectadas em cada levantamento, ou seja, em função dos diferentes períodos de latência $(A>B>C)$, sugerindo uma suscetibilidade crescente da variedade $A$ para a variedade $C$.

\subsection{Estimativa de dano}

A estimativa do dano foi realizada em função da diferença de peso observada entre as plantas sadias e doentes. Por ocasião de cada corte, para cada touceira de cada variedade, era realizada a contagem do número de perfilhos industrializáveis e, em seguida, os mesmos eram pesados. Para estimar as reduções de produção, primeiramente separou-se para cada variedade as 
touceiras doentes das sadias. Obteve-se a porcentagem de plantas doentes $(\operatorname{ATD}(\%))$, assim como a diferença média de peso entre as sadias e doentes $(\operatorname{Dif}(\%))$. O dano (Dano(\%)) foi então considerado como o produto da porcentagem de touceiras com carvão (ATD(\%)) pela diferença média de peso entre as touceiras sadias e doentes. Além disso, obteve-se uma variável para avaliar o dano no campo, o ID(\%), ou seja, o índice de redução de produção para cada $1 \%$ de touceiras infectadas.

$$
\operatorname{ATD}(\%)=\left(\frac{N T D}{N T T}\right) * 100
$$

onde:

NTD = número de touceiras doentes

$\mathrm{NTT}$ = número total de touceiras

$\operatorname{Dif}(\%)=\left(\frac{\text { PMTS }- \text { PMTD }}{\text { PMTS }}\right) * 100$

onde:

PMTS = peso médio das touceiras sadias

PMTD = peso médio das touceiras doentes

$\operatorname{Dano}(\%)=\left(\frac{A T D(\%) \star \operatorname{Dif}(\%)}{100}\right)$

$\mathrm{ID}(\%)=\left(\frac{\mathrm{Dano}(\%)}{\operatorname{ATD}(\%)}\right)$

Por meio de regressão linear e não-linear, o dano médio em cada ciclo foi correlacionado com a AUDPC diária obtida a partir das variáveis PATDP, PAPDP e PAPDT, permitindo a construção de equações para determinar o valor médio do incremento de Dano(\%) em função da incidência de doença nas variedades testadas. 


\section{RESULTADOS E DISCUSSÃO}

As variáveis analisadas nos quatro ciclos da cultura estão apresentadas, sem análise estatística, nos anexos 2 a 26.

Os valores de PTRAT(\%) e CV(\%) obtidos no Teste $\mathrm{F}$ para as variáveis de intensidade de doença foram muito semelhantes nos quatro ciclos da cultura, quando calculados em função de VM e AUDPC. Como os valores obtidos em função da AUDPC representam valores diários, eles foram preferidos pois permitem a comparação da intensidade de doença entre os ciclos da cultura. Portanto, os resultados discutidos são aqueles referentes a AUDPC.

\subsection{Cana-planta}

\subsubsection{Avaliação da incidência de doença}

As quatro variáveis calculadas na cana-planta em ordem crescente de valores de PTRAT(\%) foram: PATDP, PAPDT, PAPDP e PATMP (Tabela 3). Para cada variedade, as variáveis de perfilhos doentes acumulados, PAPDP e PAPDT apresentaram semelhante evolução nos quatro levantamentos da cana-planta (Figura 1). Na média das 18 variedades, a AUDPC para PAPDT foi ligeiramente superior àquela obtida com PAPDP (Tabela 3). Para a maioria das variedades, a evolução da doença medida pela variável PATDP superou as demais (Figura 1 e Tabela 3), apresentando valores aproximadamente $50 \%$ superiores à porcentagem de perfilhos doentes por parcela ou por touceira. 


\subsubsection{Avaliação de dano}

Foi observada alta correlação entre os valores de AUDPC e o dano para as três variáveis analisadas: PATDP, PAPDP e PAPDT. A variável PATDP apresentou o maior coeficiente de determinação $\left(R^{2}=0,97\right.$, Figura 2$)$. Em termos médios verificou-se que para cada $1 \%$ de AUDPC para touceiras com carvão, ocorreu um dano igual a $0,91 \%$ em cana-planta (Figura 2). A redução no peso das touceiras doentes ocorreu em função da diminuição do número médio de perfilhos industrializáveis (NMPI) destas. Os valores médios de touceiras doentes (ATD(\%)) e Dano(\%) foram, respectivamente, 17,39 \% e 13,83 \% (Tabela 4). 


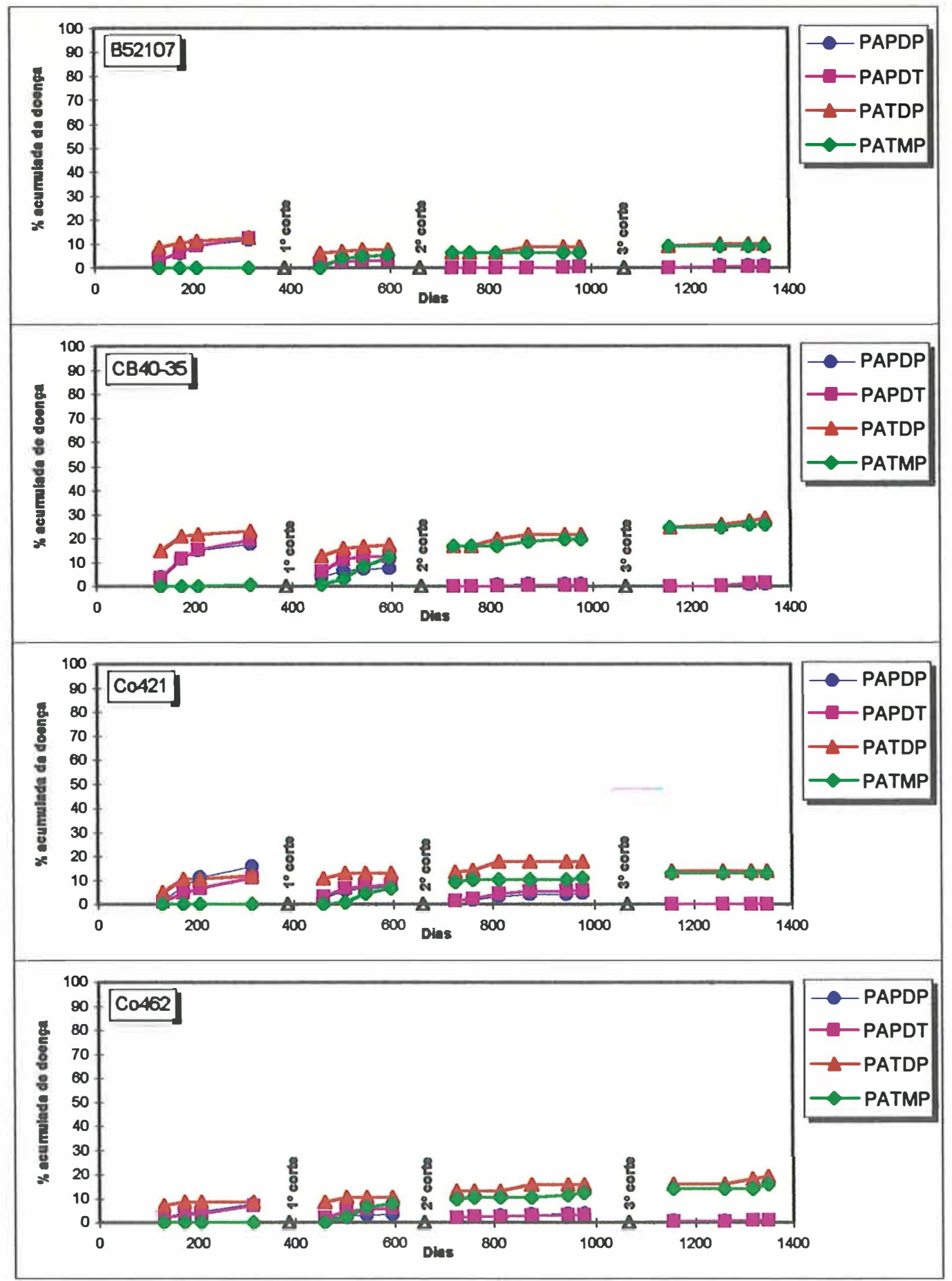

Figura 1 - Curva de progresso da doença em função de quatro variáveis de incidência do carvão, porcentagem acumulada de: perfilhos doentes por parcela (PAPDP), perfilhos doentes por touceira (PAPDT), touceiras doentes por parcela (PATDP) e touceiras mortas por parcela (PATMP), nos quatro ciclos da cultura. 


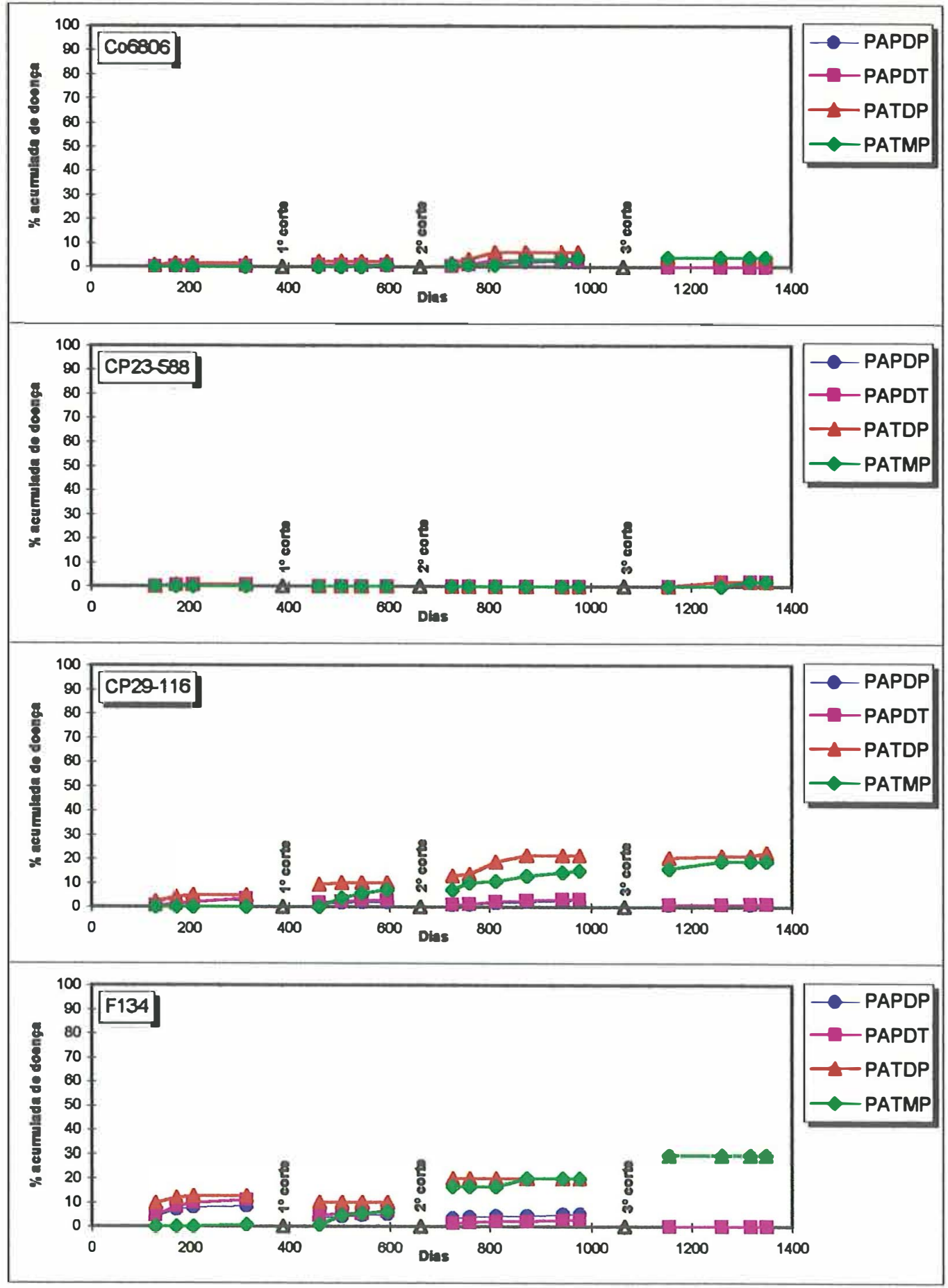

Figura 1 - (Continuação) 


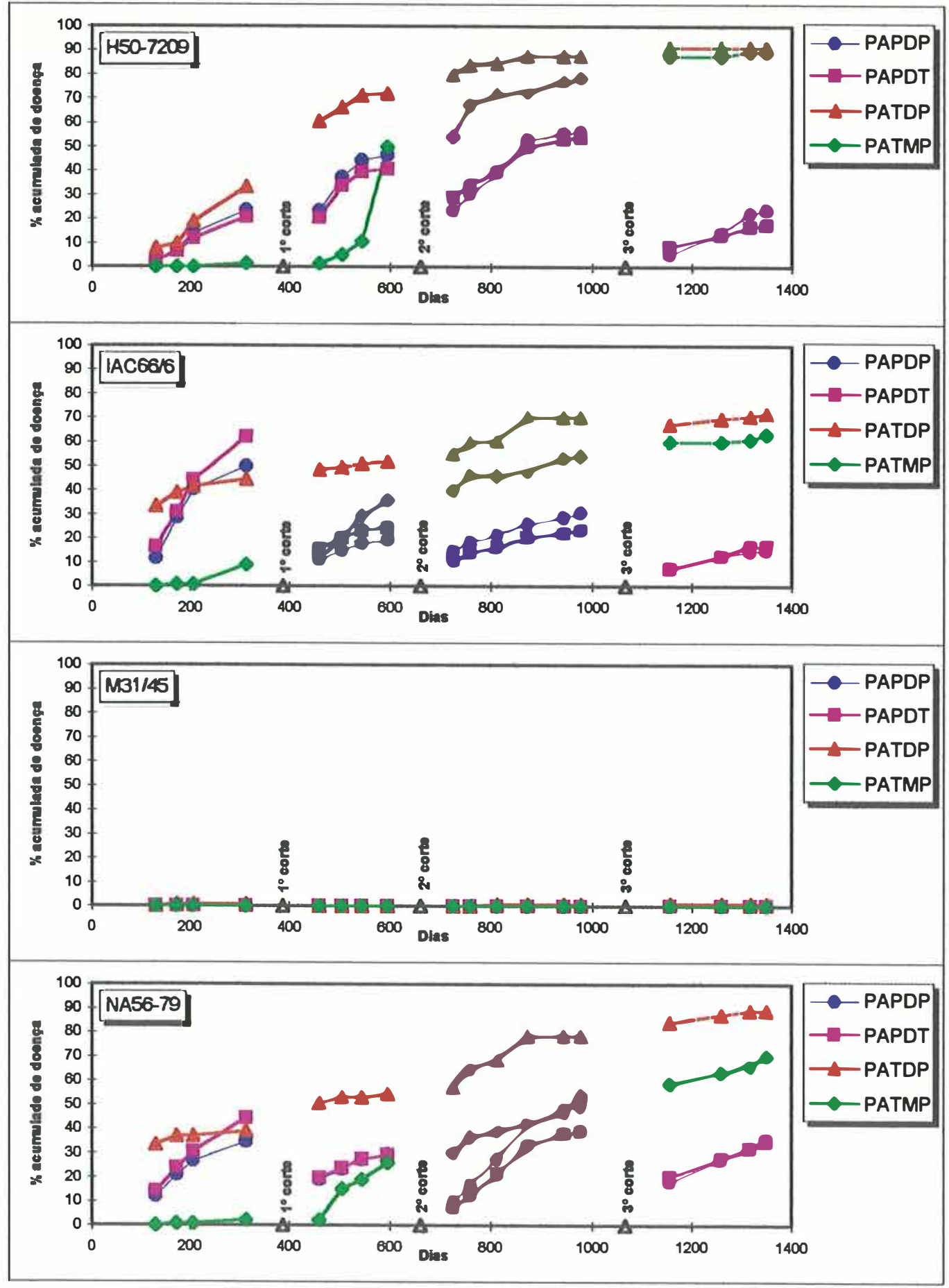

Figura 1 - (Continuação) 


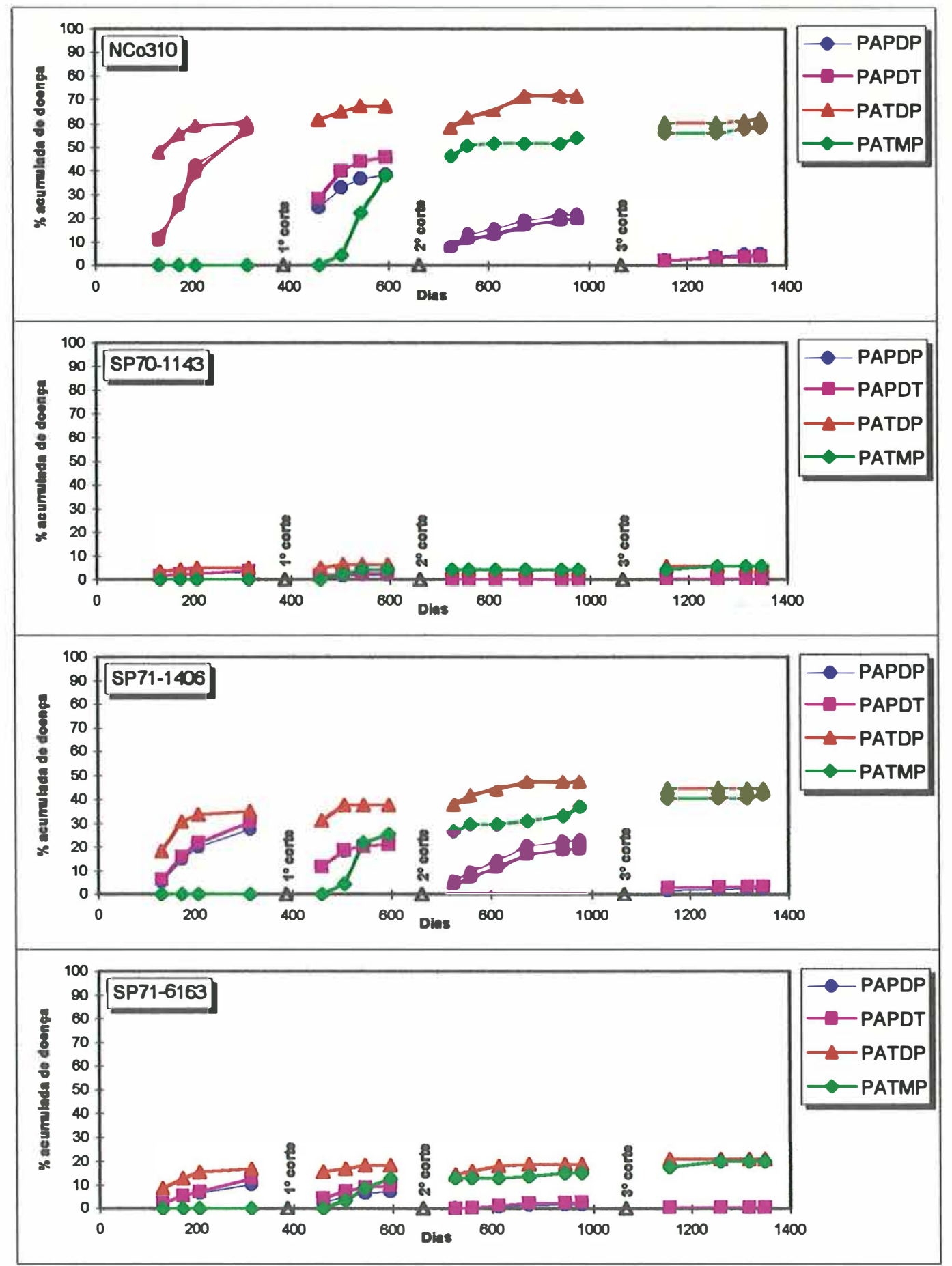

Figura 1 - (Continuação) 


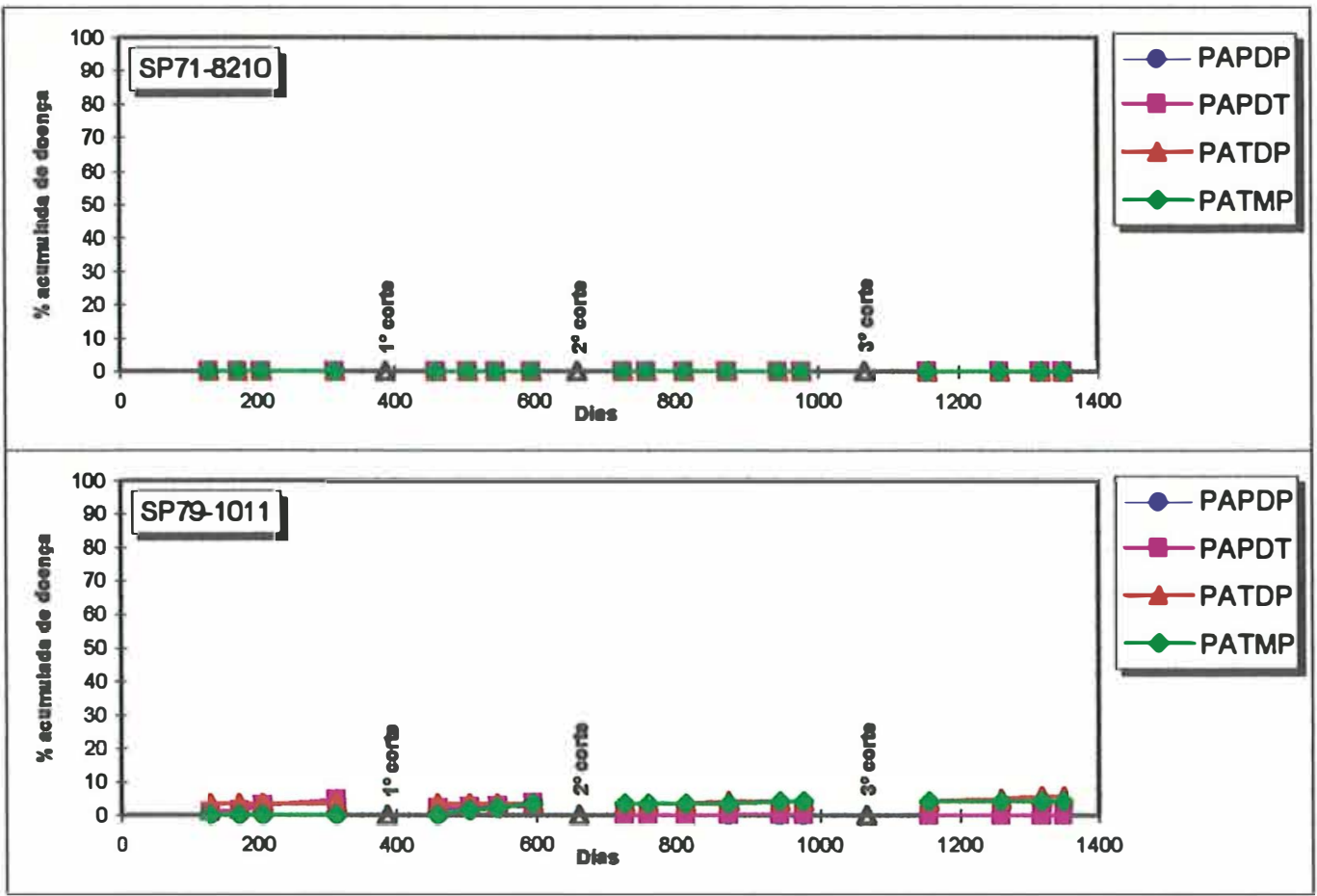

Figura 1 - (Continuação) 
Tabela 3 - Comparação entre a média de incidência acumulada de doença (valor médio (VM) e área abaixo da curva de progresso da doença (AUDPC)) para quatro variáveis de incidência de doença (porcentagem acumulada de: touceiras doentes por parcela (PATDP), perfilhos doentes por touceiras (PAPDT), perfilhos doentes por parcela (PAPDP), touceiras mortas por parcela (PATMP)), obtidas na cana-planta.

\begin{tabular}{|c|c|c|c|c|c|c|c|c|}
\hline \multirow[b]{2}{*}{ Variável } & \multicolumn{4}{|c|}{$\overline{\text { VM }}$} & \multicolumn{4}{|c|}{ AUDPC } \\
\hline & Média & CV(\%) & FTRAT $^{2}$ & PTRAT $(\%)^{3}$ & Média & CV(\%) & FTRAT $^{2}$ & PTRAT(\%) \\
\hline PATDP & 14,745 & 39,412 & 29,769 & 0,857 & 15,470 & 38,635 & 30,011 & 0,847 \\
\hline PAPDT & 10,065 & 48,678 & 23,694 & 1,196 & 11,431 & 47,852 & 24,419 & 1,145 \\
\hline PAPDP & 9,561 & 46,443 & 23,812 & 1,187 & 10,918 & 46,147 & 24,241 & 1,157 \\
\hline PATMP & 0,232 & 171,503 & 10,077 & 4,065 & 0,270 & 172,086 & 10,004 & 4,106 \\
\hline
\end{tabular}

1 - CV $(\%)=$ coeficiente de variação $(\%)$

2 - FTRAT $=$ Distribuição $F$ de Snedecor

3 - PTRAT $(\%)=$ Probabilidade porcentual de erro ao admitir que existe pelo menos um contraste significativo entre as variáveis para as 18 variedades do experimento

Tabela 4 - Danos provocados pelo carvão na cana-planta.

\begin{tabular}{|c|c|c|c|c|c|c|c|c|}
\hline \multirow[b]{2}{*}{ Variedade } & \multirow[b]{2}{*}{ ATD $(\%)^{3}$} & \multicolumn{2}{|c|}{$P M^{1}$} & \multicolumn{2}{|c|}{$\mathrm{NMPI}^{2}$} & \multirow[b]{2}{*}{$\operatorname{Dif}(\%)^{4}$} & \multirow[b]{2}{*}{$\operatorname{Dano}(\%)^{5}$} & \multirow[b]{2}{*}{$\mathrm{ID}(\%)^{6}$} \\
\hline & & Sadias & Doentes & Sadias & Doentes & & & \\
\hline $\bar{B} 52107$ & 12,590 & 3,820 & 1,300 & 4,130 & 2,000 & 65,969 & 8,305 & 0,660 \\
\hline CB40-35 & 22,920 & 4,890 & 1,410 & 5,670 & 2,520 & 71,166 & 16,311 & 0,712 \\
\hline Co421 & 11,890 & 3,720 & 0,310 & 5,520 & 2,240 & 91,667 & 10,899 & 0,917 \\
\hline Co462 & 8,330 & 4,040 & 0,780 & 6,200 & 4,500 & 80,693 & 6,722 & 0,807 \\
\hline Co6806 & 1,400 & 5,250 & 2,550 & 7,260 & 6,000 & 51,429 & 0,720 & 0,514 \\
\hline CP23-588 & 0,690 & 3,120 & 0,000 & 3,820 & 0,000 & 100,000 & 0,690 & 1,000 \\
\hline CP29-116 & 4,900 & 4,060 & 0,740 & 5,150 & 3,290 & 81,773 & 4,007 & 0,818 \\
\hline F134 & 12,500 & 3,780 & 0,860 & 4,790 &, 060 & 77,249 & 9,656 & 0,772 \\
\hline H50-7209 & 33,330 & 4,560 & 3,250 & 4,420 & 4,520 & 28,728 & 9,575 & 0,287 \\
\hline IAC66/6 & 44,440 & 2,810 & 0,440 & 4,420 & 0,810 & 84,342 & 37,481 & 0,843 \\
\hline M31/45 & 0,690 & 5,190 & 3,600 & 5,600 & 4,000 & 30,636 & 0,211 & 0,306 \\
\hline NA56-79 & 38,890 & 4,740 & 1,020 & 5,430 & 3,290 & 78,481 & 30,521 & 0,785 \\
\hline NCo310 & 60,420 & 4,870 & 0,400 & 8,000 & 1,370 & 91,786 & 55,457 & 0,918 \\
\hline SP70-1143 & 4,900 & 5,550 & 2,440 & 6,850 & 4,140 & 56,036 & 2,746 & 0,560 \\
\hline SP71-1406 & 34,970 & 3,820 & 1,090 & 4,260 & 3,040 & 71,466 & 24,992 & 0,715 \\
\hline SP71-6163 & 16,670 & 3,180 & 0,540 & 5,330 & 2,880 & 83,019 & 13,839 & 0,830 \\
\hline SP71-8210 & 0,000 & 2,880 & 0,000 & 4,460 & 0,000 & - & - & - \\
\hline SP79-1011 & 3,500 & 5,070 & 0,660 & 5,800 & 4,600 & 86,982 & 3,044 & 0,870 \\
\hline Média & 17,391 & 4,186 & 1,188 & 5,395 & 2,848 & 72,437 & 13,834 & 0,724 \\
\hline
\end{tabular}

1 - PM = peso $(\mathrm{Kg})$ médio das touceiras

2 - NMPI = número médio de perfilhos industrializáveis por touceira

$3-\mathrm{ATD}(\%)=$ porcentagem de plantas doentes

4 - Dif(\%) = diferença média de peso entre touceiras sadias e doentes

5 - Dano(\%) = reduçāo de produção provocada pelo carvão

6 - ID(\%) = indice de reduçāo da produçāo para cada $1 \%$ de touceiras infectadas 


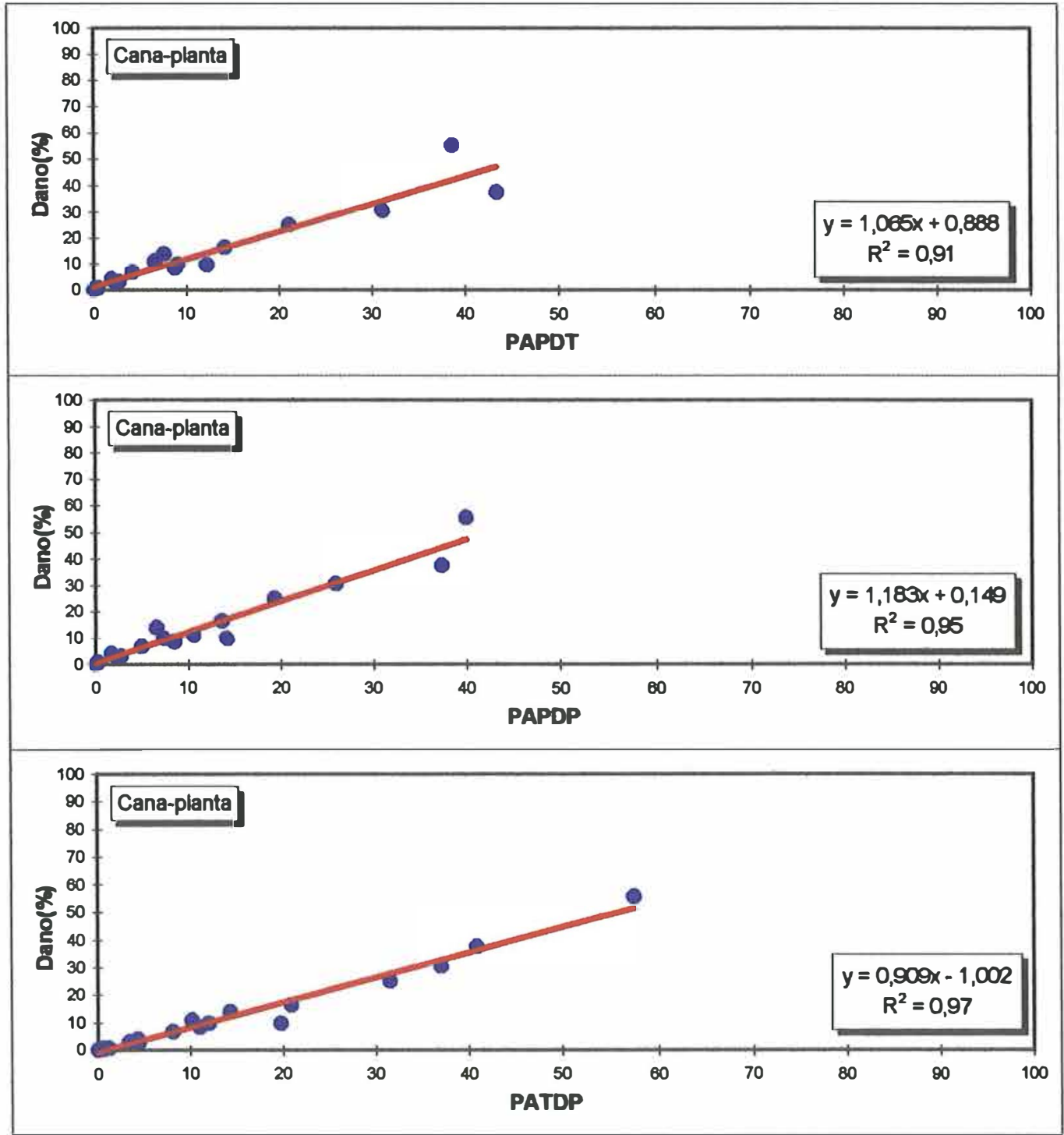

Figura 2 - Relação entre valores da área abaixo da curva de progresso da doença (AUDPC) para três variáveis de incidência percentual acumulada de doença (perfilhos doentes por touceira (PAPDT), perfilhos doentes por parcela (PAPDP) e touceiras doentes por parcela (PATDP)) e o dano (Dano(\%)), na cana-planta. 


\subsection{Primeira soca}

\subsubsection{Avaliação da incidência de doença}

Na primeira soca, as variáveis que apresentaram os seis menores valores de PTRAT(\%) foram: PNPDP, PAPDP, PNTDP, PNPDT, PAPDT e PATDP (Tabela 5). A exemplo do observado na cana-planta, a evolução da doença ao longo dos levantamentos foi semelhante quando avaliada em função da PAPDP e PAPDT (Figura 1). Os valores de AUDPC para PAPDP e PAPDT para a média das 18 variedades foram 6,80 e 7,59, respectivamente (Tabela 5). A evolução destas duas variáveis na maioria dos casos foi inferior àquela observada para PATDP. Observou-se uma acentuada evolução nos valores de PATMP para cinco variedades: H50-7209, IAC66/6, NA56-79, NCo310 e SP71-1406 (Figura 1), cujo valor médio foi $4,97 \%$ (Tabela 5). O valor médio da PATDP foi 14,97, correspondendo a aproximadamente o dobro dos valores observados para PAPDP e PAPDT.

Em relação a cana-planta, os valores de PAPDP, PAPDT e PATDP diminuíram, enquanto que PATMP aumentou (Tabela 11).

\subsubsection{Avaliação de dano}

Foram observadas altas correlações entre os valores de AUDPC para as três variáveis e o dano, com coeficiente de determinação igual a 0,98 para PATDP e PAPDT. Na primeira soca para cada $1 \%$ de AUDPC para PATDP observou-se um dano igual a 1,11\% (Figura 3 ). Para a média das 18 variedades a ATD(\%) foi $21,12 \%$ e o Dano(\%) foi $20,54 \%$ (Tabela 6), representando um aumento de $21,33 \%$ e $48,23 \%$ em relação ao observado na cana-planta. 
Tabela 5 - Comparação entre a média de incidência acumulada e não acumulada de doença (valor médio (VM) e área abaixo da curva de progresso da doença $(A U D P C)$ ) para sete variáveis de incidência de doença (porcentagem acumulada de: touceiras doentes por parcela (PATDP), perfilhos doentes por touceiras (PAPDT), perfilhos doentes por parcela (PAPDP), touceiras mortas por parcela (PATMP) e porcentagem não acumulada de: touceiras doentes por parcela (PNTDP), perfilhos doentes por touceiras (PNPDT), perfilhos doentes por parcela (PNPDP)), obtidas na primeira soca.

\begin{tabular}{l|rrrr|rrrr}
\hline & \multicolumn{4}{|c|}{ VM } & \multicolumn{4}{c}{ AUDPC $^{\text {Variável }}$} \\
\cline { 2 - 9 } & Média & CV(\%) $^{\mathbf{1}}$ & FTRAT $^{\mathbf{2}}$ & PTRAT(\%) $^{\mathbf{3}}$ & Média & CV(\%) & FTRAT $^{\mathbf{2}}$ & PTRAT(\%) $^{\mathbf{3}}$ \\
\hline PNPDP & 8,340 & 32,281 & 60,954 & $\mathbf{0 , 2 9 8}$ & 6,329 & 31,806 & 62,982 & 0,284 \\
PAPDP & 9,039 & 35,953 & 53,407 & 0,362 & 6,803 & 36,266 & 52,580 & 0,371 \\
PNTDP & 18,558 & 32,567 & 50,220 & 0,397 & 13,770 & 32,322 & 50,673 & 0,392 \\
PNPDT & 8,666 & 37,179 & 43,149 & 0,496 & 6,614 & 35,386 & 47,331 & 0,433 \\
PAPDT & 10,072 & 35,855 & 45,703 & 0,456 & 7,594 & 35,835 & 45,762 & 0,455 \\
PATDP & 20,246 & 34,577 & 43,818 & 0,485 & 14,965 & 34,496 & 43,855 & 0,485 \\
PATMP & 6,694 & 54,422 & 15,559 & 2,196 & 4,973 & 58,617 & 13,028 & 2,830 \\
\hline
\end{tabular}

1 - CV $(\%)=$ coeficiente de variaçāo $(\%)$

2 - FTRAT $=$ Distribuição $F$ de Snedecor

3 - PTRAT $(\%)=$ Probabilidade porcentual de erro ao admitir que existe pelo menos um contraste significativo entre as variáveis para as 18 variedades do experimento 
Tabela 6 - Danos provocados pelo carvão na primeira soca.

\begin{tabular}{|c|c|c|c|c|c|c|c|c|}
\hline \multirow[b]{2}{*}{ Variedade } & \multirow[b]{2}{*}{$\operatorname{ATD}(\%)^{3}$} & \multicolumn{2}{|c|}{$\mathrm{PM}^{4}$} & \multicolumn{2}{|c|}{$\mathrm{NMPI}^{2}$} & \multirow[b]{2}{*}{$\operatorname{Dif}(\%)^{4}$} & \multirow[b]{2}{*}{ Dano(\%) } & \multirow[b]{2}{*}{$I D(\%)^{8}$} \\
\hline & & Sadias & Doentes & Sadias & Doentes & & & \\
\hline$\overline{\mathrm{B} 52107}$ & $\overline{7,460}$ & 6,180 & 1,460 & 6,250 & 2,000 & 76,375 & 5,698 & 0,764 \\
\hline CB40-35 & 16,910 & 7,250 & 0,580 & 7,720 & 0,610 & 92,000 & 15,557 & 0,920 \\
\hline Co421 & 12,770 & 7,440 & 0,910 & 8,460 & 1,780 & 87,769 & 11,208 & 0,878 \\
\hline Co462 & 10,420 & 7,330 & 1,390 & 8,070 & 1,400 & 81,037 & 8,444 & 0,810 \\
\hline Co6806 & 2,100 & 6,950 & 0,900 & 9,220 & 3,330 & 87,050 & 1,828 & 0,871 \\
\hline CP23-588 & 0,000 & 4,640 & 0,000 & 4,880 & 0,000 & - & - & - \\
\hline CP29-116 & 9,860 & 6,790 & 1,600 & 8,340 & 2,930 & 76,436 & 7,537 & 0,764 \\
\hline F134 & 9,770 & 5,470 & 0,200 & 6,390 & 0,850 & 96,344 & 9,413 & 0,963 \\
\hline H50-7209 & 72,140 & 6,450 & 1,290 & 6,620 & 1,470 & 80,000 & 57,712 & 0,800 \\
\hline IAC66/6 & 51,300 & 6,990 & 1,770 & 7,880 & 2,000 & 74,678 & 38,310 & 0,747 \\
\hline M31/45 & 0,000 & 9,210 & 0,000 & 8,180 & 0,000 & - & - & - \\
\hline NA56-79 & 54,200 & 7,010 & 2,510 & 7,250 & 4,200 & 64,194 & 34,793 & 0,642 \\
\hline NCo310 & 67,630 & 10,820 & 1,330 & 14,600 & 1,840 & 87,708 & 59,317 & 0,877 \\
\hline SP70-1143 & 6,290 & 8,360 & 0,560 & 9,630 & 0,780 & 93,301 & 5,869 & 0,933 \\
\hline SP71-1406 & 37,680 & 5,920 & 0,650 & 7,150 & 1,810 & 89,020 & 33,543 & 0,890 \\
\hline SP71-6163 & 18,180 & 5,890 & 0,930 & 7,810 & 1,920 & 84,211 & 15,309 & 0,842 \\
\hline SP71-8210 & 0,000 & 4,350 & 0,000 & 5,310 & 0,000 & - & - & - \\
\hline SP79-1011 & 3,500 & 7,710 & 0,000 & 7,600 & 0,000 & 100,000 & 3,500 & 1,000 \\
\hline Média & 21,123 & 6,931 & 0,893 & 7,853 & 1,496 & 84,675 & 20,536 & 0,847 \\
\hline
\end{tabular}

1 - PM = peso $(\mathrm{Kg})$ médio das touceiras

2 - NMPI = número médio de perfilhos industrializáveis por touceira

3 - $A T D(\%)=$ porcentagem de plantas doentes

4 - Dif( $\%)=$ diferença média de peso entre touceiras sadias e doentes

5 - Dano(\%) = redução de produção provocada pelo carvão

- $6-I D(\%)=$ indice de redução da produção para cada $1 \%$ de touceiras infectadas 


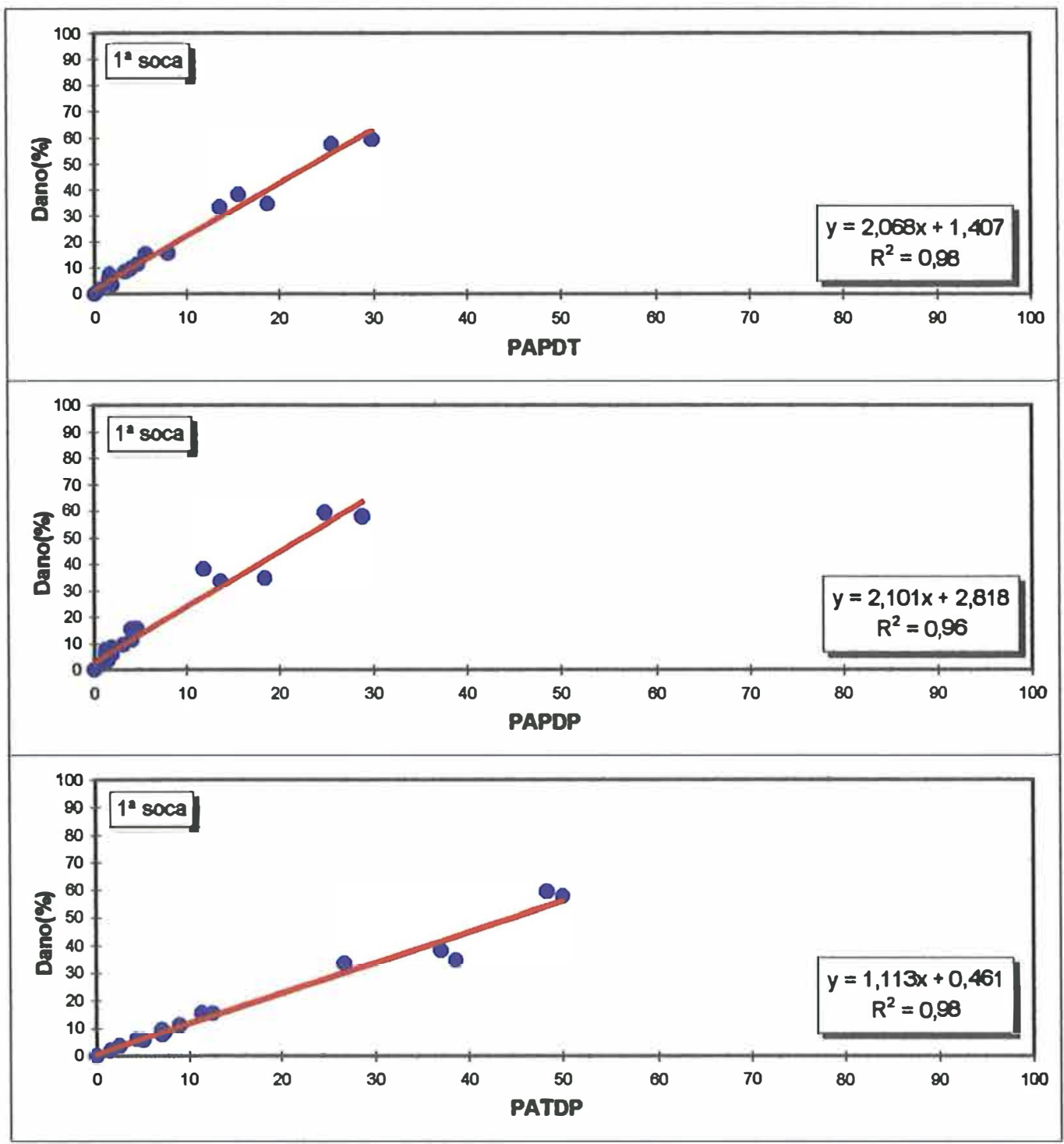

Figura 3 - Relação entre valores da área abaixo da curva de progresso da doença (AUDPC) para três variáveis de incidência percentual acumulada de doença (perfilhos doentes por touceira (PAPDT), perfilhos doentes por parcela (PAPDP) e touceiras doentes por parcela (PATDP)) e o dano (Dano(\%)), na primeira soca. 


\subsection{Segunda soca}

\subsubsection{Avaliação da incidência de doença}

$\mathrm{Na}$ segunda soca os seis menores valores de PTRAT(\%) foram observados para as seguintes variáveis: PATDP, PATMP, PNPDP, PNTDP, PAPDP e PAPDT (Tabela 7). Neste ciclo, PAPDP e PAPDT continuaram a apresentar evolução semelhante dentro de cada variedade. PATMP apresentou crescimento em relação ao ciclo anterior, principalmente para as variedades $\mathrm{H} 50$ 7209, IAC66/6, NA56-79, NCo310 e SP71-1406 (Figura 1). Para todas as variedades, PATDP foi superior às demais variáveis cumulativas. Para a média das 18 variedades, PAPDP e PAPDT apresentaram valores semelhantes, iguais a 8,45 e 7,41 , respectivamente. $O$ valor médio de PATDP foi igual a 25,77 e de PATMP, 18,94 (Tabela 7).

Em relação ao ciclo anterior observou-se, para a média das variedades, uma diminuição no valor de PAPDT e um aumento nos valores de PATDP, PAPDP e PATMP (Tabela 11).

\subsubsection{Avaliação de dano}

Para a média das 18 variedades, ATD(\%) foi igual a $27,16 \%$ e o Dano(\%) igual a $24,19 \%$ (Tabela 8). Para estas duas variáveis ocorreu um aumento de 28,91 e $18,05 \%$, respectivamente.

Foi observada alta correlação entre os valores de AUDPC para PATDP e o dano, com $R^{2}=0,99$. Para cada $1 \%$ de AUDPC para PATDP ocorreu dano proporcional a $0,80 \%$ (Figura 4). Para as variáveis PAPDP e PAPDT observou-se menores valores de $R^{2}$ que foram iguais a 0,88 e 0,85 , respectivamente. 
Tabela 7 - Comparação entre a média de incidência acumulada e não acumulada de doença (valor médio (VM) e área abaixo da curva de progresso da doença (AUDPC)) para sete variáveis de incidência de doença (porcentagem acumulada de: touceiras doentes por parcela (PATDP), perfilhos doentes por touceiras (PAPDT), perfilhos doentes por parcela (PAPDP), touceiras mortas por parcela (PATMP) e porcentagem não acumulada de: touceiras doentes por parcela (PNTDP), perfilhos doentes por touceiras (PNPDT), perfilhos doentes por parcela (PNPDP)), obtidas na segunda soca.

\begin{tabular}{|c|c|c|c|c|c|c|c|c|}
\hline \multirow[b]{2}{*}{ Variável } & \multicolumn{4}{|c|}{$\overline{V M}$} & \multicolumn{4}{|c|}{ AUDPC } \\
\hline & Média & $\mathrm{CV}(\%)^{1}$ & FTRAT $^{2}$ & PTRAT(\%) & Média & CV $(\%)^{1}$ & FTRAT $^{2}$ & PTRAT(\%) \\
\hline PATDP & 25,395 & 30,253 & 52,476 & 0,372 & 25,770 & 30,165 & 52,450 & 0,372 \\
\hline PATMP & 18,837 & 34,925 & 39,820 & 0,559 & 18,936 & 35,265 & 39,470 & 566 \\
\hline PNPDP & 5,520 & 58,771 & 29,672 & 0,861 & 5,628 & 59,344 & 29,473 & 0,870 \\
\hline PNTDP & 14,448 & 43,624 & 32,814 & 0,743 & 13,581 & 48,308 & 28,137 & 0,931 \\
\hline PAPDP & 8,123 & 62 & 25,669 & 1,064 & 8,452 & 63,129 & 24,914 & 1,112 \\
\hline PAPDT & 7,143 & 66,184 & 24,327 & 1 & 7,4 & 66,361 & & 1,180 \\
\hline PNPDT & 4,888 & 65,052 & 24,296 & 1,153 & 4,988 & 66,409 & 23,065 & 1,244 \\
\hline
\end{tabular}

$1-\mathrm{CV}(\%)=$ coeficiente de variaçāo $(\%)$

2 - FTRAT $=$ Distribuição $F$ de Snedecor

3 - PTRAT(\%) = Probabilidade porcentual de erro ao admitir que existe pelo menos um contraste significativo entre as variáveis para as 18 variedades do experimento 
Tabela 8 - Danos provocados pelo carvão na segunda soca.

\begin{tabular}{|c|c|c|c|c|c|c|c|c|}
\hline \multirow[b]{2}{*}{ Variedade } & \multirow[b]{2}{*}{$\operatorname{ATD}(\%)^{3}$} & \multicolumn{2}{|c|}{$\mathrm{PM}^{1}$} & \multicolumn{2}{|c|}{$\mathrm{NMPI}^{2}$} & \multirow[b]{2}{*}{$\operatorname{Dif}(\%)^{4}$} & \multirow[b]{2}{*}{ Dano(\%) } & \multirow[b]{2}{*}{$\operatorname{ID}(\%)^{6}$} \\
\hline & & Sadias & Doentes & Sadias & Doentes & & & \\
\hline$\overline{B 52107}$ & 8,620 & 3,470 & 1,490 & 4,600 & 2,500 & 57,061 & 4,919 & 0,571 \\
\hline CB40-35 & 21,430 & 4,490 & 0,450 & 5,950 & 0,710 & 89,978 & 19,282 & 0,900 \\
\hline Co421 & 16,510 & 4,270 & 0,950 & 7,510 & 1,610 & 77,752 & 12,837 & 0,778 \\
\hline Co462 & 15,380 & 4,670 & 1,340 & 7,020 & 2,110 & 71,306 & 10,967 & 0,713 \\
\hline Co6806 & 6,500 & 5,160 & 0,410 & 7,780 & 0,750 & 92,054 & 5,984 & 0,921 \\
\hline CP23-588 & 0,000 & 2,790 & 0,000 & 4,890 & 0,000 & - & - & - \\
\hline CP29-116 & 21,280 & 5,640 & 1,370 & 7,260 & 1,930 & 75,709 & 16,111 & 0,757 \\
\hline F134 & 17,860 & 2,320 & 0,000 & 4,670 & 0,000 & 100,000 & 17,860 & 1,000 \\
\hline H50-7209 & 87,600 & 1,970 & 0,360 & 4,060 & 0,530 & 81,726 & 71,592 & 0,817 \\
\hline IAC66/6 & 69,000 & 3,880 & 1,270 & 5,770 & 1,810 & 67,268 & 46,415 & 0,673 \\
\hline M31/45 & 0,710 & 4,710 & 2,300 & 7,160 & 8,000 & 51,168 & 0,363 & 0,512 \\
\hline NA56-79 & 78,070 & 6,320 & 1,750 & 7,000 & 2,190 & 72,310 & 56,453 & 0,723 \\
\hline NCo310 & 71,930 & 7,310 & 1,520 & 13,220 & 2,990 & 79,207 & 56,973 & 0,792 \\
\hline SP70-114 & 4,260 & 9,360 & 0,000 & 9,840 & 0,000 & 100,000 & 4,260 & 1,000 \\
\hline SP71-1406 & 46,970 & 5,720 & 0,710 & 7,030 & 1,130 & 87,587 & 41,140 & 0,876 \\
\hline SP71-6163 & 18,570 & 5,190 & 0,250 & 8,540 & 0,500 & 95,183 & 17,675 & 0,952 \\
\hline SP71-8210 & 0,000 & 4,800 & 0,000 & 6,100 & 0,000 & - & - & - \\
\hline SP79-1011 & 4,200 & 8,780 & 0,000 & 7,800 & 0,000 & 100,000 & 4,200 & 1,000 \\
\hline Média & 27,161 & 5,047 & 0,787 & 7,011 & 1,487 & 81,144 & 24,189 & 0,811 \\
\hline
\end{tabular}

1 - $P M=$ peso $(\mathrm{Kg})$ médio das touceiras

2 - NMPI = número médio de perfilhos industrializáveis por toucelra

3 - ATD $(\%)=$ porcentagem de plantas doentes

4 - Dif(\%) = diferença média de peso entre touceiras sadias e doentes

5 - Dano(\%) = redução de produção provocada pelo carvão

$6-\operatorname{ID}(\%)=$ indice de redução da produção para cada $1 \%$ de touceiras infectadas 


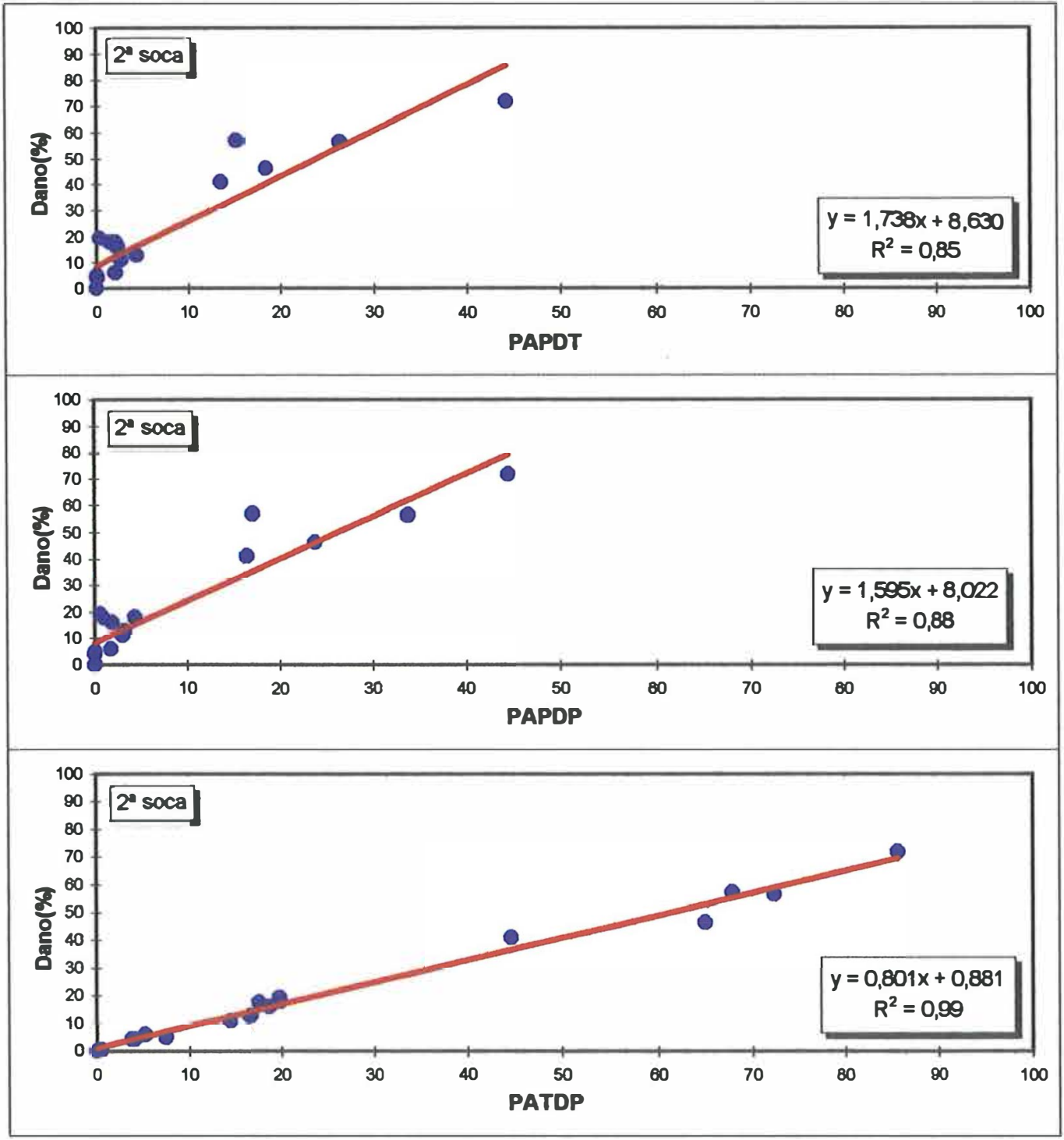

Figura 4 - Relação entre valores da área abaixo da curva de progresso da doença (AUDPC) para três variáveis de incidência percentual acumulada de doença (perfilhos doentes por touceira (PAPDT), perfilhos doentes por parcela (PAPDP) e touceiras doentes por parcela (PATDP)) e o dano (Dano(\%)), na segunda soca. 


\subsection{Terceira soca}

\subsubsection{Avaliação da incidência de doença}

No último estágio da cultura, os seis menores valores de PTRAT(\%) foram: PATDP, PATMP, PNTDP, PNPDT, PNPDP e PAPDT. Entre as variáveis percentuais acumuladas, os valores de PAPDP, PAPDT, PATDP e PATMP foram: 3,$71 ; 3,71 ; 29,48$ e 26,19 , respectivamente (Tabela 9). Para as duas primeiras variáveis ocorreu uma diminuição em relação ao ciclo anterior igual a 56,08 \% e $49,98 \%$. Para as outras duas observou-se aumentos de $14,38 \%$ e $38,29 \%$, respectivamente (Tabela 11 ).

\subsubsection{Avaliação de dano}

$\mathrm{Na}$ terceira soca continuou sendo observada alta correlação entre AUDPC para PATDP e o dano provocado pelo carvão $\left(R^{2}=0,98\right)$. Para cada $1 \%$ de AUDPC para PATDP observou-se um dano de 0,85\% (Figura 5). Os valores médios de $\operatorname{ATD}(\%)$ e Dano(\%) sofreram aumentos de 5,15\% e 11,98\% em relação ao ciclo anterior, atingindo valores iguais a $28,60 \%$ e $27,15 \%$, respectivamente (Tabela 10). Para PAPDP e PAPDT observou-se mudança na relação com o dano.

A regressão linear, apesar de significativa, apresentou coeficientes de correlação baixos $\left(R^{2}=0,60\right.$ e 0,58 , respectivamente para PAPDP e PAPDT). Modelos não-lineares, como o monomolecular $(y=1-a \exp (-b x)$, onde $y$ é o dano, $x$ representa a doença, a e $b$ são parâmetros do modelo (Bergamin Filho, 1995)) retrataram melhor a relação entre AUDPC e dano, neste caso com $R^{2}$ igual a 0,82 e 0,83 . No entanto, o uso destes modelos dificulta o cálculo do dano e sua comparação com o ciclo anterior, onde a relação AUDPC $\times$ dano foi tipicamente linear. Esta mudança implica na rejeição destas variáveis para cálculo de dano nos ciclos de cultura mais avançados. 
Tabela 9 - Comparação entre a média de incidência acumulada e não acumulada de doença (valor médio (VM) e área abaixo da curva de progresso da doença (AUDPC)) para sete variáveis de incidência de doença (porcentagem acumulada de: touceiras doentes por parcela (PATDP), perfilhos doentes por touceiras (PAPDT), perfilhos doentes por parcela (PAPDP), touceiras mortas por parcela (PATMP) e porcentagem não acumulada de: touceiras doentes por parcela (PNTDP), perfilhos doentes por touceiras (PNPDT), perfilhos doentes por parcela (PNPDP)), obtidas na terceira soca.

\begin{tabular}{l|rrrr|rrrr}
\hline & \multicolumn{4}{|c|}{ VM } & \multicolumn{4}{c}{ AUDPC } \\
\cline { 2 - 9 } Variável & Média & CV(\%) $^{\mathbf{1}}$ & FTRAT $^{\mathbf{2}}$ & PTRAT(\%) & Média & CV(\%) $^{\mathbf{1}}$ & FTRAT $^{\mathbf{2}}$ & PTRAT(\%) \\
\hline PATDP & 28,250 & $\mathbf{2 8 , 8 4 9}$ & 53,800 & 0,358 & 29,475 & $\mathbf{2 8 , 8 7 7}$ & 53,996 & 0,356 \\
PATMP & 25,186 & $\mathbf{2 8 , 2 4 0}$ & 55,214 & 0,345 & 26,186 & $\mathbf{2 8 , 6 3 8}$ & 53,757 & 0,359 \\
PNTDP & 10,555 & 40,832 & 36,695 & 0,630 & 11,495 & 39,343 & 38,330 & 0,591 \\
PNPDT & 2,033 & 171,899 & 5,727 & 8,790 & 2,127 & 173,843 & 5,663 & 8,922 \\
PNPDP & 2,264 & 178,678 & 5,304 & 9,726 & 2,377 & 174,754 & 5,529 & 9,209 \\
PAPDT & 3,747 & 176,269 & 5,154 & 10,100 & 3,705 & 175,057 & 5,264 & 9,824 \\
PAPDP & 3,798 & 197,501 & 4,094 & 13,574 & 3,712 & 190,305 & 4,405 & 12,370 \\
\hline
\end{tabular}

1 - CV(\%) = coeficiente de variação (\%)

2 - FTRAT = Distribuição $F$ de Snedecor

3 - PTRAT $(\%)=$ Probabilidade porcentual de erro ao admitir que existe pelo menos um contraste significativo entre as variáveis para as 18 variedades do experimento 
Tabela 10 - Danos provocados pelo carvão na terceira soca.

\begin{tabular}{|c|c|c|c|c|c|c|c|c|}
\hline \multirow[b]{2}{*}{ Variedade } & \multirow[b]{2}{*}{ ATD(\%) ${ }^{3}$} & \multicolumn{2}{|c|}{$P M^{1}$} & \multicolumn{2}{|c|}{ NMPI $^{2}$} & \multirow[b]{2}{*}{$\operatorname{Dif}(\%)^{4}$} & \multirow[b]{2}{*}{ Dano(\%) } & \multirow[b]{2}{*}{$\mathrm{ID}(\%)^{6}$} \\
\hline & & Sadias & Doentes & Sadias & Doentes & & & \\
\hline$\overline{\mathrm{B} 52107}$ & 10,260 & 4,910 & 0,610 & 5,340 & 0,500 & 87,576 & 8,985 & 0,876 \\
\hline CB40-35 & 27,500 & 6,600 & 0,230 & 7,090 & 0,230 & 96,515 & 26,542 & 0,965 \\
\hline Co421 & 12,770 & 6,370 & 0,300 & 9,040 & 0,330 & 95,290 & 12,169 & 0,953 \\
\hline Co462 & 18,450 & 4,600 & 0,840 & 7,100 & 1,580 & 81,739 & 15,081 & 0,817 \\
\hline Co6806 & 4,350 & 7,890 & 0,000 & 10,260 & 0,000 & 100,000 & 4,350 & 1,000 \\
\hline CP23-588 & 1,820 & 5,680 & 0,000 & 7,430 & 0,000 & 100,000 & 1,820 & 1,000 \\
\hline CP29-116 & 22,390 & 5,800 & 1,170 & 8,110 & 1,830 & 79,828 & 17,873 & 0,798 \\
\hline F134 & 25,000 & 5,800 & 0,000 & 7,870 & 0,000 & 100,000 & 25,000 & 1,000 \\
\hline H50-7209 & 91,300 & 0,690 & 0,000 & 2,300 & 0,020 & 100,000 & 91,300 & 1,000 \\
\hline IAC66/6 & 72,220 & 3,960 & 0,610 & 4,440 & 0,750 & 84,596 & 61,095 & 0,846 \\
\hline M31/45 & 0,900 & 6,340 & 0,900 & 8,290 & 2,000 & 85,804 & 0,772 & 0,858 \\
\hline NA56-79 & 88,570 & 5,180 & 1,350 & 6,420 & 1,850 & 73,938 & 65,487 & 0,739 \\
\hline NCo310 & 62,730 & 9,110 & 0,850 & 13,630 & 1,250 & 90,670 & 56,877 & 0,907 \\
\hline SP70-1 & 5,710 & 9,780 & 0,000 & 10,610 & 0,000 & 100,000 & 5,710 & 1,000 \\
\hline SP71-1406 & 44,630 & 5,120 & 0,120 & 7,100 & 0,220 & 97,656 & 43,584 & 0,977 \\
\hline SP71-6163 & 20,660 & 4,000 & 0,020 & 7,780 & 0,080 & 99,500 & 20,557 & 0,995 \\
\hline SP71-8210 & 0,000 & 4,960 & 0,000 & 6,260 & 0,000 & - & - & - \\
\hline SP79-1011 & 5,590 & 8,810 & 2,040 & 8,720 & 2,880 & 76,844 & 4,296 & 0,768 \\
\hline Média & 28,603 & 5,867 & 0,502 & 7,655 & 0,751 & 91,174 & 27,147 & 0,912 \\
\hline
\end{tabular}

1 - PM = peso $(\mathrm{Kg})$ médio das touceiras

2 - NMPI = número médio de perfllhos industrializáveis por touceira

$3-A T D(\%)=$ porcentagem de plantas doentes

4 - Dif(\%) = diferença média de peso entre touceiras sadias e doentes

5 - Dano(\%) = redução de produção provocada pelo carvão

$6-I D(\%)=$ indice de redução da produção para cada $1 \%$ de touceiras infectadas 


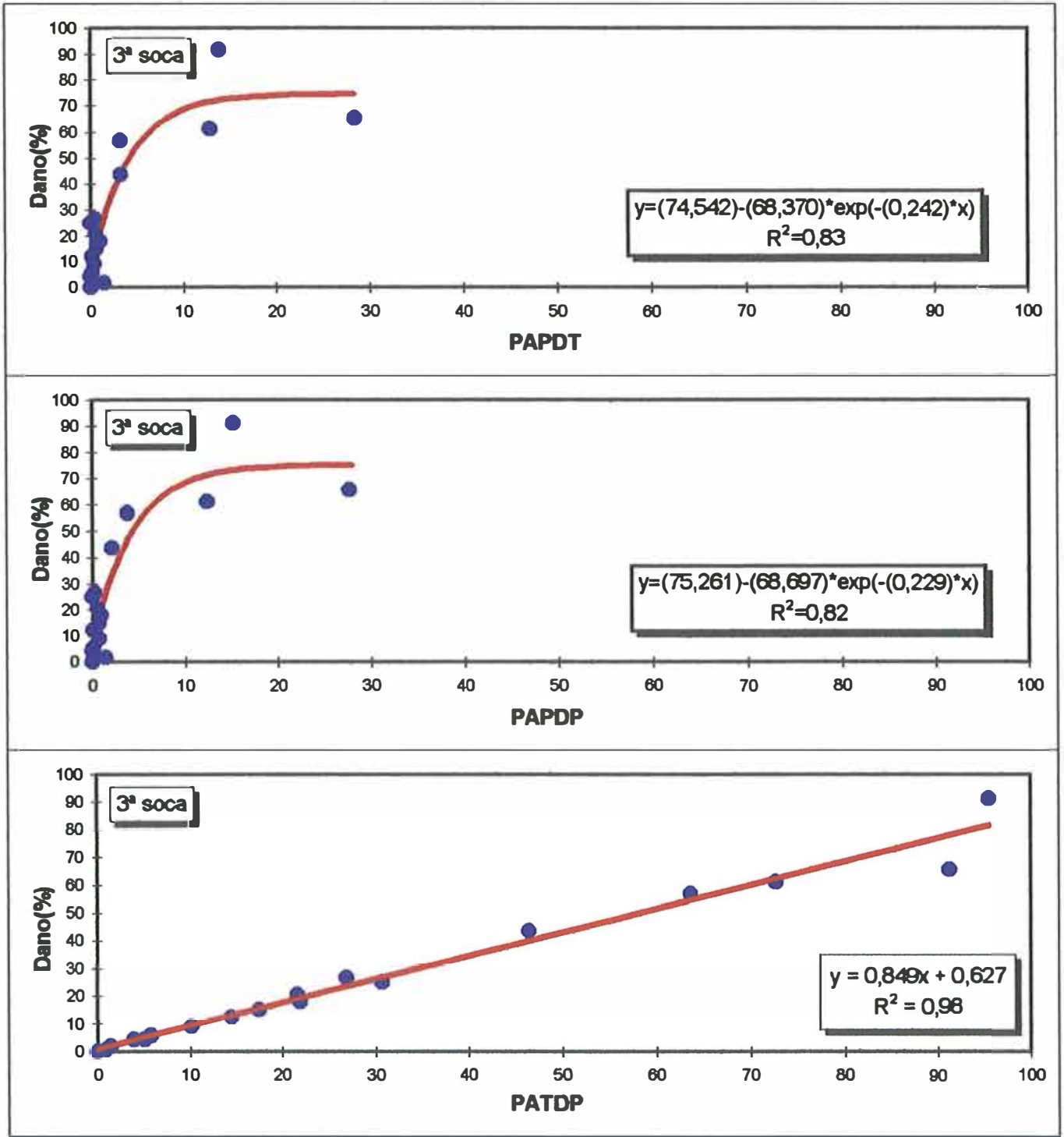

Figura 5 - Relação entre valores da área abaixo da curva de progresso da doença (AUDPC) para três variáveis de incidência percentual acumulada de doença (perfilhos doentes por touceira (PAPDT), perfilhos doentes por parcela (PAPDP) e touceiras doentes por parcela (PATDP)) e o dano (Dano(\%)), na terceira soca. 


\subsection{Geral}

\subsubsection{Avaliação da intensidade de doença}

Com exceção da primeira soca, PATDP foi a variável que permitiu a melhor distinção entre as variedades avaliadas, apresentando os menores valores para PTRAT(\%) e CV(\%) (Tabela 12). As diferenças entre as variedades testadas, quantificadas pela porcentagem de touceiras doentes foram maiores à medida que o número de ciclos avaliados aumentou. $O$ valor de PTRAT(\%) no estádio de cana-planta foi de 0,857, e de 0,481, 0,326 e 0,301 para canaplanta+primeira soca, cana-planta+primeira soca+segunda soca e canaplanta+primeira soca+segunda soca+terceira soca.

$\mathrm{Na}$ média das 18 variedades, os valores de AUDPC para a variável baseada em touceiras doentes foi sempre superior aos valores observados em função de perfilhos doentes. Durante os quatro ciclos da cultura, os valores de PATDP foram cada vez mais se distanciando dos valores de PAPDP e PAPDT. Da cana-planta até a terceira soca os valores obtidos em função de touceiras doentes foram 0,$5 ; 2,0 ; 3,0$ e 8,0 vezes superiores àqueles obtidos em função de perfilhos doentes. Isto se justifica, em parte, pelo fato da variável PATDP levar em consideração as touceiras mortas pela doença, a partir do primeiro ciclo da cultura. Com perfilhos esta quantificação é impossivel. Por exemplo, no caso da variedade H50-7209, no último levantamento da terceira soca, a porcentagem acumulada de touceiras com carvão foi $91 \%$, enquanto que a porcentagem acumulada de perfilhos doentes por parcela foi $24 \%$ e por touceira $18 \%$.

O maior poder de distinção, aliado ao menor gasto com mão de obra e às melhores condições pós-inoculação permitem assegurar que a determinação da incidência do carvão em clones e variedades é melhor quando se quantifica a doença tomando como unidade amostral a touceira e não o perfilho. Contudo, isto só pode ser feito quando as touceiras são plantadas isoladamente, a partir de toletes com uma gema. 
A evolução das variáveis PAPDP e PAPDT foi bastante similar para todas as variedades nos quatro ciclos da cultura, confirmando observações feitas por Momol (1986).

Tabela 11 - Valores observados para as variáveis percentuais acumulativas: perfilhos doentes por parcela (PAPDP), perfilhos doentes por touceira (PAPDT), touceiras doentes por parcela (PATDP) e touceiras mortas por parcela (PATMP) nos quatro ciclos da cultura e variações observadas entre os ciclos.

\begin{tabular}{|c|c|c|c|c|c|c|c|c|}
\hline \multirow{2}{*}{$\begin{array}{l}\text { Ciclo da } \\
\text { cultura }\end{array}$} & \multicolumn{4}{|c|}{ Valor } & \multicolumn{4}{|c|}{$\begin{array}{l}\text { Variação em relação } \\
\text { ao ciclo anterior }\end{array}$} \\
\hline & PAPDP & PAPDT & PATDP & PATMP & PAPDP & PAPDT & PATDP & PATMP \\
\hline Cana-planta & 10,918 & 11,431 & 15,470 & 0,270 & - & - & - & - \\
\hline $1^{a}$ soca & 6,803 & 7,594 & 14,965 & 4,973 & $-37,690$ & $-33,567$ & $-3,264$ & 1741,852 \\
\hline $2^{\mathrm{a}}$ soca & 8,452 & 7,407 & 25,770 & 18,936 & 24,239 & $-2,462$ & 72,202 & 280,776 \\
\hline $3^{a}$ soca & 3,712 & 3,705 & 29,475 & 26,186 & $-56,081$ & $-49,980$ & 14,377 & 38,287 \\
\hline
\end{tabular}

Tabela 12 - Classificação das seis variáveis que apresentaram os menores valores para PTRAT(\%) e CV(\%) nos quatro ciclos da cultura.

\begin{tabular}{lllllll}
\hline Ciclo da & \multicolumn{5}{c}{ Classificação das variáveis } \\
\cline { 2 - 7 } cultura & $\mathbf{1}^{\mathbf{a}}$ & $\mathbf{2}^{\mathbf{a}}$ & $\mathbf{3}^{\mathbf{a}}$ & $\mathbf{4}^{\mathbf{a}}$ & $\mathbf{5}^{\mathbf{a}}$ & $\mathbf{6}^{\mathbf{a}}$ \\
\hline Cana-planta & PATDP & PAPDT & PAPDP & PATMP & --- & -- \\
$1^{\mathbf{a}}$ soca & PNPDP & PAPDP & PNTDP & PNPDT & PAPDT & PATDP \\
$\mathbf{2}^{\mathbf{a}}$ soca & PATDP & PATMP & PNPDP & PNTDP & PAPDP & PAPDT \\
$3^{\mathbf{a}}$ soca & PATDP & PATMP & PNTDP & PNPDT & PNPDP & PAPDT \\
\hline
\end{tabular}

PTRAT(\%) - Probabilidade porcentual de erro ao admitir que existe pelo menos um contraste significativo entre as variáveis para as 18 variedades do experimento CV(\%) - coeficiente de variaçāo (\%) 
Tabela 13 - Comparação dos valores de PTRAT(\%) e CV(\%) obtidos para a variável de porcentagem acumulada de touceiras doentes por parcela (PATDP) durante os quatro ciclos da cultura. Os valores representam médias de um ou mais ciclos.

\begin{tabular}{lrrrr}
\hline $\begin{array}{l}\text { Ciclo da } \\
\text { cultura }\end{array}$ & Média & CV(\%) & FTRAT $^{\mathbf{2}}$ & PTRAT(\%) \\
\hline P+S1+S2+S3 & 21,420 & 27,046 & 60,490 & 0,301 \\
S1+S2+S3 & 23,404 & 27,927 & 60,068 & 0,304 \\
P+S1+S2 & 18,735 & 28,061 & 57,293 & 0,326 \\
S2+S3 & 27,623 & 28,541 & 56,478 & 0,333 \\
S3 & 29,475 & 28,877 & 53,996 & 0,356 \\
S2 & 25,770 & 30,165 & 52,450 & 0,372 \\
P+S1 & 15,218 & 32,078 & 44,069 & 0,481 \\
S1 & 14,965 & 34,496 & 43,855 & 0,485 \\
P & 15,470 & 38,635 & 30,011 & 0,847 \\
\hline
\end{tabular}

1 - CV $(\%)=$ coeficiente de variação $(\%)$

2 - FTRAT = Distribuição $F$ de Snedecor

3 - PTRAT(\%) = Probabilidade porcentual de erro ao admitir que existe pelo menos um contraste

significativo entre as variáveis para as 18 variedades do experimento

$\mathbf{P}=$ cana-planta

S1 $=$ primeira soca

s2 = segunda soca

s3 $=$ terceira soca.

\subsubsection{Avaliação de dano}

Nos dois primeiros ciclos da cultura, os valores de AUDPC para as três variáveis cumulativas (touceiras doentes por parcela (PATDP), perfilhos doentes por parcela (PAPDP) e perfilhos doentes por touceira (PAPDT)) apresentaram alta correlação com o dano, apresentando valores de $R^{2}$ entre 0,91 e 0,98 . A partir da segunda soca, os valores de $R^{2}$ para PAPDP e PAPDT foram diminuindo, enquanto PATDP permaneceu estável.

Durante os quatro ciclos da cultura, PATDP foi a variável melhor correlacionada com o dano, apresentando coeficiente de determinação variando entre 0,97 e 0,99. Além disso, os coeficientes angulares das retas de regressão estiveram sempre ao redor de 0,9, indicando relação constante entre AUDPC da incidência e dano $(0,9 \%$ de dano para cada unidade de AUDPC de touceiras doentes) em todos os estádios de desenvolvimento da cultura. Para as demais 
variáveis, o coeficiente angular das retas de regressão foi variável entre os estádios de desenvolvimento da cultura e a própria relação incidência $x$ dano nem sempre foi linear.

A regressão linear conjunta dos dados de porcentagem de touceiras doentes e dano, obtidos nos quatro anos de avaliação, foi significativa $(p<0,001)$ e produziu a equação $y=0,905+0,86 x$ (onde $y=$ dano(\%) e $x=$ área sob a curva de progresso da incidência de carvão normalizada, medida em touceiras doentes) com coeficiente de determinação igual a 0,96. Segundo esta equação, o incremento de uma unidade de AUDPC provoca o incremento médio de 0,86\% de dano à cultura. Esta equação pode ser utilizada para identificar variedades tolerantes, que apresentariam relação incidência-dano sempre abaixo daquela reta de regressão.

Ao longo dos ciclos observou-se um aumento de ATD(\%), acompanhado por um aumento similar de Dano(\%) (Tabela 14). 
Tabela 14 - Valores da porcentagem acumulada de touceiras doentes (ATD(\%)) e da redução média de peso das touceiras devida ao carvão (Dano(\%)) nos quatro ciclos da cultura, para as 18 variedades testadas.

\begin{tabular}{|c|c|c|c|c|c|c|c|c|}
\hline \multirow[b]{2}{*}{ Variedade } & \multicolumn{4}{|c|}{$\operatorname{ATD}(\%)^{1}$} & \multicolumn{4}{|c|}{ Dano(\%) } \\
\hline & Cana-planta & $1^{\text {a } ~ s o c a ~}$ & $2^{a}$ soca & $3^{a}$ soca & Cana-planta & $1^{a}$ soca & $2^{\mathrm{a}}$ soca & $3^{a}$ soca \\
\hline B52107 & 12,590 & 7,460 & 8,620 & 10,260 & 8,305 & 5,698 & 4,919 & 8,985 \\
\hline CB40-35 & 22,920 & 16,910 & 21,430 & 27,500 & 16,311 & 15,557 & 19,282 & 26,542 \\
\hline Co421 & 11,890 & 12,770 & 16,510 & 12,770 & 10,899 & 11,208 & 12,837 & 12,169 \\
\hline Co462 & 8,330 & 10,420 & 15,380 & 18,450 & 6,722 & 8,444 & 10,967 & 15,081 \\
\hline $\begin{array}{l}\text { Co6806 } \\
\text { CP23-58 }\end{array}$ & $\begin{array}{l}1,400 \\
0,690\end{array}$ & $\begin{array}{l}2,100 \\
0,000\end{array}$ & $\begin{array}{l}6,500 \\
0,000\end{array}$ & $\begin{array}{l}4,350 \\
1820\end{array}$ & $\begin{array}{l}0,720 \\
0,690\end{array}$ & 828 & 5,984 & $\begin{array}{l}4,350 \\
1820\end{array}$ \\
\hline CP29-116 & 4,900 & 9,860 & 21,280 & 22,390 & 4,007 & 7,537 & 16,111 & 17,873 \\
\hline F13 & 12,500 & 9,770 & 17,860 & 25,000 & 9,656 & 9,413 & 17,860 & 25,000 \\
\hline H5O- & 33,330 & 72,140 & 87,600 & 91,300 & 9,575 & 57,712 & 71,592 & 91,300 \\
\hline IAC66/6 & 44,440 & 51,300 & 69,000 & 72,220 & 37,481 & 38,310 & 46,415 & 61,095 \\
\hline$M 31 / 45$ & 0,690 & 0,000 & 0,710 & 0,900 & 0,211 & - & 0,363 & 0,772 \\
\hline NA56-79 & 38,890 & 54,200 & 78,070 & 88,570 & 30,521 & 34,793 & 56,453 & 65,487 \\
\hline NCo310 & 60,420 & 67,630 & 71,930 & 62,730 & 55,457 & 59,317 & 56,973 & 56,877 \\
\hline SP70-1143 & 4,900 & 6,290 & 4,260 & 5,710 & 2,746 & 5,869 & 4,260 & 5,710 \\
\hline SP71-1406 & 34,970 & 37,680 & 46,970 & 44,630 & 24,992 & 33,543 & 41,140 & 43,584 \\
\hline SP71-6163 & 16,670 & 18,180 & 18,570 & 20,660 & 13,839 & 15,309 & 17,675 & 20,557 \\
\hline SP71-8210 & 0,000 & 0,000 & 0,000 & 0,000 & -- & -- & - & -- \\
\hline SP79-1011 & 3,500 & 3,500 & 4,200 & 5,590 & 3,044 & 3,500 & 4,200 & 4,296 \\
\hline Média & 17,391 & 21,123 & 27,161 & 28,603 & 13,834 & 20,536 & 24,189 & 27,147 \\
\hline
\end{tabular}

1 - ATD $(\%)=$ porcentagem de plantas doentes

2 - Dano(\%) = redução de produção provocada pelo carvão 


\section{CONCLUSÕES}

Embora a reação ao carvão seja uma característica varietal, de maneira geral ocorreu uma redução no peso das touceiras de $0,86 \%$ para cada $1 \%$ de AUDPC para touceiras afetadas nos quatro ciclos da cultura.

A redução no número de perfilhos industrializáveis foi o maior efeito provocado pelo carvão nas plantas infectadas.

Devido à melhor separação das variedades em função de sua reação ao carvão, à melhor correlação com o dano provocado pelo patógeno e à diminuição na mão de obra empregada durante os levantamentos, a incidência de carvão em clones e variedades de cana-de-açúcar deve ser quantificada por avaliações de porcentagem de touceiras doentes. 


\section{REFERÊNCIAS BIBLIOGRÁFICAS}

ALEXANDER, K.C. Growth of foci of infections, secondary spread, and loss in yield in smut (Ustilago scitaminea Sydow) disease of sugarcane. Sugarcane Pathologists' Newsletter, Beltsville, n. 28, p. 3-6, 1982.

ALEXOPOULOS, C.J.; MIMS, C.W.; BLACKWELL, M. Introductory mycology. $4^{a}$ edição. New York: John Wiley \& Sons, 1996, 869p.

AMORIM, L. Avaliação de doenças. In: BERGAMIN FILHO, A.; KIMATI, H.; AMORIM, L. (Ed.) Manual de Fitopatologia. São Paulo: Ceres, 1995. v. 1, cap. 32 , p. 647-671.

AMORIM, L. Epidemiologia do carvão (Ustilago scitaminea, Syd.) da cana-deaçúcar: curvas anuais e poliéticas de progresso da doença. Piracicaba, 1990. 134p. Tese (Doutorado) - Escola Superior de Agricultura "Luiz de Queiroz", Universidade de São Paulo.

ANTOINE, R. Smut. In: MARTIN, J.P.; ABBOTT, E.V.; HUGHES, C.G. (Ed.) Sugar

- cane diseases of the world. Amsterdam: Elsevier, 1961. v. 1, cap. 15, p. 326-353.

BEDENDO, I.P. Carvões. In: BERGAMIN FILHO, A.; KIMATI, H.; AMORIM, L. (Ed.) Manual de Fitopatologia. São Paulo: Ceres, 1995. v. 1, cap. 49, p. 881-888.

BENDA, G.T.A. Breeding for disease resistance. In: COPERSUCAR INTERNATIONAL SUGARCANE BREEDING WORKSHOP. Piracicaba, 1987. Anais. São Paulo: Copersucar, 1987. p. 161-179. 
BERGAMIN FILHO, A. Avaliação de danos e perdas. In: BERGAMIN FILHO, A.; KIMATI, H.; AMORIM, L. (Ed.) Manual de Fitopatologia. São Paulo: Ceres, 1995. v. 1, cap. 33, p. 672-690.

BERGAMIN FILHO, A.; AMORIM, L.; CARDOSO, C.O.N.; SANGUINO, A.; IRVINE, J.; SILVA, W.M. da Carvão da cana-de-açúcar e sua epidemiologia. Boletim Técnico Copersucar. Edição especial, p. 1-23, nov. 1987.

BOCK, K.R. Studies on sugarcane smut (Ustilago scitaminea) in Kenya. Transactions British Mycological Society, v. 47, p. 403-407, 1964.

CADERNOS COPERSUCAR, SÉRIE MELHORAMENTO. Análise do levantamento da situação do carvão da cana-de-açúcar na variedade NA56-79. s.I., n.7. 1985. $4 p$.

CAMPBELL, C.L.; MADDEN, L.V. Introduction to Plant Disease Epidemiology. New York: John Wiley \& Sons, 1990. 532p.

CASAGRANDE, M.V.; SANGUINO, A. Perda de produtividade devido à doença do carvão (Ustilago scitaminea Sydow) da cana-de-açúcar. In: VI SEMINÁRIO DE TECNOLOGIA AGRONÔMICA, Piracicaba, 1994. Anais. São Paulo: Copersucar, 1994. p. 249-254.

CHIARAPPA, L. Crop loss assessment methods. FAO Manual on Evaluation and Prevention of Losses by Pests, Diseases and Weeds. Farnham Royal, Commonwealth Agricultural Bureaux, 1971.

COMISSÃO DE CONTROLE DO CARVÃO DA CANA-DE-AÇÚCAR DO ESTADO DE SÃO PAULO. Campanha Integrada de Controle do Carvão em Canade-açúcar. São Paulo, 1985. 40p.

COMSTOCK, J.C.; FERREIRA, S.A.; TEW, T.L. Hawaii's approach to control of sugarcane smut. Plant Disease, v. 67, p. 452-457, 1983.

COMSTOCK, J.C.; HEINZ, D.J. A new race of culmicolous smut of sugarcane in Hawaii. Sugarcane Pathologists' Newsletter, Beltsville, n. 19, p. 24-25, 1977. 
COPERSUCAR. Avaliação de diferentes métodos de inoculação do carvão da cana-de-açúcar (Ustilago scitaminea Sydow). In: RELATÓRIO ANUAL 1994/95. Centro de Tecnologia Copersucar, Piracicaba, 1995. p. 19.

EL CAÑERO. Boletin tecnico de la division experimental duquesa. Consejo estatal del azucar, v. 10, n. 2, mar./abr. 1981. 30p.

EL-KHOLI, M.M. Methods for sugarcane smut control in Egypt. In: WILSON, J. R.; HOGARTH, D.M.; CAMPBELL, J.A.; GARSIDE, A.L. (Ed.) Sugarcane: research towards efficient and sustainable production. Brisbane: CSIRO Division of tropical crops and pastures, 1996. cap. 3, p. 146-148.

FERREIRA, S.A.; COMSTOCK, J.C. Smut yield loss - another look. Annual Report. Hawaiian Sugar Planters Association Experimental Station. Hawaii. 1982. p. 34-35.

FERREIRA, S.A.; COMSTOCK, J.C. Smut. In: RICAUD, C.; EGAN, B.T.; GILLASPIE Jr., A.G.; HUGHES, C.G. (Ed.) Diseases of Sugarcane - Major Diseases. Amsterdam: Elsevier, 1989. cap. 14, p. 211-229.

FIGUEIREDO, P.; MATSUOKA, S.; SILVA, W.M. da; TOKESHI, H.; FIGUEIREDO JÚNIOR., E.R.; SILVEIRA, A.P. da; MELLO, S.S.; PARADELA FILHO, O. Testes de resistência de variedades de cana-de-açúcar a Ustilago scitaminea Syd. em condições de campo. Biológico, v. 46, n. 10, p. 225-233, out. 1980.

FRY, W.E. Integrated control of potato late blight - Effects of polygenic resistance and techniques of timing fungicide applications. Phytopathology, v. 67, p. 1650-1655. 1977.

GLAZ, B.; DEAN, J.L.; MILLER, J.D. Yield effects of various levels of sugarcane smut infection in Florida. American Society of Sugar Cane Technologists, v. 4, p. 50-53, Apr. 1985.

HANDOJO, H.; LEGOWO, L. Smut trials in Indonesia. Sugar Cane, n. 1, p. 10-12, 1984. 
HIRSCHHORN, E. Caracteres del ciclo evolutivo del carbon de la caña de azucar.

Revista de Investigaciones Agrícolas, v. 4, n. 3, p. 317-328, 1950.

HOY, J.W. Incidence of sugarcane smut in Louisiana and its effect on yield. Plant Disease, v. 70, n. 1, p. 59-60, Jan. 1986.

HOY, J.W.; GRISHAM, M.P.; BENDA, G.T.A. Effect of Louisiana growing conditions on the overwintering of smut-infected sugar cane. Sugar Cane, $\mathrm{n}$. 3, p. 11-16, 1987.

IAMSUPASIT, N.; PLIANSINCHAI, U.; LEABWAN, U.; PA-OBLEK, S.; LAIRUNGREONG, C. Selection for smut resistance in two sugarcane populations. In: WILSON, J.R.; HOGARTH, D.M.; CAMPBELL, J.A.; GARSIDE, A.L. (Ed.) Sugarcane: research towards efficient and sustainable production. Brisbane: CSIRO Division of tropical crops and pastures, 1996. cap. 3, p. 149-150.

IREY, M.S. Yield losses in sugarcane variety CL65-260 due to sugarcane smut in Florida. Journal of American Society of Sugar Cane Technologists. Florida, 1986. v. 6, p. 32-36.

JAMES, G.L. Culmicolous smut of sugarcane and effect of its control on yield. In: CONGRESS OF THE INTERNATIONAL SOCIETY OF SUGAR CANE TECHNOLOGISTS, 15., Durban, 1974. Proceedings. Durban: ISSCT, 1974. p. 290-299.

JAMES, G.L. Smut susceptibility testing of sugarcane varieties in Rhodesia. Proceedings of The South African Sugar Technologists' Association. Rhodesia, June 1969. p. 85-92,

JAMES, W.C. Crop loss assessment. In: Johnston, A. \& Booth, C. (Ed.) Plant Pathologist's Pocketbook. Kew, Commonwealt Mycological Institute, 1983. p. 130-143.

KIMATI, H.; BERGAMIN FILHO, A. Principios gerais de controle. In: BERGAMIN FILHO, A.; KIMATI, H.; AMORIM, L. (Ed.) Manual de Fitopatologia. São Paulo: Ceres, 1995. v. 1, cap. 34, p. 692-709. 
LADD, S.L.; HEINZ, D.J.; MEYER, H.K. Control of sugarcane (Saccharum sp.) smut disease (Ustilago scitaminea) through breeding and selection of resistant clones. In: INTERNATIONAL SOCIETY OF SUGAR CANE TECHNOLOGISTS, 1977, São Paulo, 1977. Proceedings XVI Congress. São Paulo, ISSCT, 1977. p. 36-44.

LEU, L.S.; TSENG, W.S. Culmicolous smut of sugarcane in Taiwan. Two pathogenic strains of Ustilago scitaminea Sydow. In: INTERNATIONAL SOCIETY OF SUGAR CANE TECHNOLOGISTS, 1974, Durban, 1974. Proceedings XV Congress. Durban, ISSCT, 1974. p. 275-279.

LEU, L.S.; WISMER, C.A.; DANIELS, J.; HUTCHINSON, P.B. Co-operating programs for screening sugarcane varieties for resistance to diseases 1 . The Taiwan program. Sugarcane Pathologists' Newsletter, Beltsville, n. 4, p. 36$37,1970$.

LO, C.C. Sugarcane breeding for different environments. In: COPERSUCAR INTERNATIONAL BREEDING SUGARCANE WORKSHOP. Piracicaba, 1987. Anais. São Paulo: Copersucar, 1987. p. 189-202.

MACHADO JUNIOR, G.R.; SILVA, W.M. da; IRVINE, J.E. Sugarcane breeding in Brazil: The Copersucar program. In: COPERSUCAR INTERNATIONAL BREEDING SUGARCANE WORKSHOP. Piracicaba, 1987. Anais. São Paulo: Copersucar, 1987. p. 217-232.

MATA, J.F. da. Preservação e determinação de viabilidade de clamidósporos de Ustilago scitaminea. Piracicaba, 1975. 66p. Tese (Mestrado) - Escola Superior de Agricultura "Luiz de Queiroz", Universidade de São Paulo.

MILLER, J.D. The effect of smut on the USDA sugarcane breeding program at Canal Point. In: AMERICAN SOCIETY OF SUGAR CANE TECHNOLOGY, 9., Flórida, 1979. Florida: ASSCT, 1979. Proceedings. p. 61-67.

MOMOL, M.T. Epidemiological studies of sugarcane smut. Florida, 1986. 72 p. Dissertation (Ph.D.) - University of Florida. 
PEIXOTO, T.C. Refinamento dos métodos de melhoramento da cana-deaçúcar. Piracicaba, ESALQ/Depto. de Genética. 1981. 31p.

ROBINSON, R.A. Plant pathosystems. Berlin: Springer-Verlag, 1976. 184p.

SANGUINO, A. Principais moléstias da cana-de-açúcar. In: PARANHOS, S.B.(Ed.) Cana-de-açúcar cultivo e utilização. Campinas: Fundação Cargill, 1987. v. 2, cap. 6 , p. 741-757.

SANGUINO, A.; RICCI JUNIOR, A.; VARGAS P.G.; TOLEDO, A.C.D. Efeito da incidência do carvão na produtividade da cana-de-açúcar. Boletim Técnico Copersucar. n. 28, p. 11-13. 1984.

SANTOS, A.A.; TEIXEIRA, L.M.S.; ARAÚJO, F.E.; FREIRE, J.M. Ocorrência do carvão (Ustilago scitaminea) da cana-de-açúcar no Estado do Ceará. Fitopatologia Brasileira, v. 11, p. 749-751, 1986.

SILVA, W.M. da; SANGUINO, A. Evaluating reaction of american cane varieties to Ustilago scitaminea in Brazil. Sugarcane Pathologistis' Newsletter, Beltsville, n. 21, p. 10-11, 1978.

SORDI, R.A.; CASAGRANDE, M.V.; COELHO, J.A. Resistência ao carvão em progênies SP, conforme seus genitores. Boletim Técnico Copersucar, $n$. 48, p. 32-37, $1988 a$.

SORDI, R.A.; MATSUOKA, S.; MASUDA, Y.; AGUILLERA, M.M.; ABRAMO FILHO, J. Principais doenças da cana-de-açúcar na região centro-sul do Brasil. Araras: IAA, Planalsucar, 1988b. 77p.

SRINIVASAN, K.V. Methods for testing the resistance of sugarcane to disease. 5. Sugarcane smut. Sugarcane Pathologists' Newsletter, v. 1, n. 2, p. 7, 1969.

TÓFFANO, W.B. O carvão na região de Assis. Contribuição da Refinadora Paulista S.A. para a campanha de combate ao carvão da cana-de-açúcar. Piracicaba, 1953. 25p. 
TOKESHI, H. Avaliação de perdas pelo carvão da cana-de-açúcar. Coleção Sopral, n. 15, dez. 1987. 26 p.

TOKESHI, H. Carvão da cana-de-açúcar. Etiologia e medidas de controle. Revista da Sociedade dos Técnicos Açucareiros e Alcooleiros do Brasil, v. 4, n. 1, set./out., 1985. Piracicaba: STAB, 1985. p. 26-34.

WALLER, J.M. Sugarcane smut (Ustilago scitaminea) in Kenia, I. Epidemiology. Transactions British Mycological Society, v. 52, p. 139-151, 1969.

WARAITCH, K.S. Performance of various clones of sugarcane for resistance to sugarcane smut (Ustilago scitaminea Sydow.). Sugarcane Pathologists' Newsletter, Beltsville, n. 2, p. 7-10, 1982.

WHETZEL, H.H.; HESLER,L.R.; GREGORY C.T.; RANKIN,W.H. Laboratory Outlines in Plant Pathology. Philadelphia: W.B. Saunders, 1925. 231p.

WHITTLE, A.M. General discussion on smut. In: FIRST INTER-AMERICAN SUGAR CANE SEMINAR. Florida, 1980. Proceedings. Florida, 1980. p. 33.

WHITTLE, A.M.; WALKER, D.I.T. Interpretation of sugarcane smut susceptibility trials. Tropical Pest Management, v. 28, n. 3, p. 228-237, 1982.

WU, K.K.; LADD, S.L.; HEIZ, D.J.; MEYER, H.K. Combining ability analysis in sugarcane smut resistance. Sugarcane Breeders Newsletter, n. 39, p. 5962, 1977.

ZADOKS, J.C. On the conceptual basis of crop loss assessment: the threshold theory. Annual Review Phytopathology, v. 23, p. 455-473, 1985. 
Anexo 1- Mapa de plantio do experimento no campo.

\begin{tabular}{|c|c|c|c|c|c|}
\hline SP70-1143 & CP29-116 & SP71-6163 & C0421 & Co6806 & $B 52107$ \\
\hline NA56-79 & Co462 & SP79-1011 & SP71-8210 & M31/45 & NCO310 \\
\hline H50-7209 & CB4035 & IAC66/6 & SP71-1406 & F134 & CP23588 \\
\hline
\end{tabular}

BLOCO 2

\begin{tabular}{|c|c|c|c|c|c|}
\hline H50-7209 & NA56-79 & SP71-1406 & SP71-8210 & Co6806 & Co462 \\
\hline SP79-1011 & F134 & CP29-116 & NC0310 & SP70-1143 & CP23588 \\
\hline CB40-35 & M31/45 & B52107 & SP71-61๘3 & IAC66/6 & Co421 \\
\hline
\end{tabular}

\begin{tabular}{|c|c|c|c|c|c|}
\hline CP23-588 & SP71-1406 & SP79-1011 & CP29-116 & CB40-35 & SP70-1143 \\
\hline Co6806 & H50-7209 & IAC66/6 & B52107 & SP71-61๘3 & C0462 \\
\hline SP71-8210 & NA56-79 & NCo310 & M31/45 & F134 & C0421 \\
\hline
\end{tabular}

\begin{tabular}{|c|c|c|c|c|c|}
\hline SP71-1406 & SP79-1011 & M31/45 & NCo310 & B52107 & Co6806 \\
\hline CP23588 & SP71-61๘3 & Co462 & F134 & CP29-116 & CB40-35 \\
\hline IAC66/6 & Co421 & SP71-8210 & H50-7209 & SP70-1143 & NA56-79 \\
\hline
\end{tabular}


Anexo 2 - Porcentagem acumulada de perfilhos doentes por parcela (PAPDP) para as 18 variedades do experimento, durante a cana-planta.

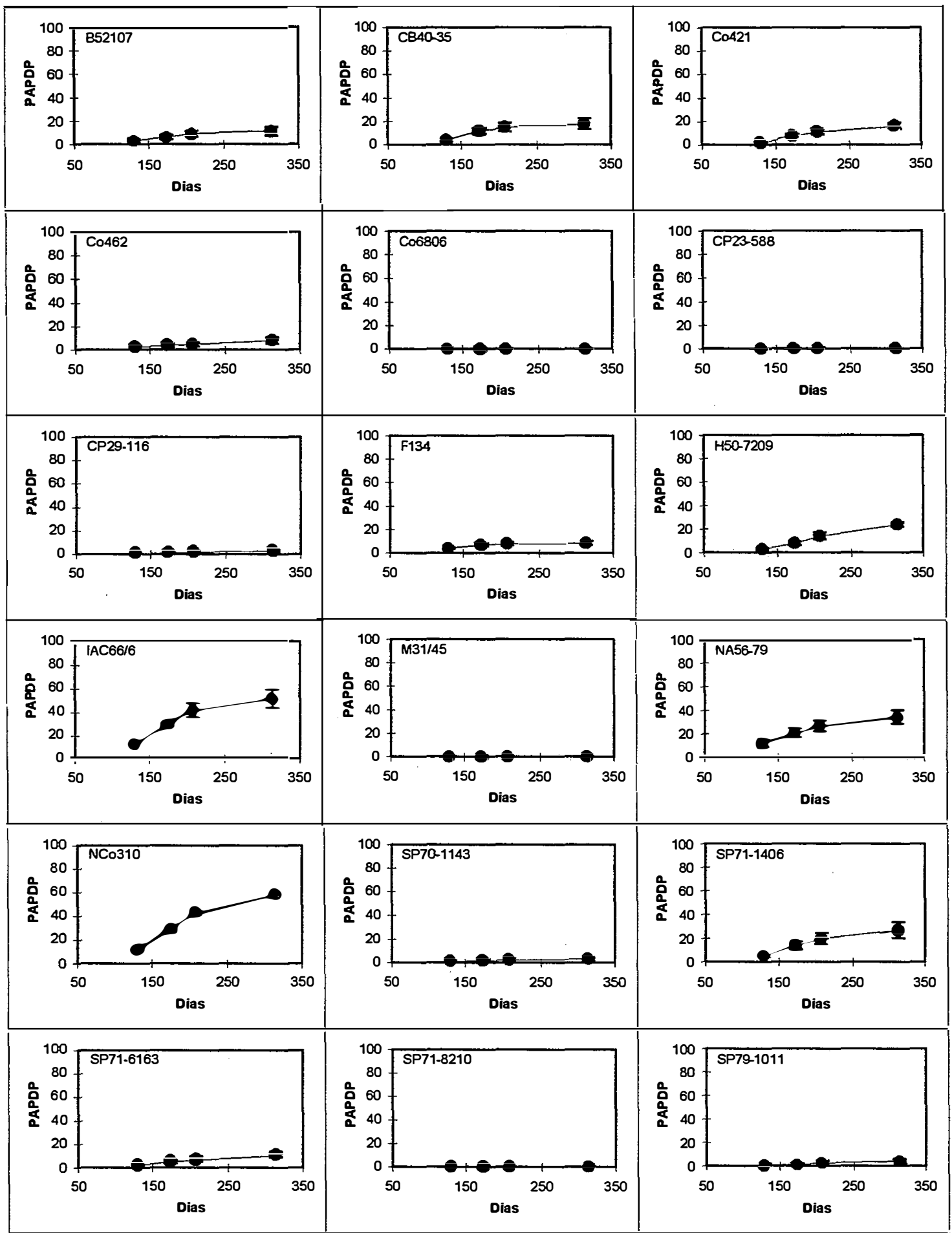


Anexo 3 - Porcentagem acumulada de perfilhos doentes por touceira (PAPDT) para as 18 variedades do experimento, durante a cana-planta.

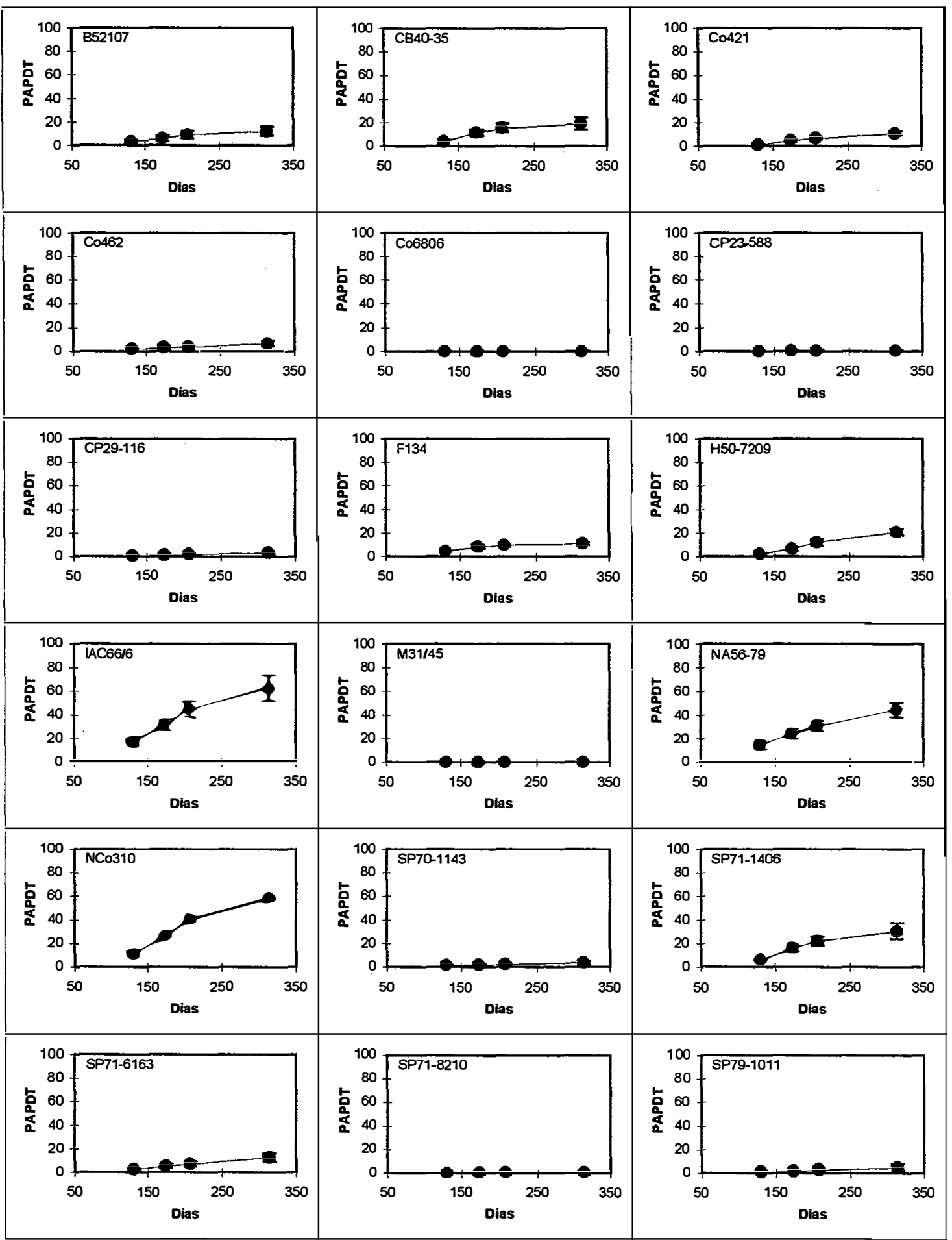


Anexo 4 - Porcentagem acumulada de touceiras doentes por parcela (PATDP) para as 18 variedades do experimento, durante a cana-planta.

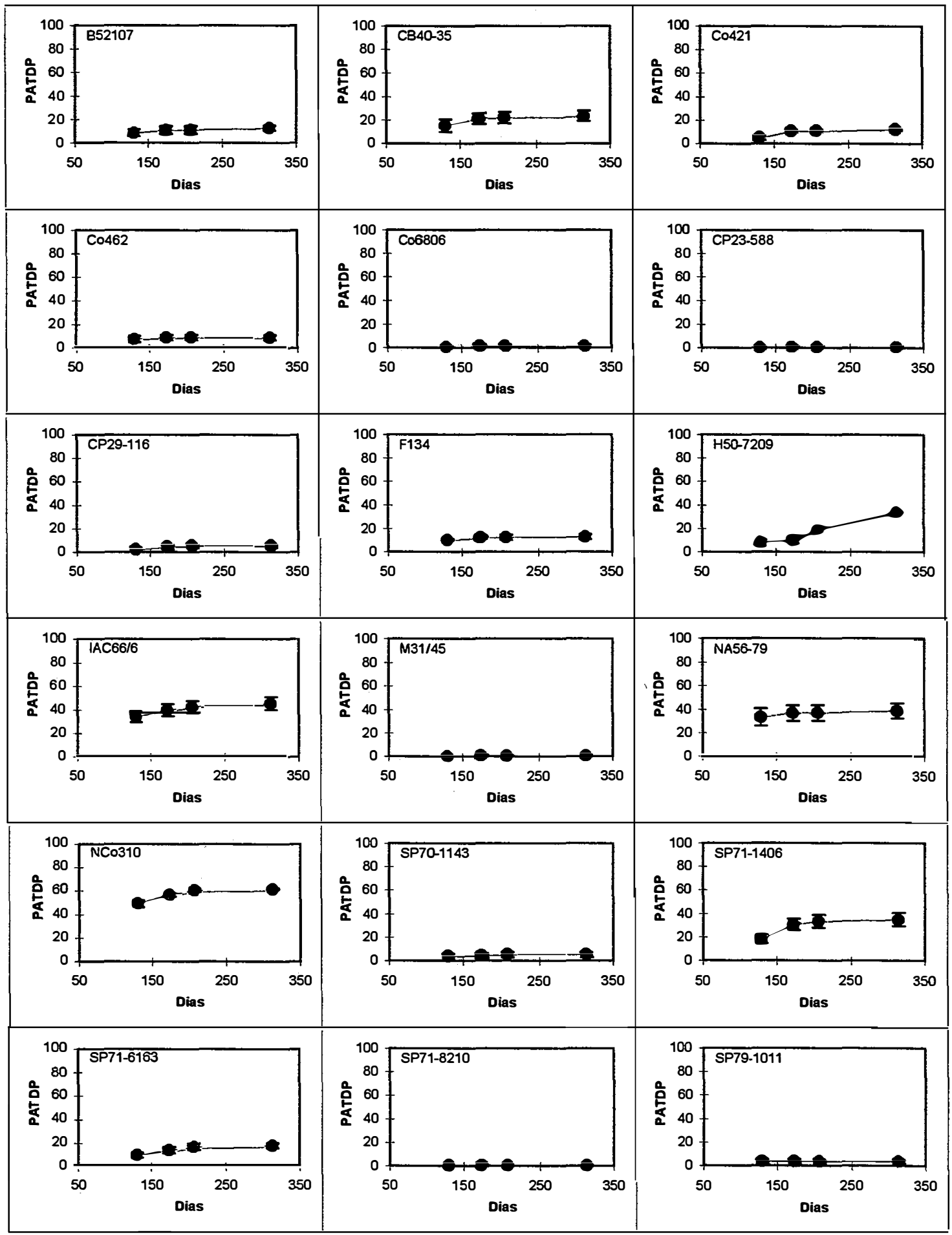


Anexo 5 - Porcentagem acumulada de touceiras mortas por parcela (PATMP) para as 18 variedades do experimento, durante a cana-planta.

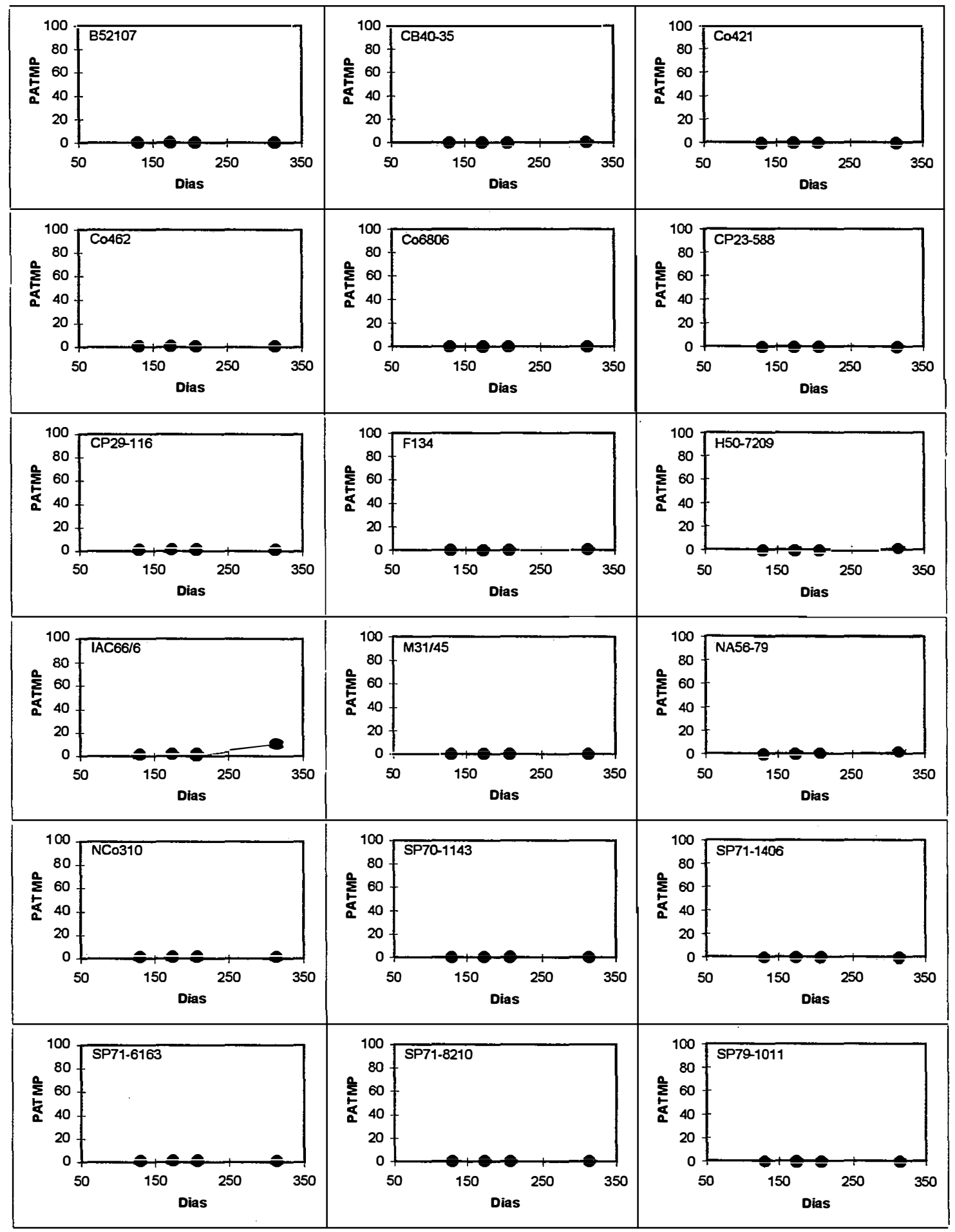


Anexo 6 - Porcentagem acumulada de perfilhos doentes por parcela (PAPDP) para as 18 variedades do experimento, durante a primeira soca.

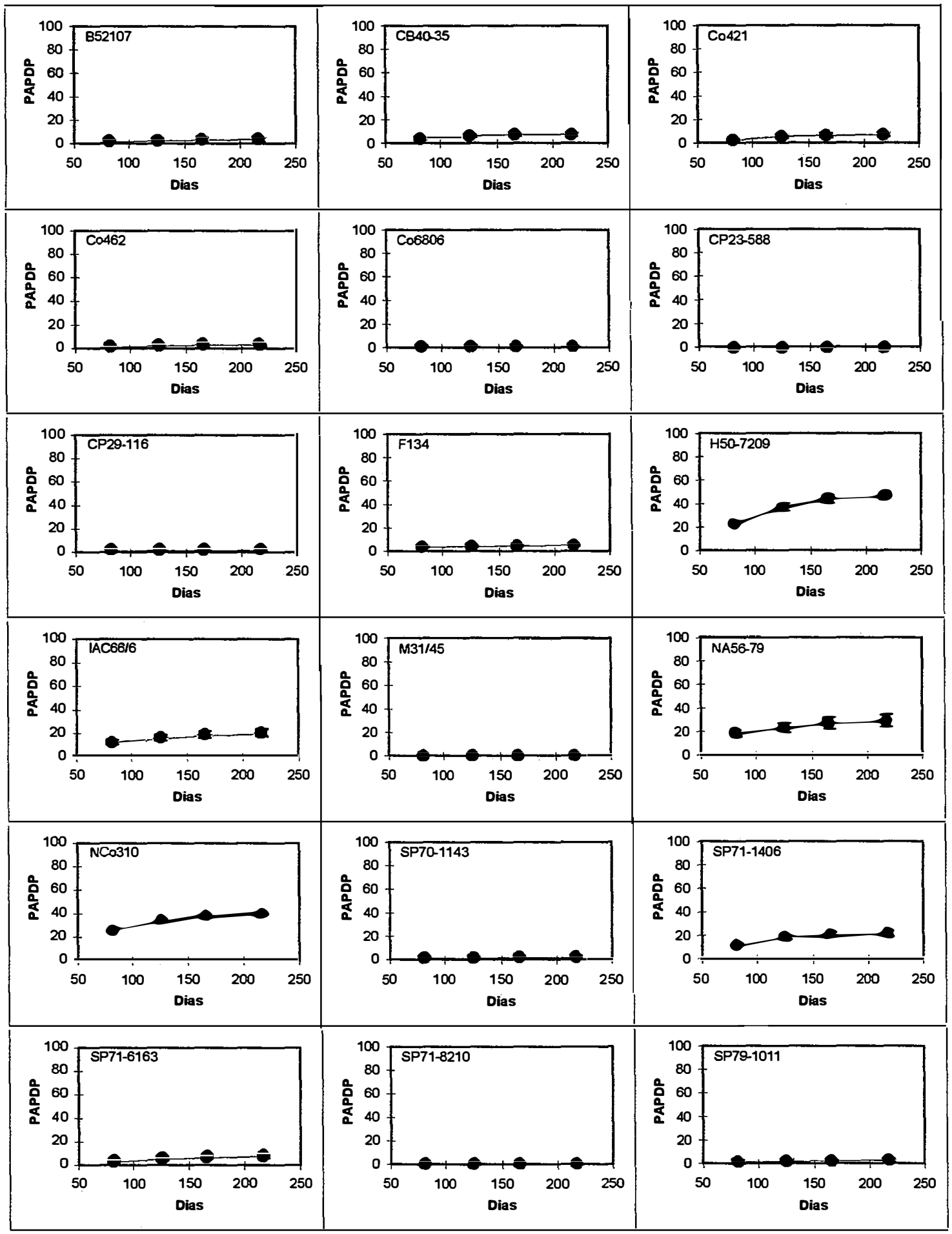


Anexo 7 - Porcentagem acumulada de perfilhos doentes por touceira (PAPDT) para as 18 variedades do experimento, durante a primeira soca.

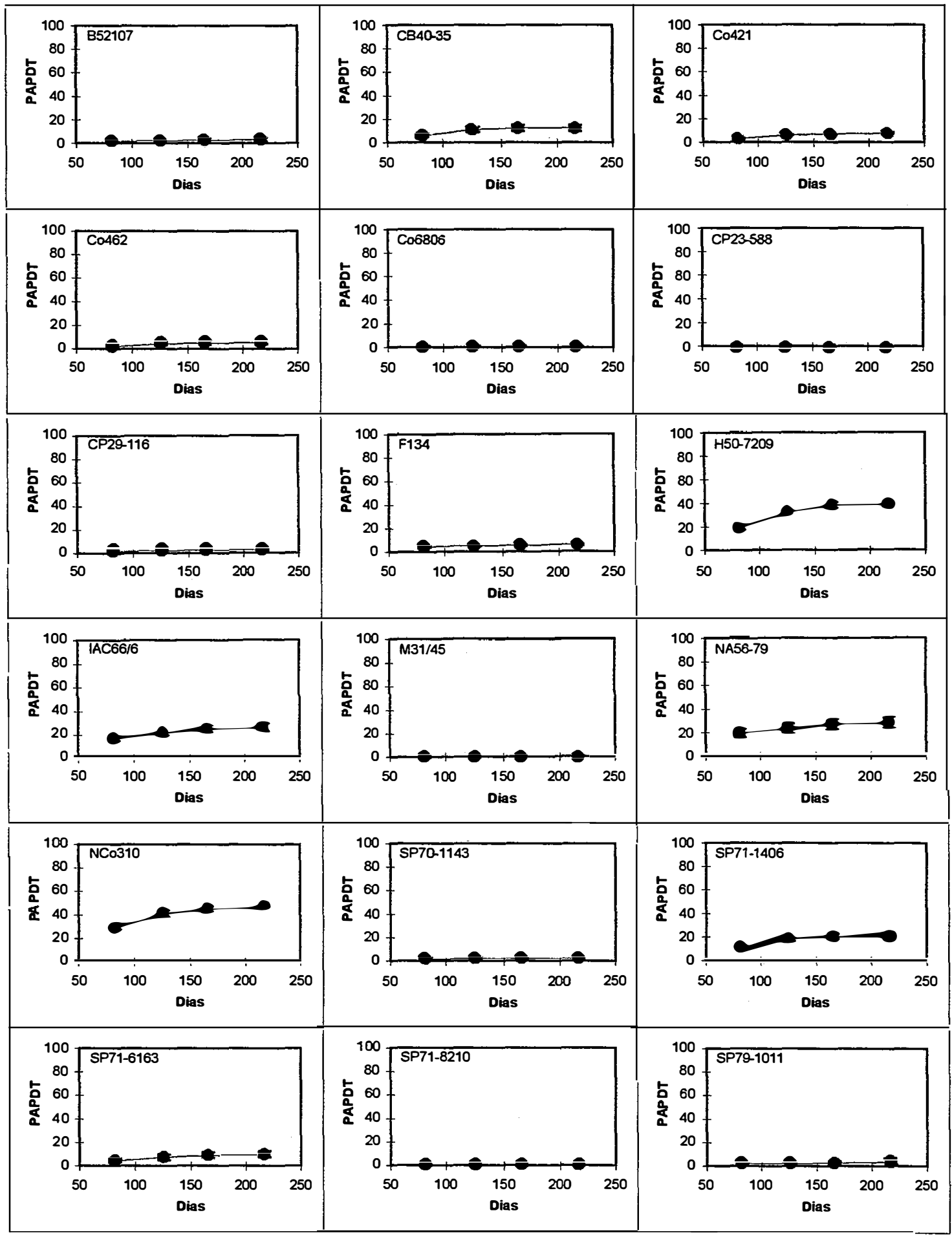


Anexo 8- Porcentagem acumulada de touceiras doentes por parcela (PATDP) para as 18 variedades do experimento, durante a primeira soca.

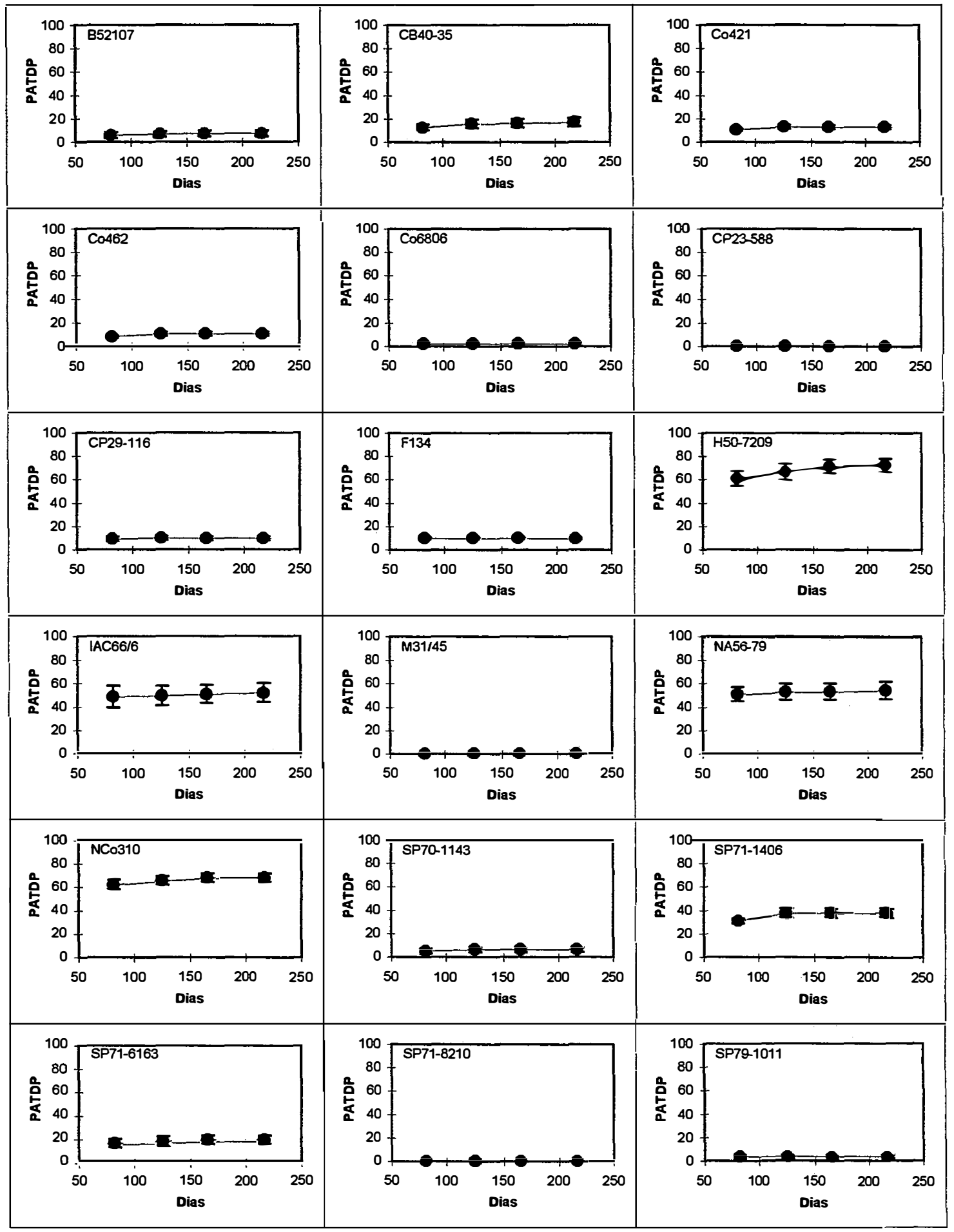


Anexo 9 - Porcentagem acumulada de touceiras mortas por parcela (PATMP) para as 18 variedades do experimento, durante a primeira soca.

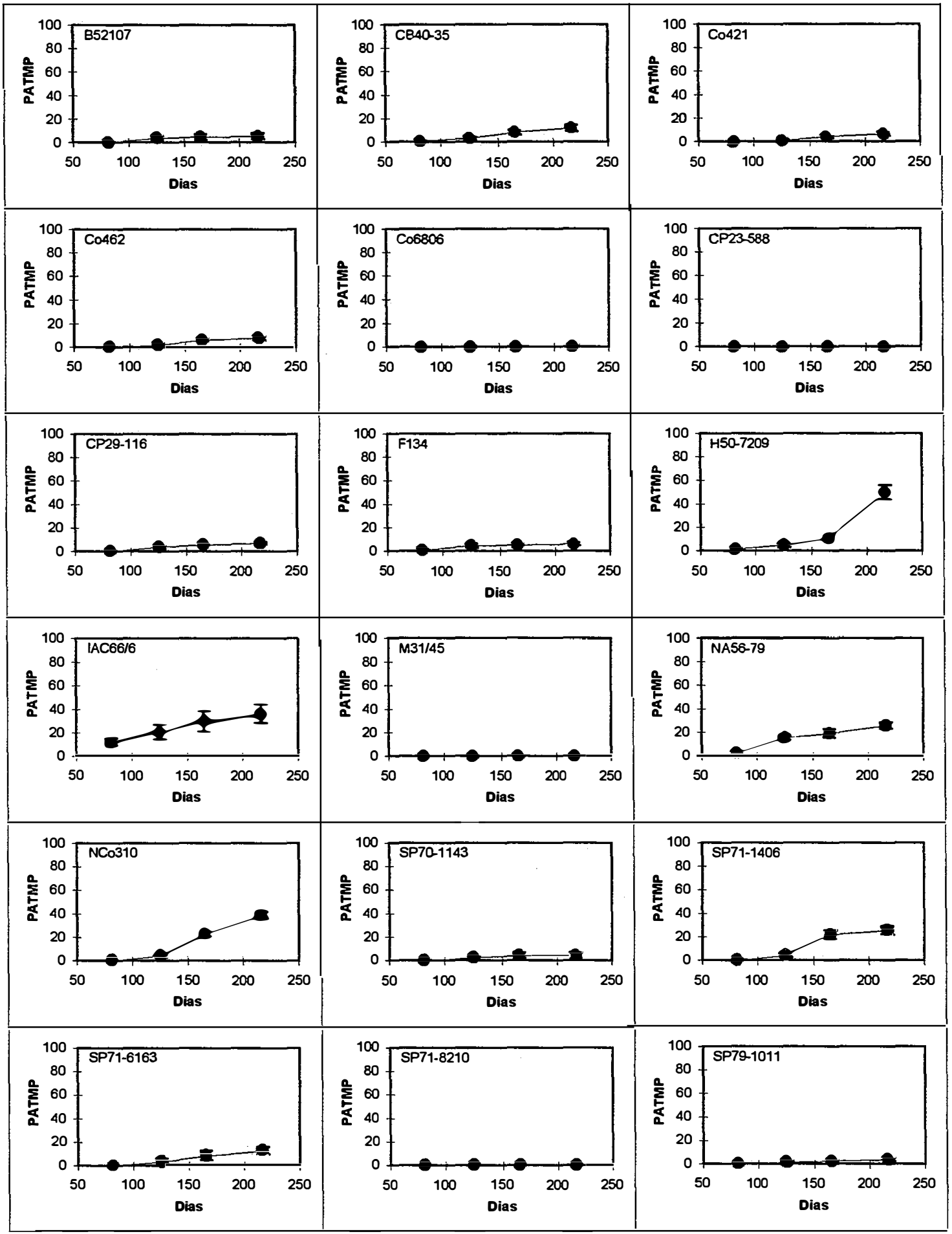


Anexo 10 - Porcentagem não acumulada de perfilhos doentes por parcela (PNPDP) para as 18 variedades do experimento, durante a primeira soca.

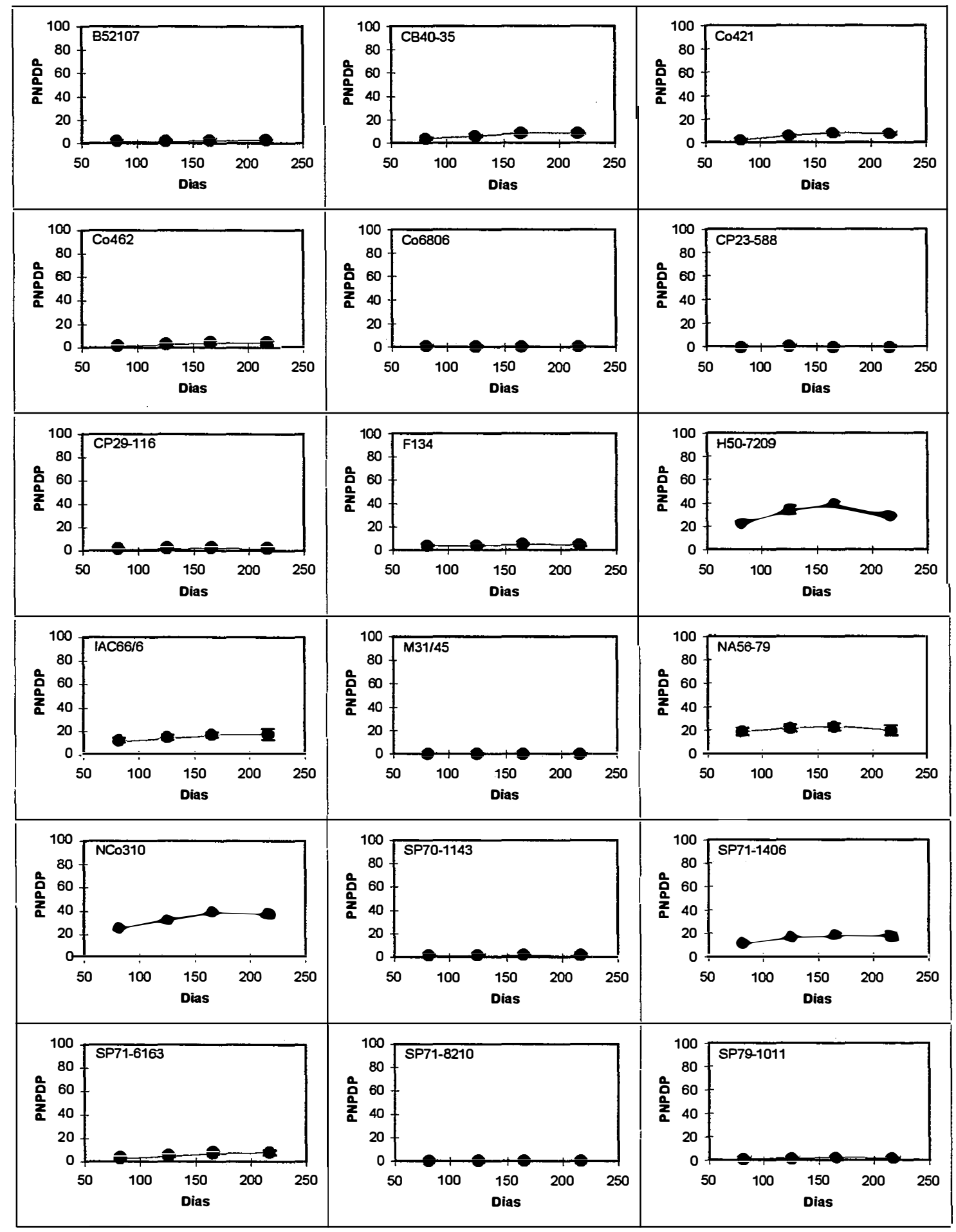


Anexo 11 - Porcentagem não acumulada de perfilhos doentes por touceira (PNPDT) para as 18 variedades do experimento, durante a primeira soca.

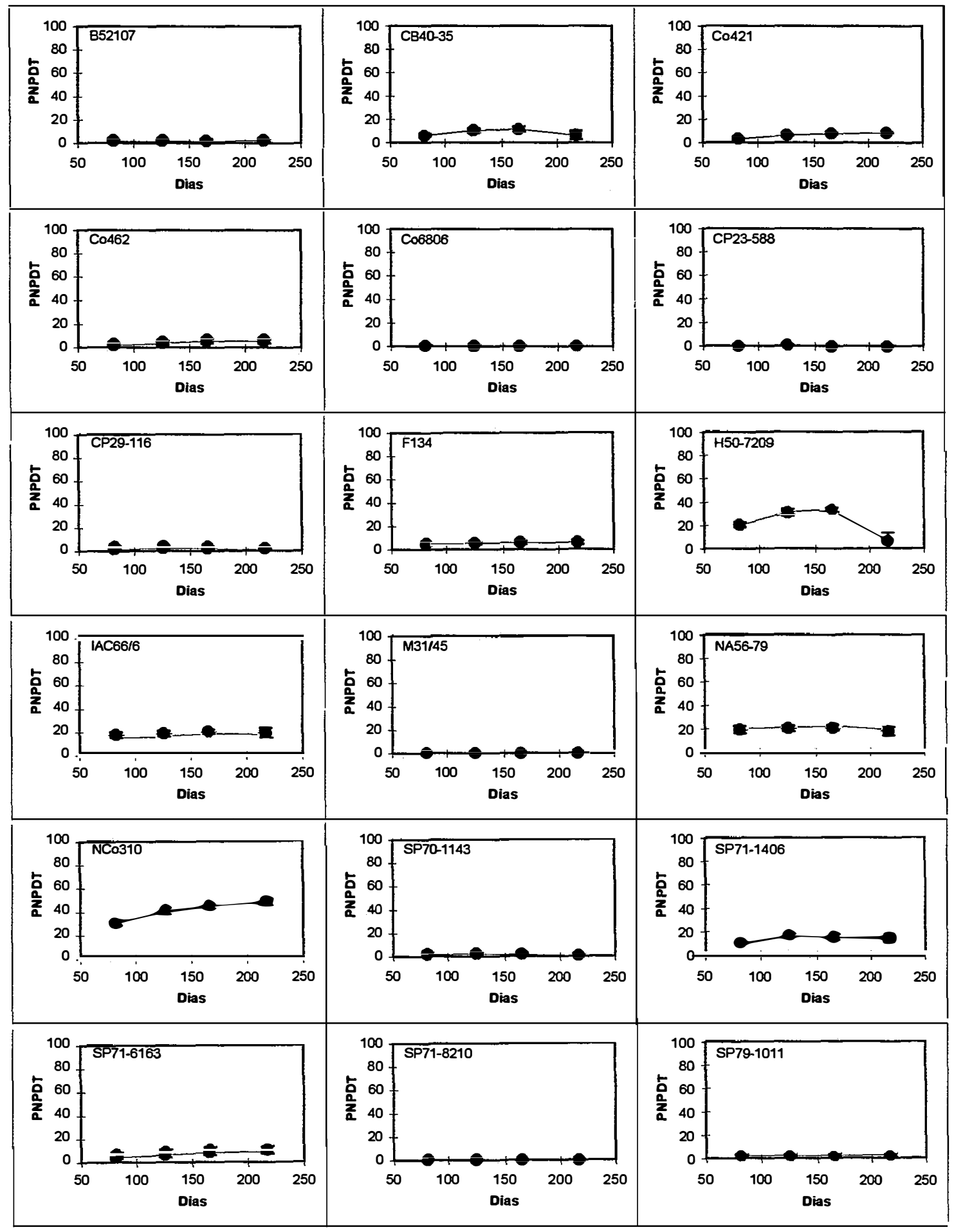


Anexo 12 - Porcentagem não acumulada de touceiras doentes por parcela (PNTDP) para as 18 variedades do experimento, durante a primeira soca.

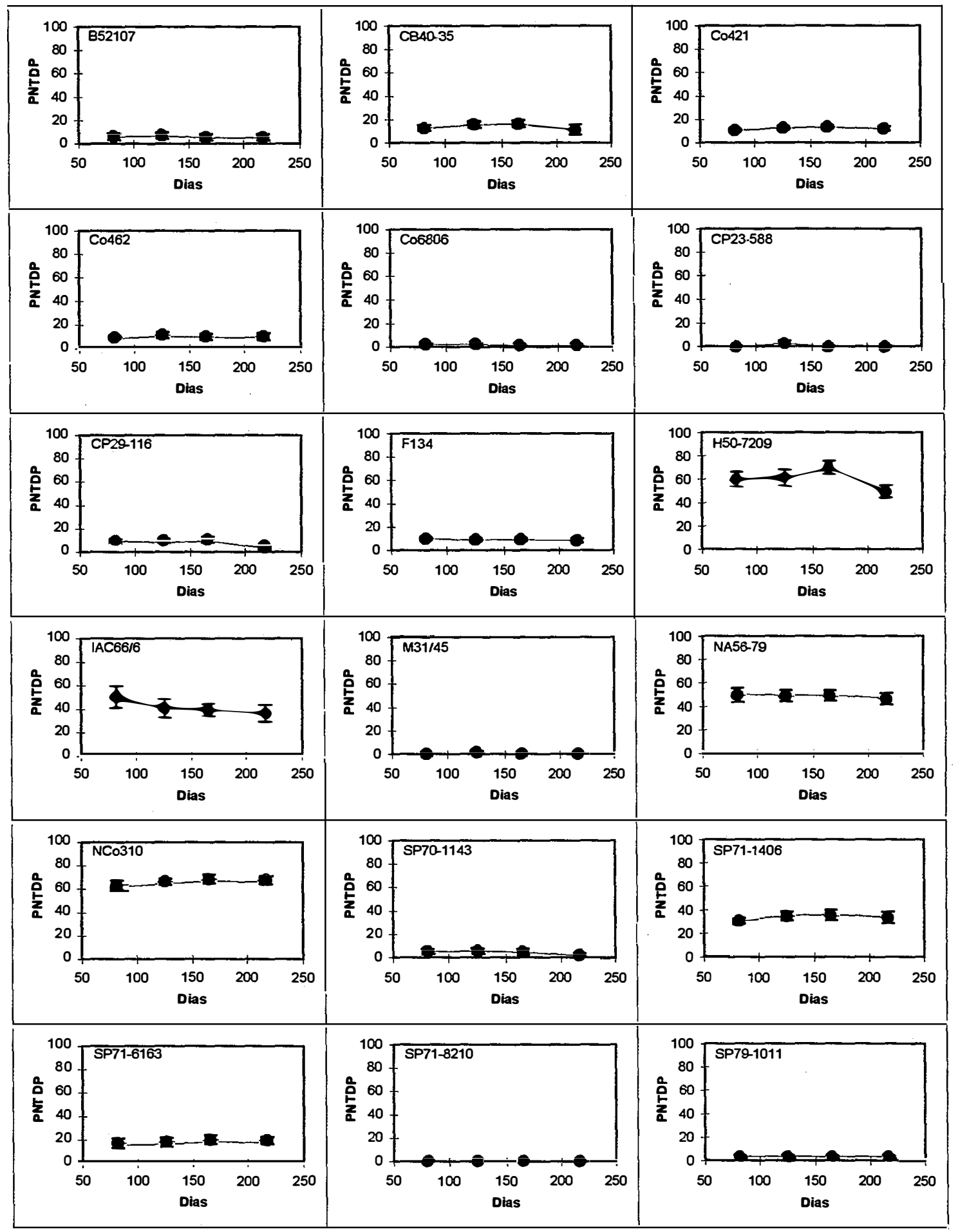


Anexo 13 - Porcentagem acumulada de perfilhos doentes por parcela (PAPDP) para as 18 variedades do experimento, durante a segunda soca.

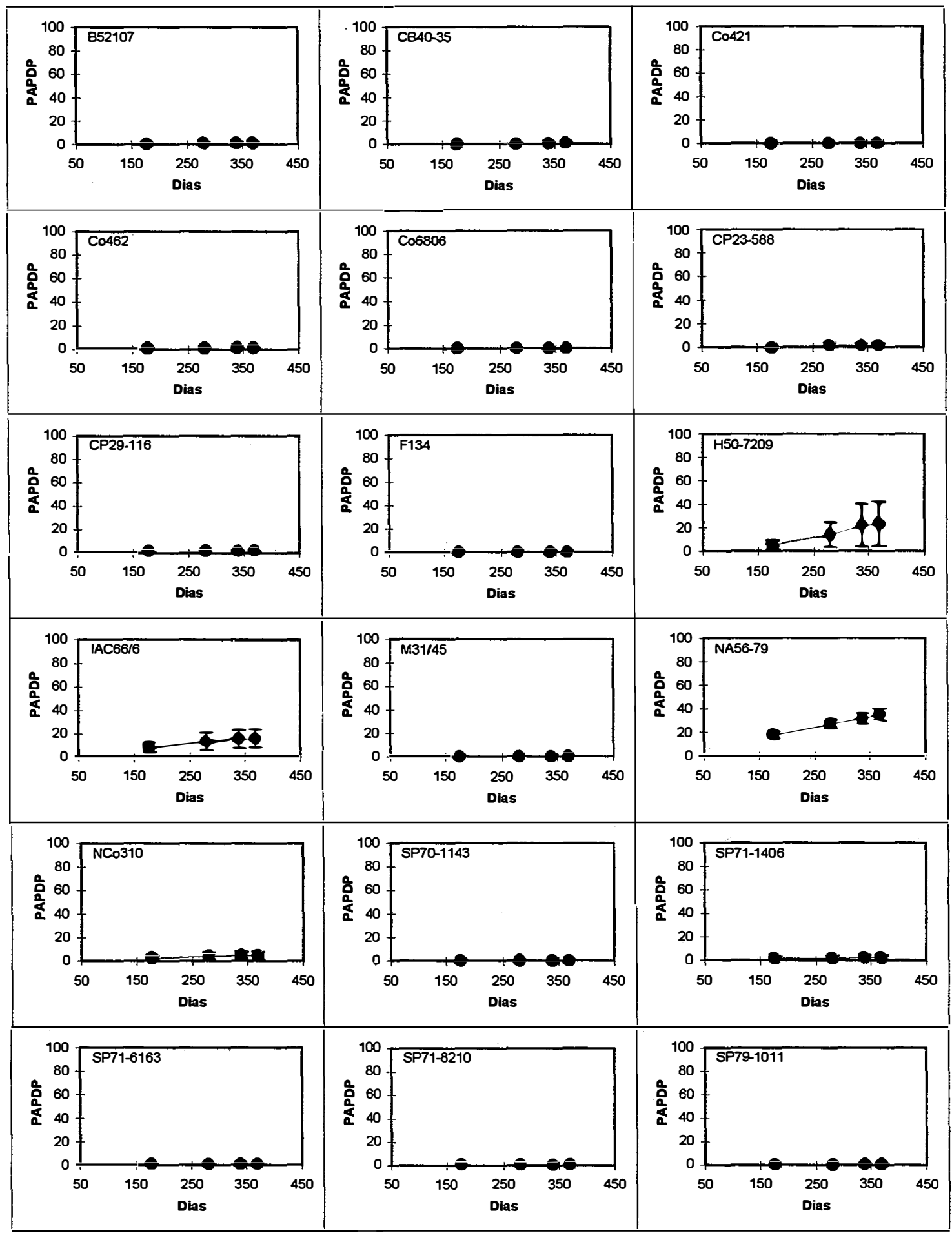


Anexo 14 - Porcentagem acumulada de perfilhos doentes por touceira (PAPDT) para as 18 variedades do experimento, durante a segunda soca.

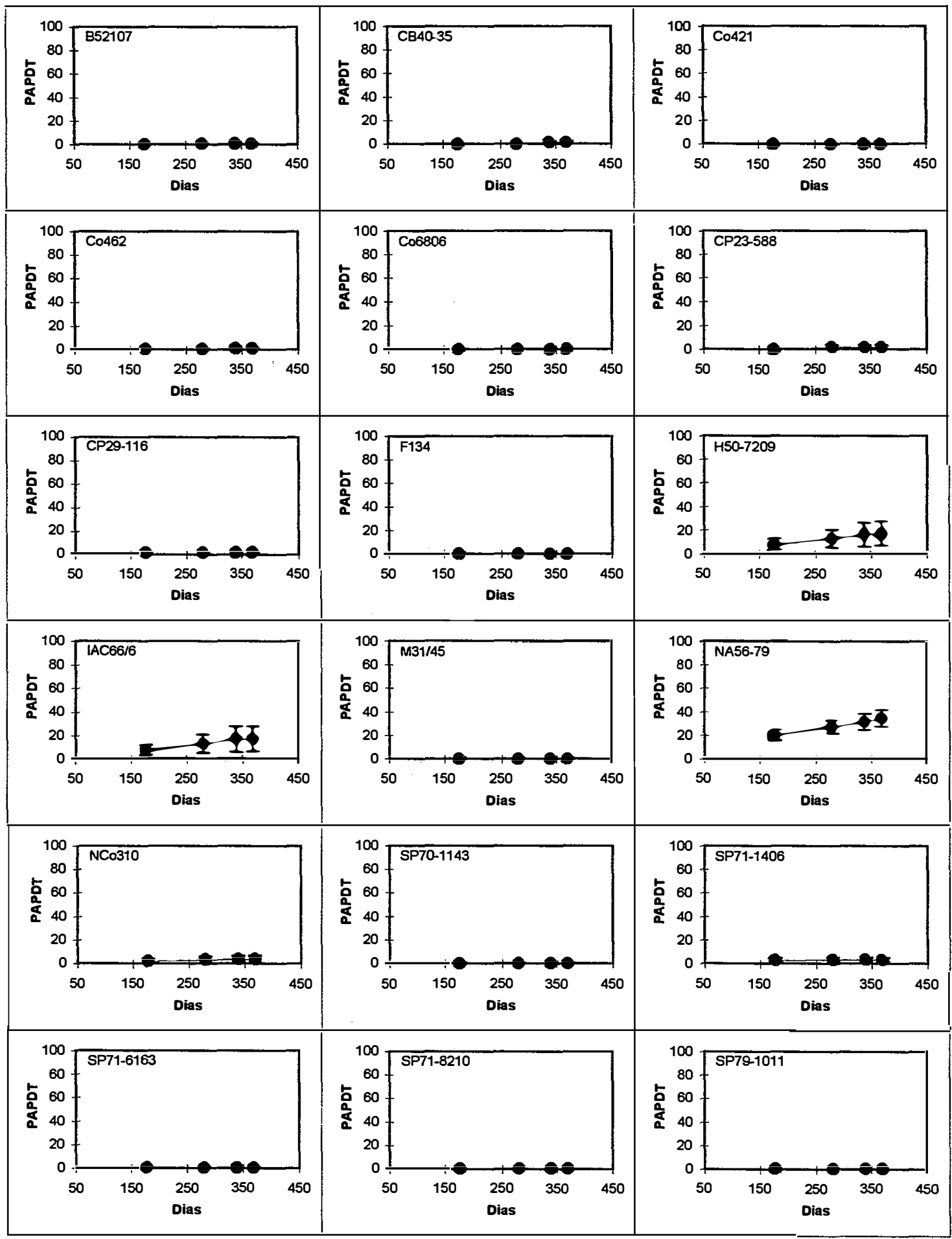


Anexo 15 - Porcentagem acumulada de touceiras doentes por parcela (PATDP) para as 18 variedades do experimento, durante a segunda soca.

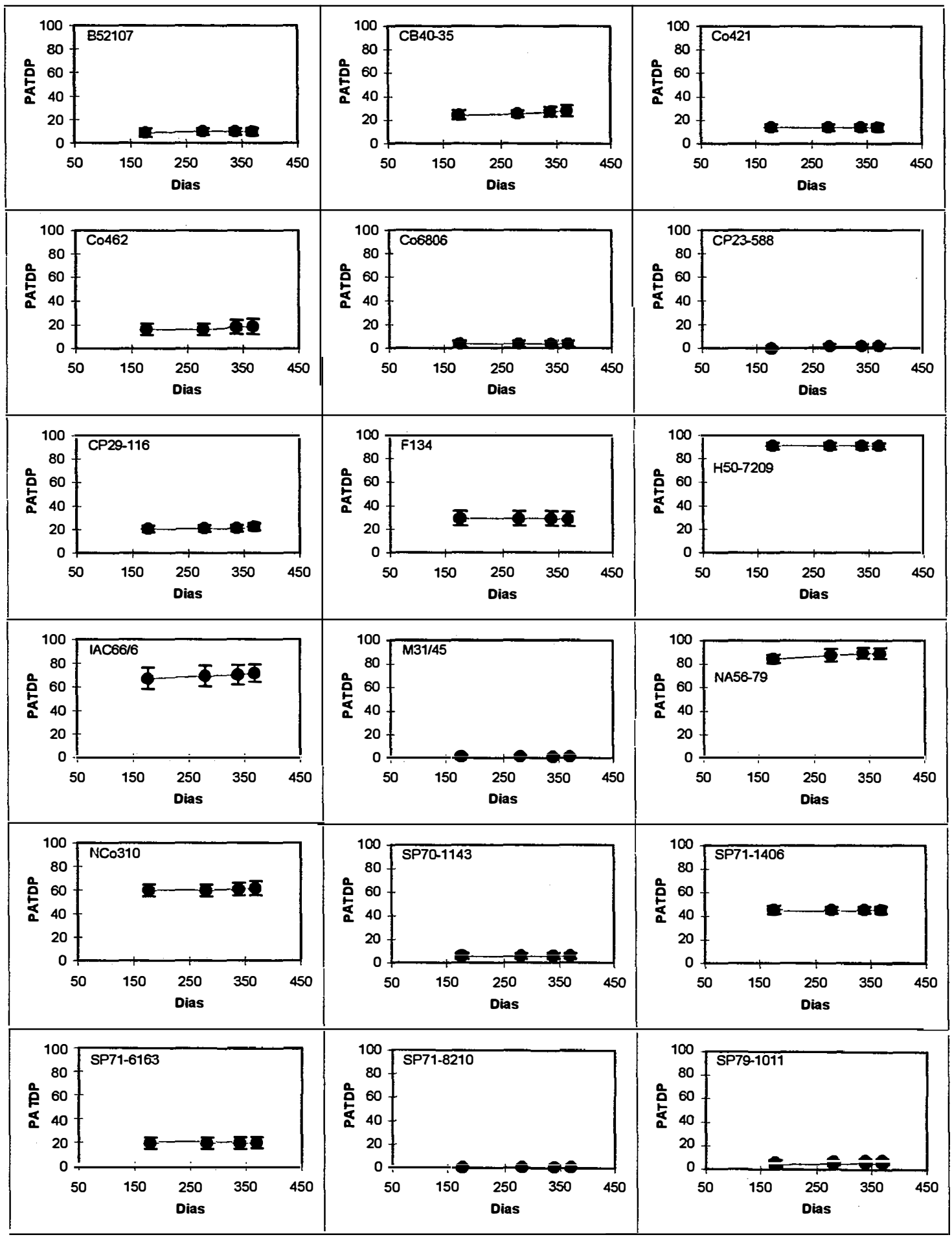


Anexo 16 - Porcentagem acumulada de touceiras mortas por parcela (PATMP) para as 18 variedades do experimento, durante a segunda soca.

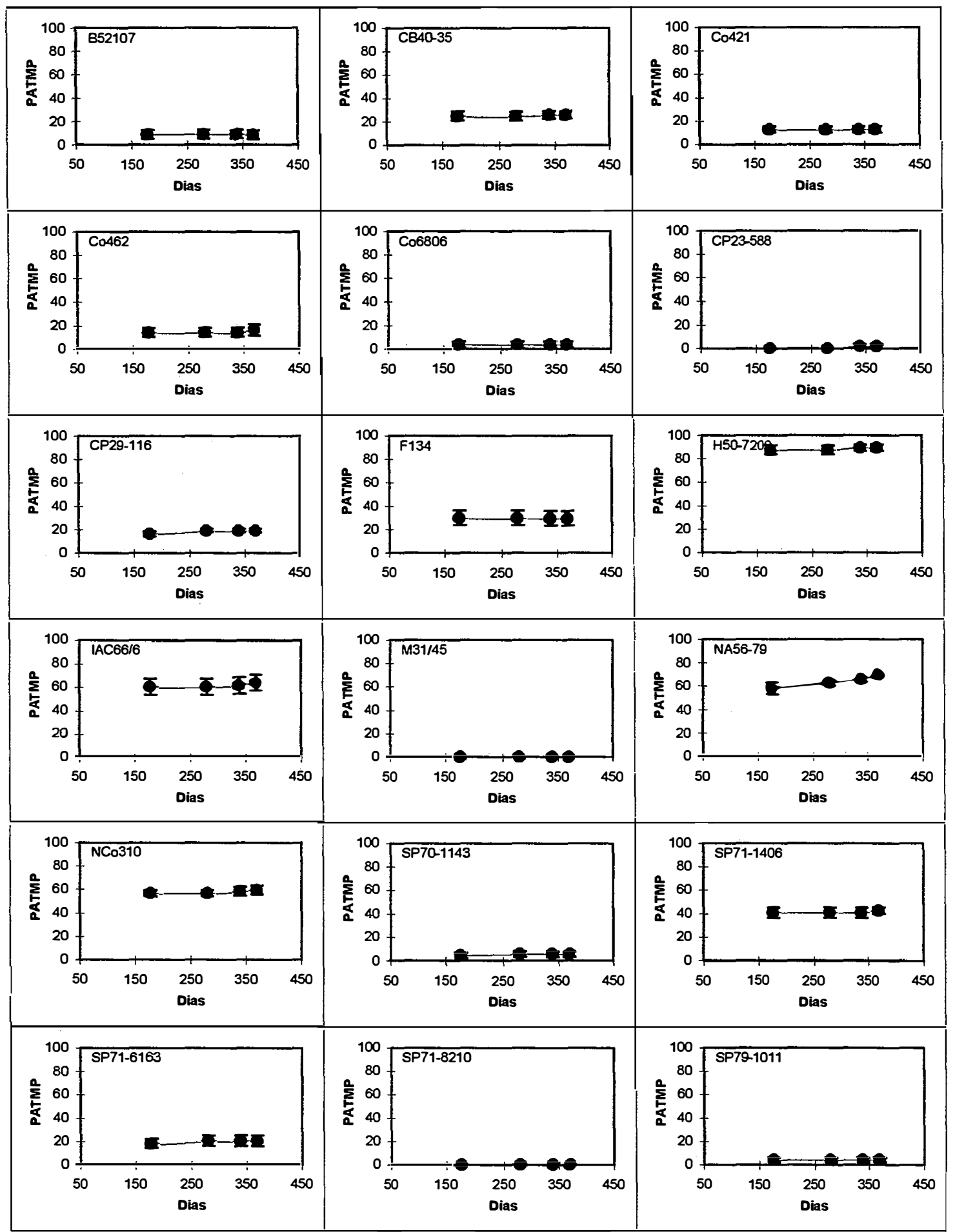


Anexo 17 - Porcentagem não acumulada de perfilhos doentes por parcela (PNPDP) para as 18 variedades do experimento, durante a segunda soca.

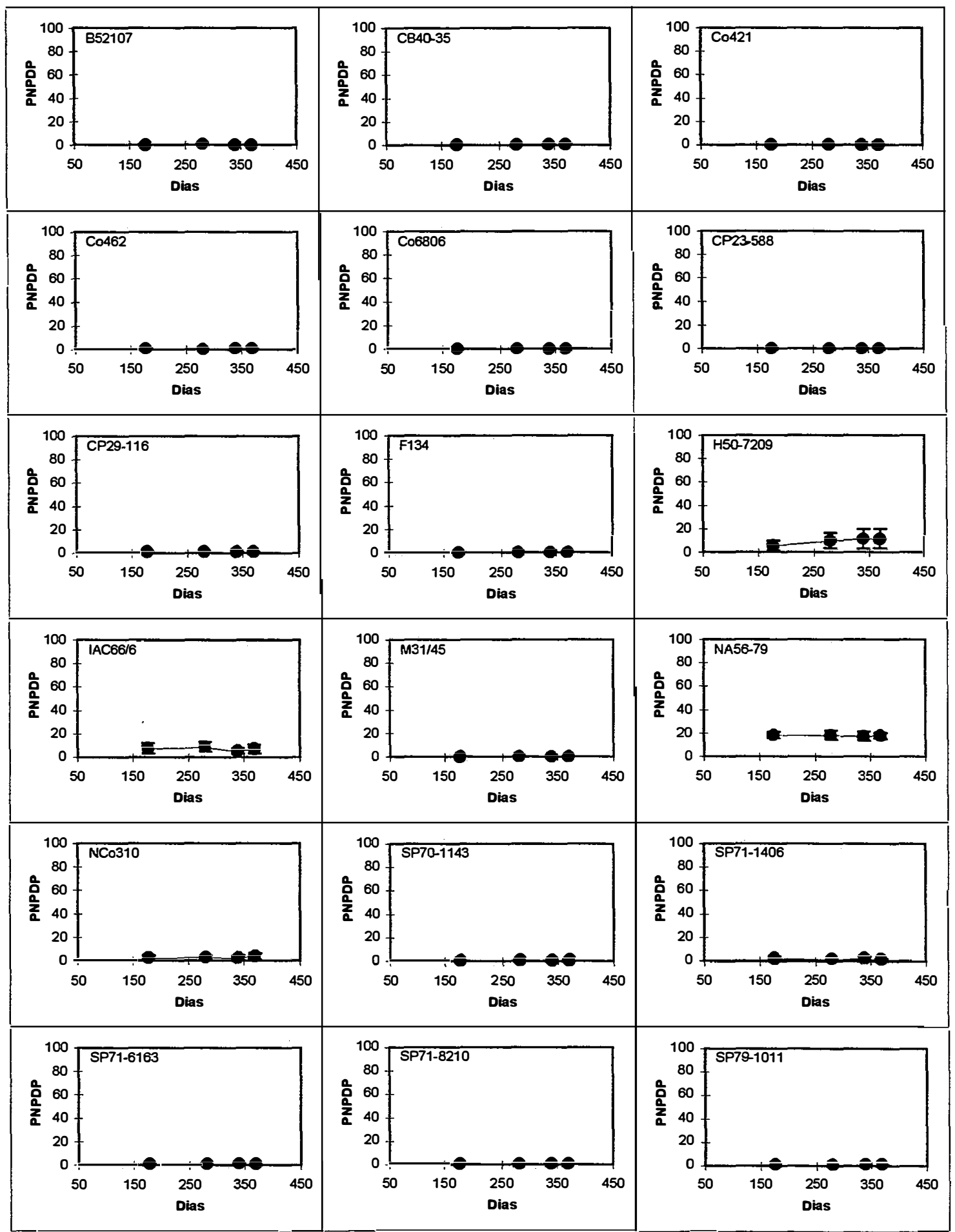


Anexo 18 - Porcentagem não acumulada de perfilhos doentes por touceira (PNPDT) para as 18 variedades do experimento, durante a segunda soca.

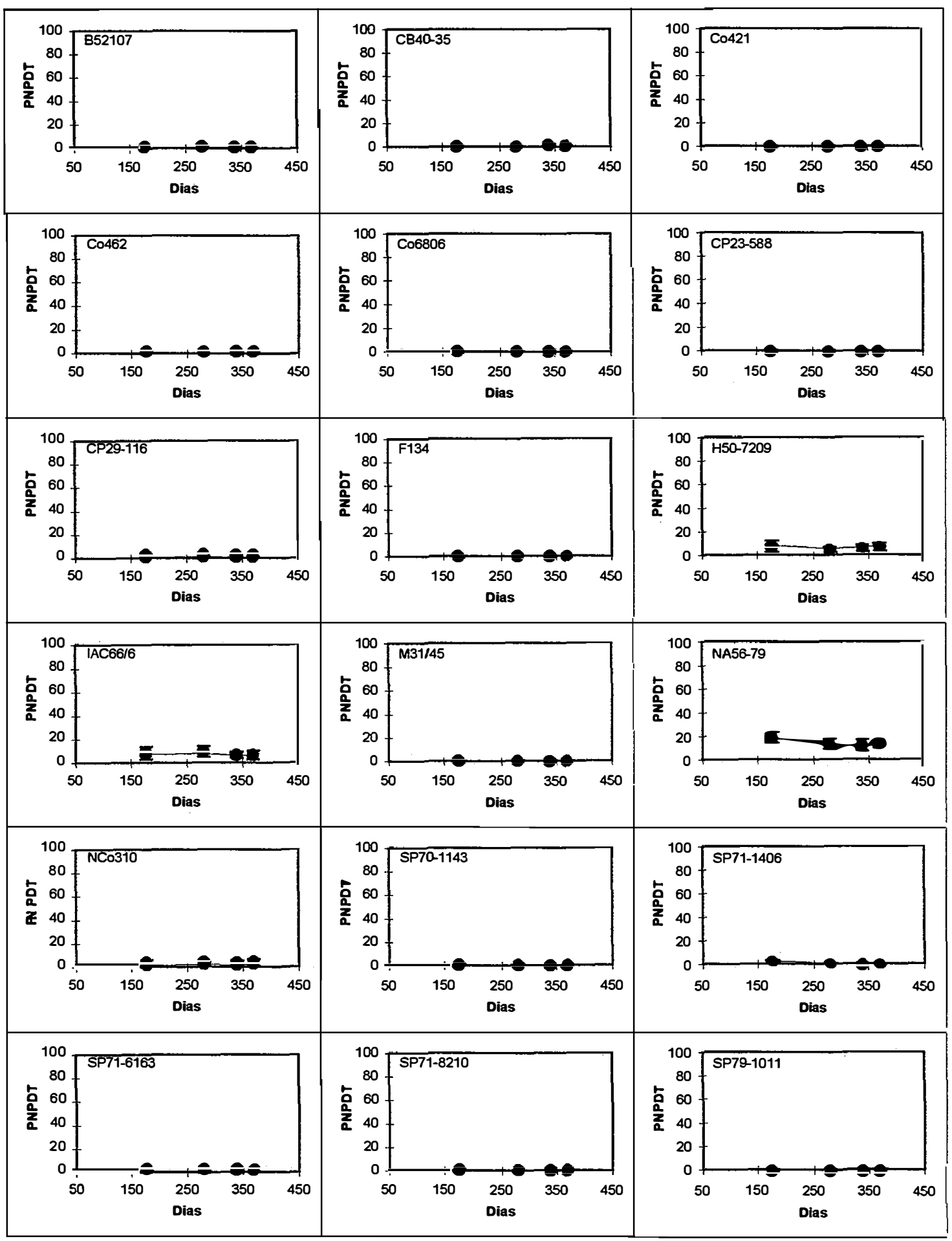


Anexo 19 - Porcentagem não acumulada de touceiras doentes por parcela (PNTDP) para as 18 variedades do experimento, durante a segunda soca.

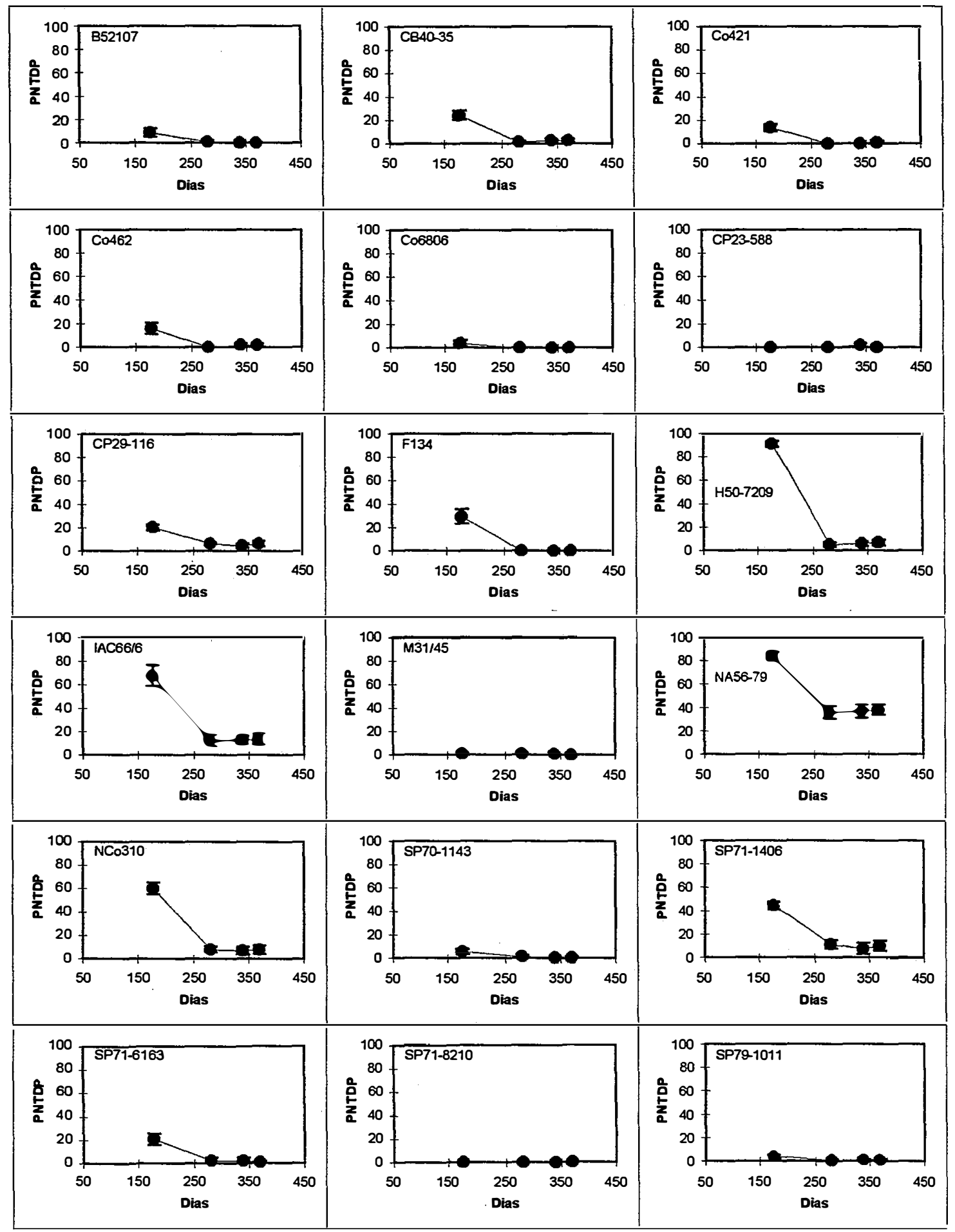


Anexo 20 - Porcentagem acumulada de perfilhos doentes por parcela (PAPDP) para as 18 variedades do experimento, durante a terceira soca.

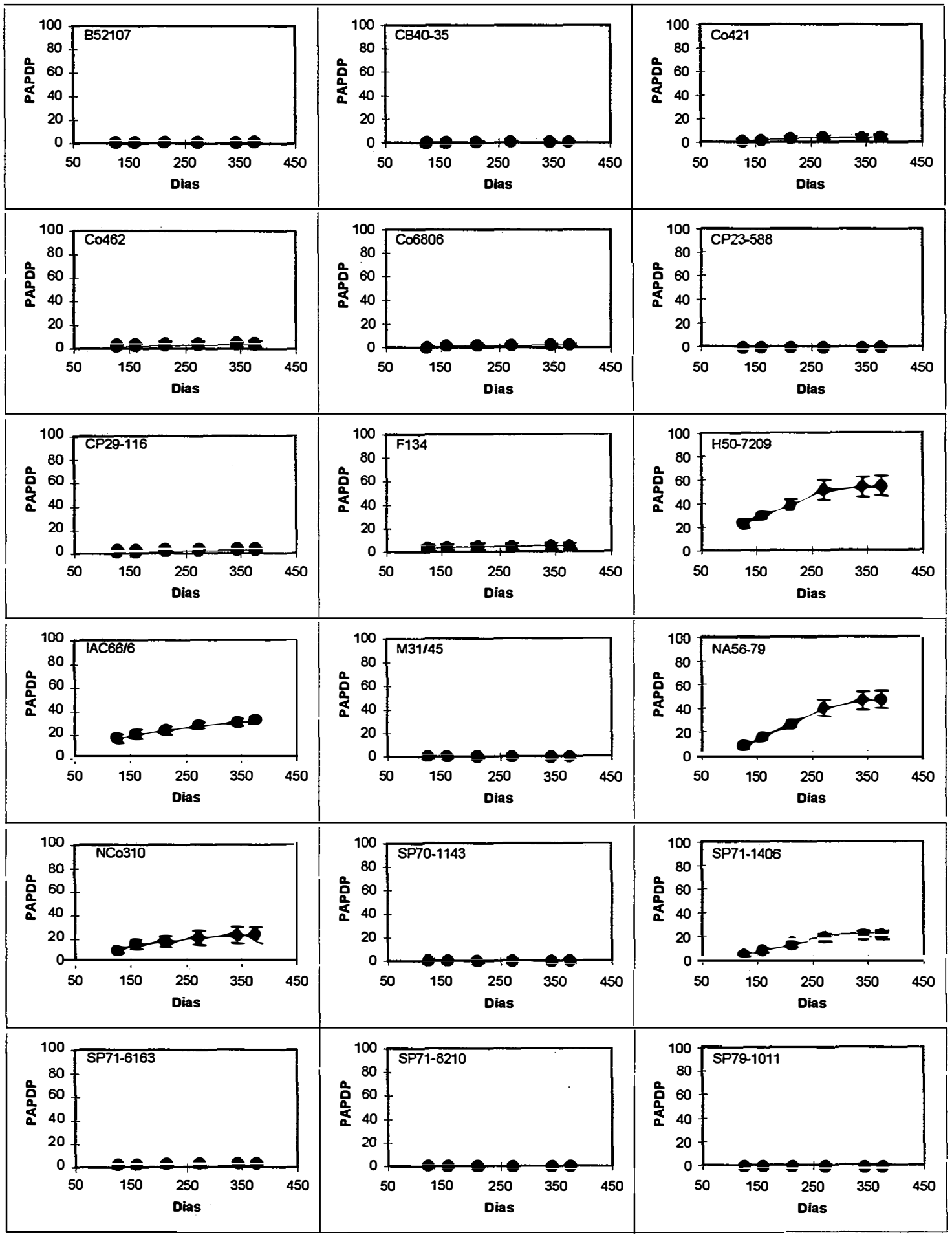


Anexo 21 - Porcentagem acumulada de perfilhos doentes por touceira (PAPDT) para as 18 variedades do experimento, durante a terceira soca.

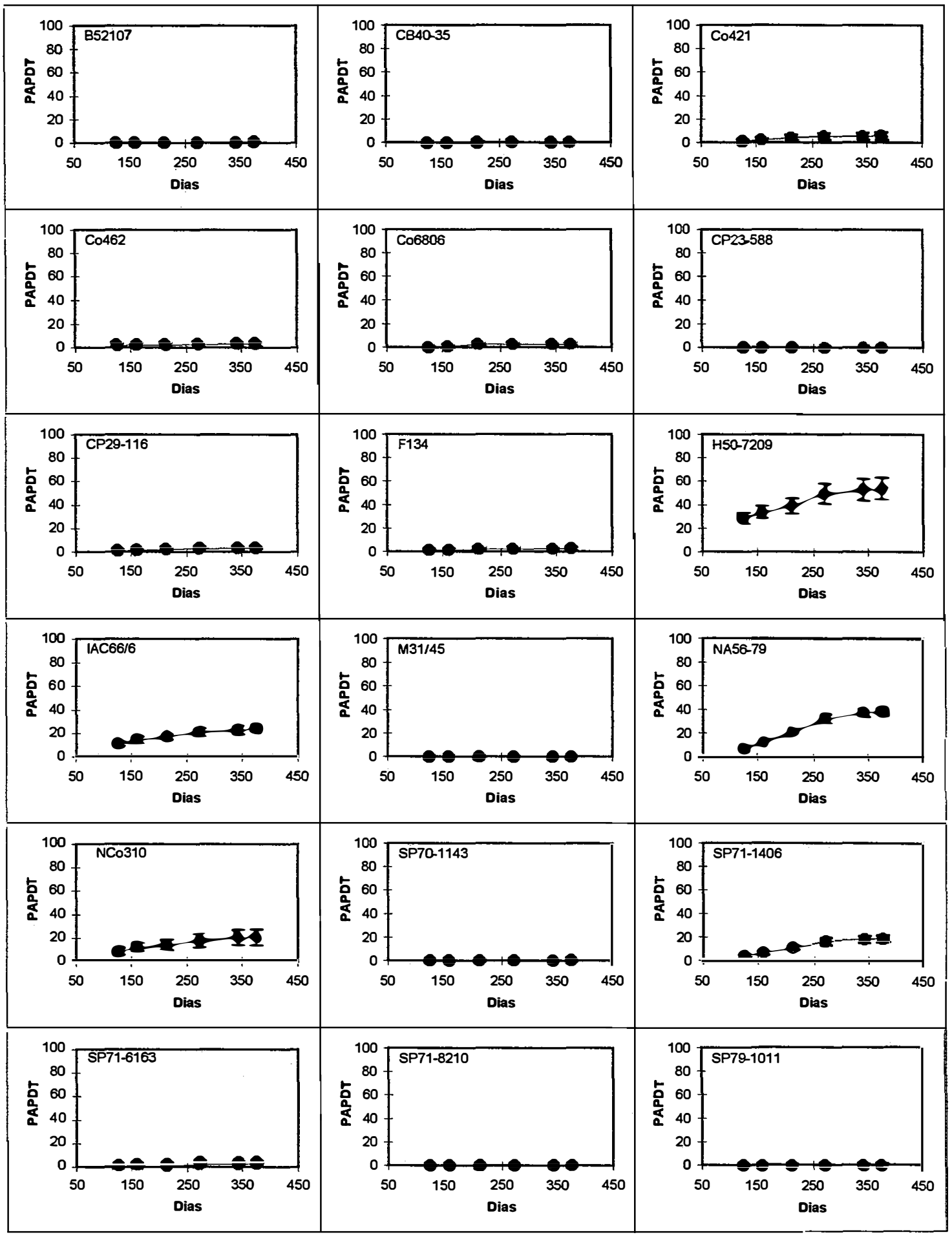


Anexo 22 - Porcentagem acumulada de touceiras doentes por parcela (PATDP) para as 18 variedades do experimento, durante a terceira soca.

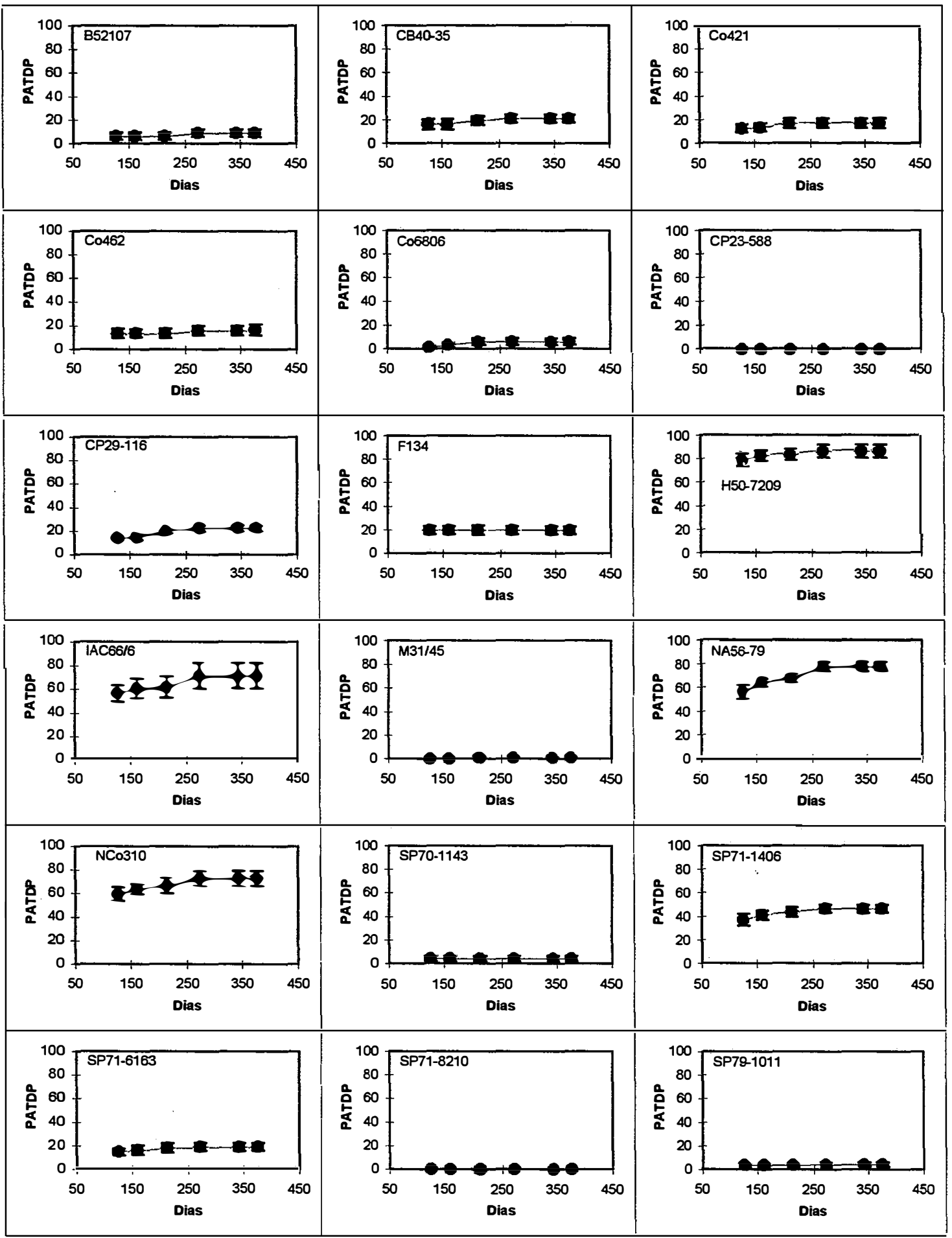


Anexo 23 - Porcentagem acumulada de touceiras mortas por parcela (PATMP) para as 18 variedades do experimento, durante a terceira soca.

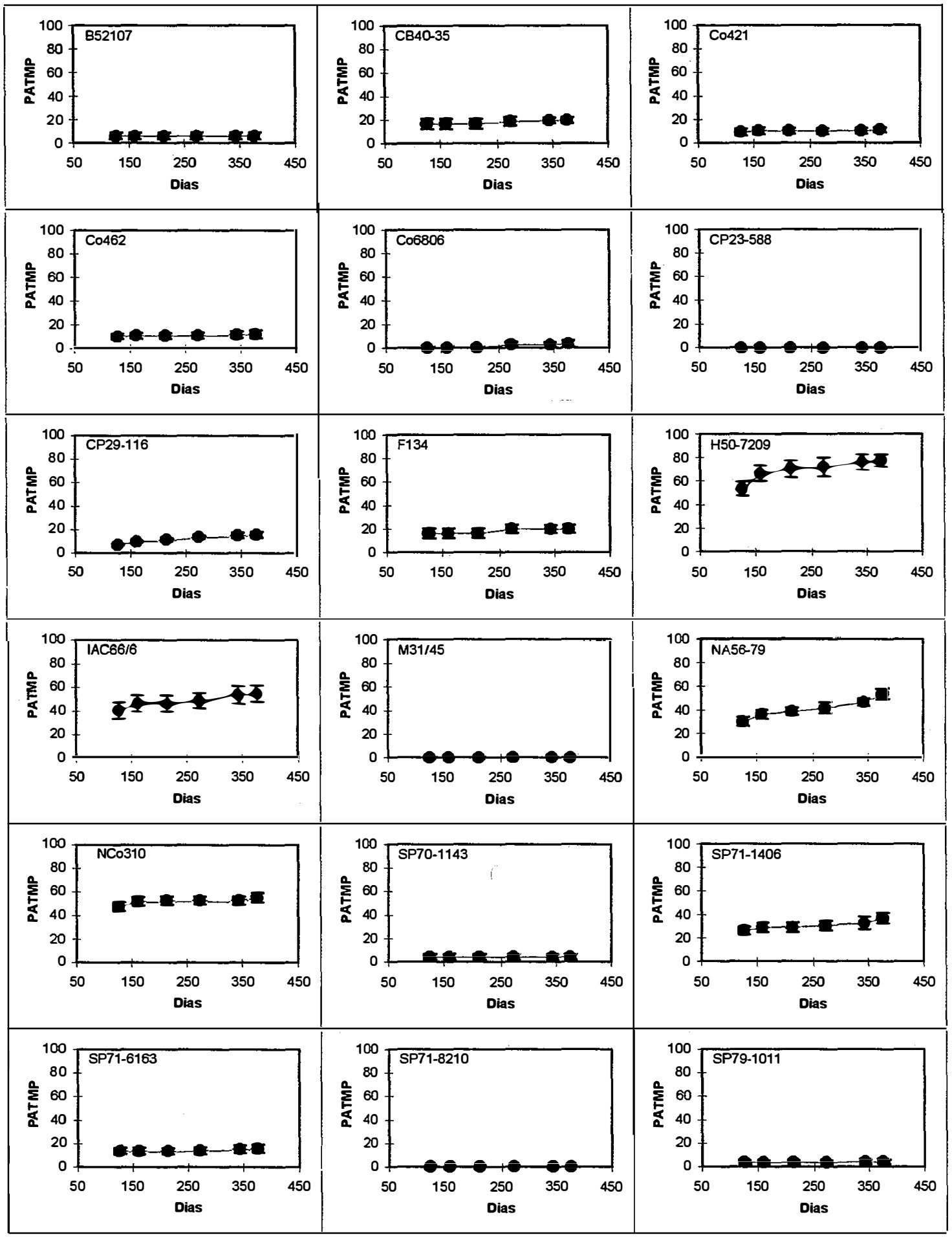


Anexo 24 - Porcentagem não acumulada de perfilhos doentes por parcela (PNPDP) para as 18 variedades do experimento, durante a terceira soca.

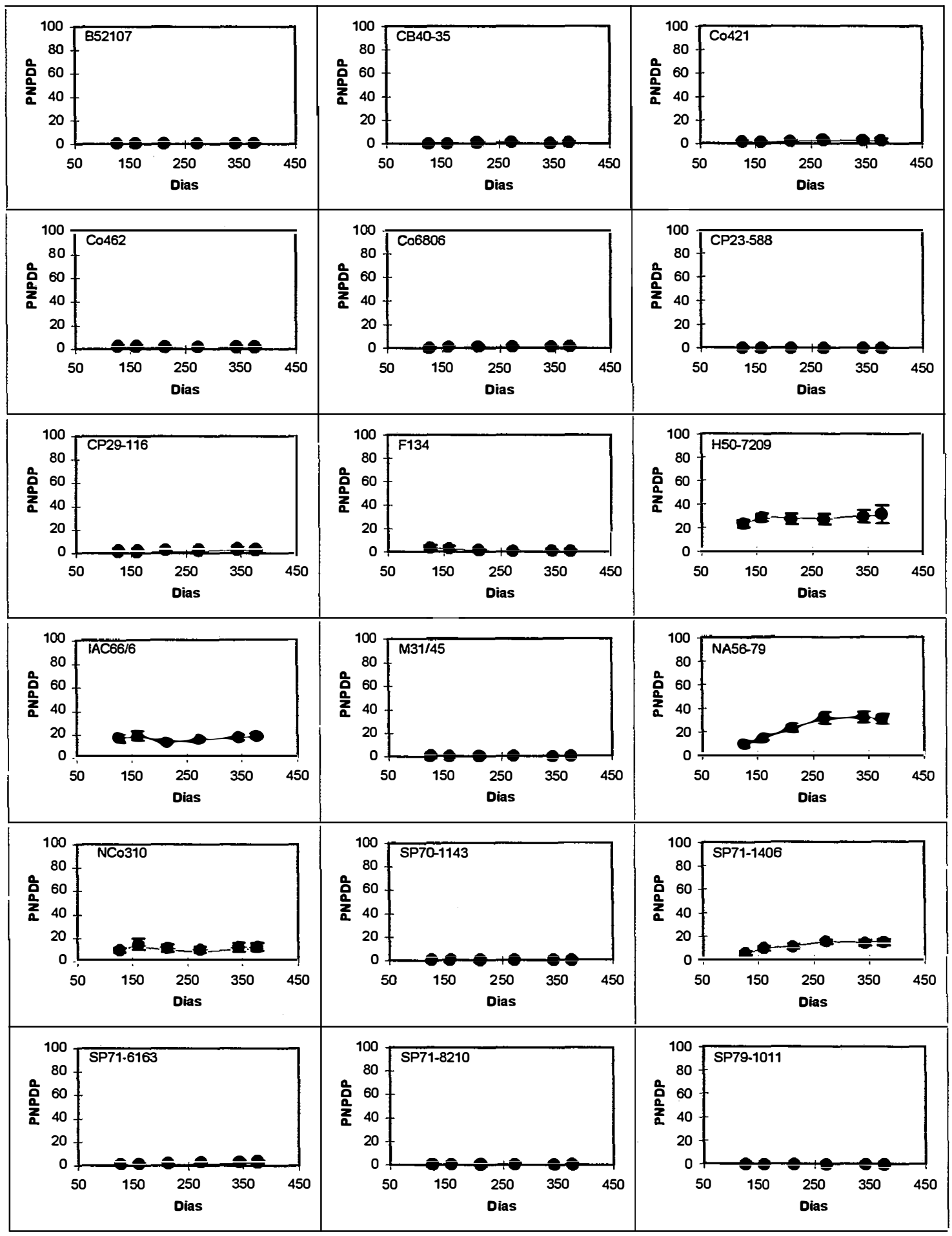


Anexo 25 - Porcentagem não acumulada de perfilhos doentes por touceira (PNPDT) para as 18 variedades do experimento, durante a terceira soca.

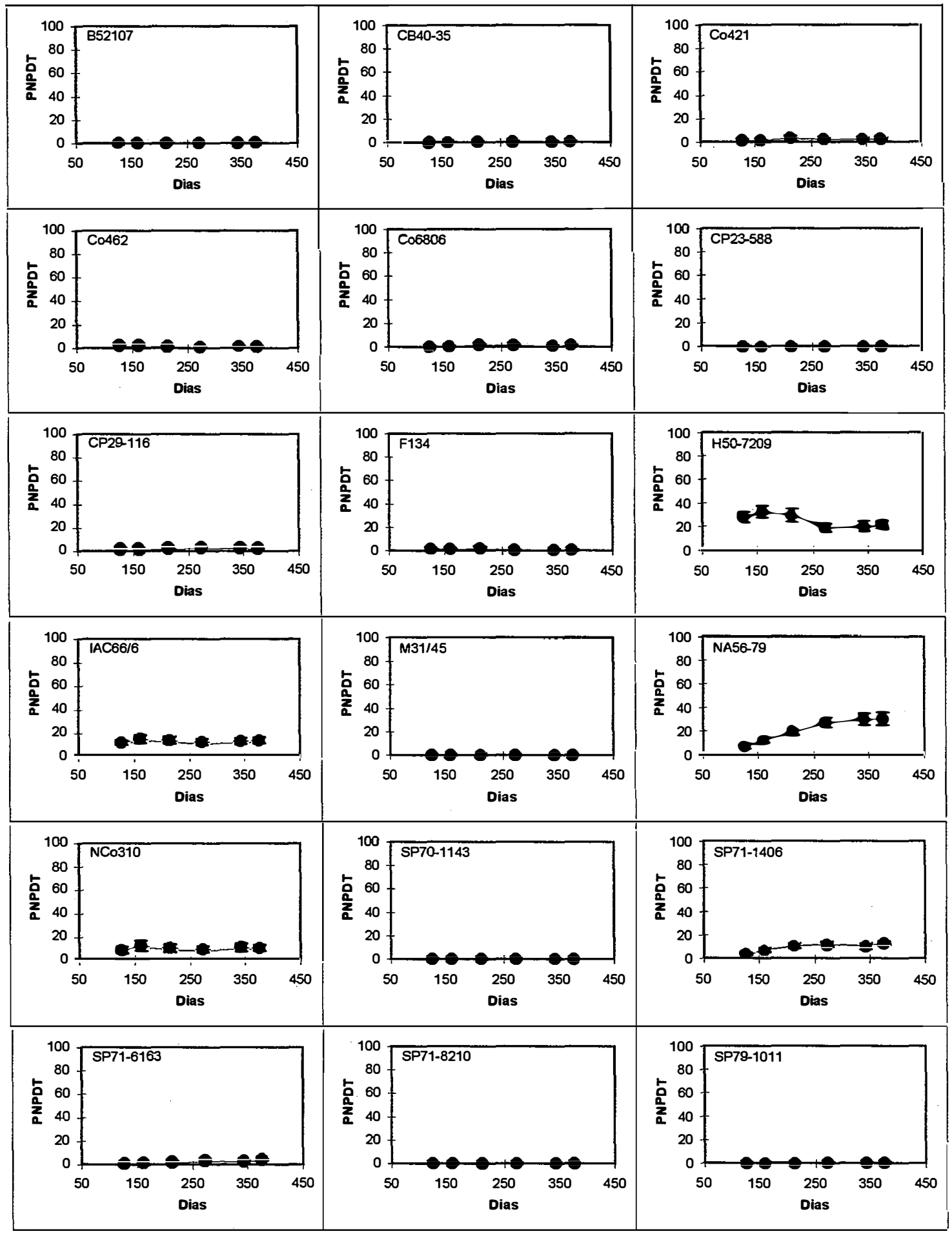


Anexo 26 - Porcentagem não acumulada de touceiras doentes por parcela (PNTDP) para as 18 variedades do experimento, durante a terceira soca.

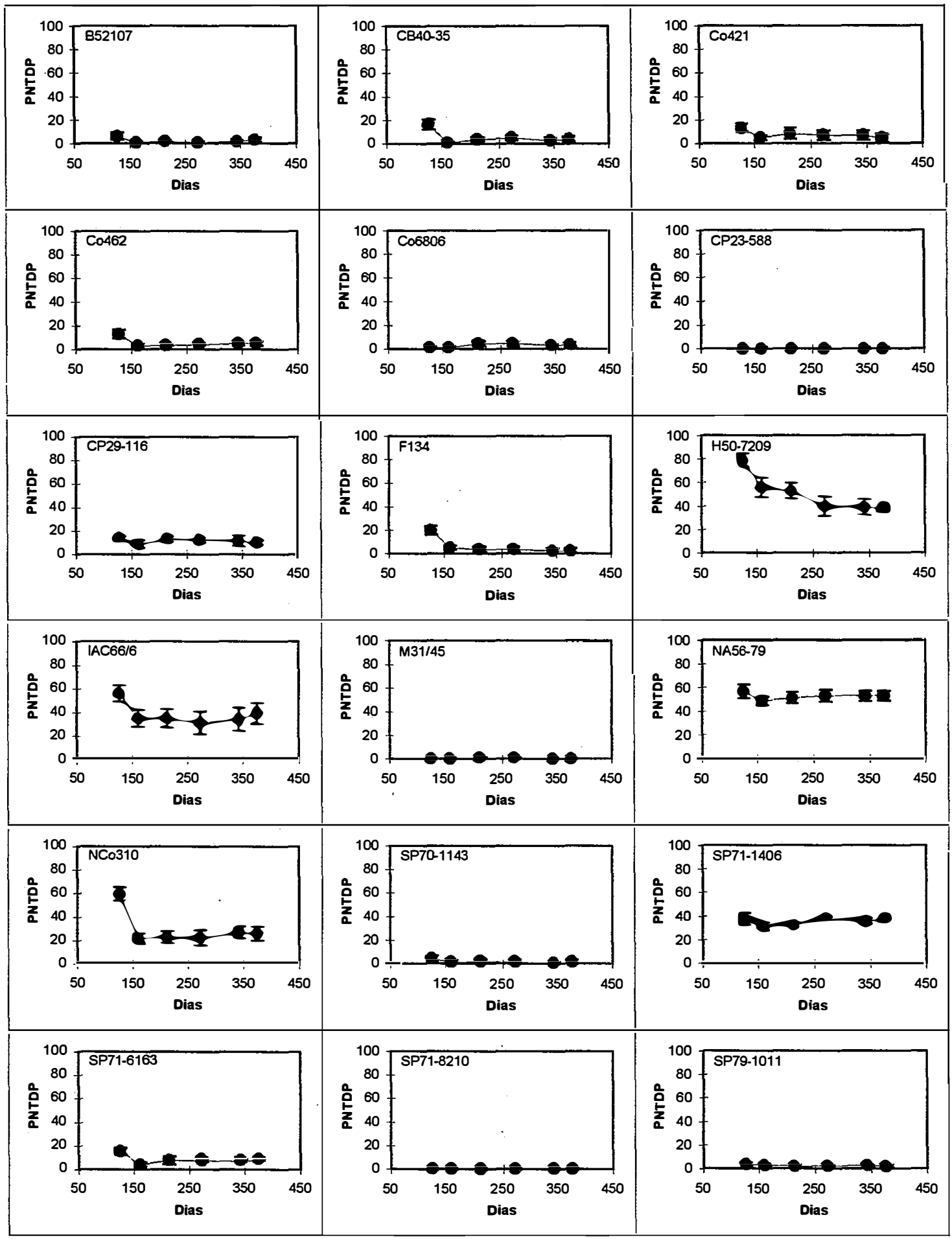

